\title{
Cytomegalovirus infection and transplant arteriosclerosis : an experimental study in rats
}

Citation for published version (APA):

Li, F. (1999). Cytomegalovirus infection and transplant arteriosclerosis : an experimental study in rats. [Doctoral Thesis, Maastricht University]. Universiteit Maastricht. https://doi.org/10.26481/dis.19991215fl

Document status and date:

Published: 01/01/1999

DOI:

10.26481/dis.19991215fl

Document Version:

Publisher's PDF, also known as Version of record

\section{Please check the document version of this publication:}

- A submitted manuscript is the version of the article upon submission and before peer-review. There can be important differences between the submitted version and the official published version of record.

People interested in the research are advised to contact the author for the final version of the publication, or visit the DOI to the publisher's website.

- The final author version and the galley proof are versions of the publication after peer review.

- The final published version features the final layout of the paper including the volume, issue and page numbers.

Link to publication

\footnotetext{
General rights rights.

- You may freely distribute the URL identifying the publication in the public portal. please follow below link for the End User Agreement:

www.umlib.nl/taverne-license

Take down policy

If you believe that this document breaches copyright please contact us at:

repository@maastrichtuniversity.nl

providing details and we will investigate your claim.
}

Copyright and moral rights for the publications made accessible in the public portal are retained by the authors and/or other copyright owners and it is a condition of accessing publications that users recognise and abide by the legal requirements associated with these

- Users may download and print one copy of any publication from the public portal for the purpose of private study or research.

- You may not further distribute the material or use it for any profit-making activity or commercial gain

If the publication is distributed under the terms of Article $25 \mathrm{fa}$ of the Dutch Copyright Act, indicated by the "Taverne" license above, 


\section{CYTOMEGALOVIRUS INFECTION AND TRANSPLANT ARTERIOSCLEROSIS}

AN EXPERIMENTAL STUDY IN RATS

FENGLING LI 
Lay out: Wil Mullers, Berg en Terblijt

Book production: Unigraphics, Maastricht 


\section{CYTOMEGALOVIRUS INFECTION AND TRANSPLANT ARTERIOSCLEROSIS}

\section{AN EXPERIMENTAL STUDY IN RATS}

Proefschrift

Ter verkrijging van de graad van doctor aan de Universiteit Maastricht, op gezag van de Rector Magnificus, Prof. dr. A.C. Nieuwenhuijzen Kruseman, volgens het besluit van het College van Decanen, in het openbaar te verdedigen op woensdag 15 december om 16.00 uur

door

Fengling Li

Geboren te Heilongjiang (China) op 6 november 1962 


\section{Promotor:}

Prof. dr. C.A. Bruggeman

\section{Beoordelingscommissie:}

Prof. dr. G. Kootstra, voorzitter

Prof. dr. M.J.A.P. Daemen

Prof. dr. M.C.E. van Dam-Mieras (Open Universiteit Heerlen)

Prof. dr. J.P. van Hooff

Dr. J. Rozing (Universiteit Groningen)

The investigations described in this thesis were carried out at the Department of Medical Microbiology, University of Maastricht, The Netherlands.

Financial support by the Netherlands Heart Foundation for the publication of this thesis is gratefully acknowledged. 


\section{Contents}

1. General introduction and aims of the study

2. Review of the literature

3. Correlation between the intensity of cytomegalovirus infection and the amount of perivasculitis in aortic allografts

4. Initial endothelial injury and cytomegalovirus infection accelerate the development of allograft arteriosclerosis

5. Cytomegalovirus infection enhances the perivascular inflammatory reaction in transplanted aortic allografts

6. Cytomegalovirus infection enhances the neointima formation in rat aortic allografts: effect of major histo-compatibility complex class I and class II antigen differences

7. Effects of cytomegalovirus infection and prolonged cold ischemia on chronic rejection of rat renal allografts. I. Functional and morphological changes.

8. Summary and general discussion

Acknowledgments

Curriculum Vitae 



\section{List of abbreviations}

CADI chronic allograft damage index

CI cold ischemia

CMV

cytomegalovirus

EGF

epidermal growth factor

ELAM

endothelial adhesion molecule

b-FGF

Gy basic-fibroblast growth factor

HCMV Gray

HLA

human cytomegalovirus

ICAM

IFN- $\gamma$

Ig

IL human leukocyte antigen intercellular adhesion molecule interferon-gamma immunoglobulin interleukin

iRCMV inactivated rat-specific cytomegalovirus

LFA $\mathrm{mAbs}$ lymphocyte function-associated antigen

MCMV monoclonal antibodies

MHC

PDGF

PMN

PFU

PSU mouse cytomegalovirus

major histocompatibility complex

platelet-derived growth factor

polymorphonuclear cell

plaque forming unit

RCMV rat-specific cytomegalovirus

SPF specific pathogen free

TAA

TBI transplantation-associated arteriosclerosis total body irradiation

TGF

TNF

transforming growth factor

tumor necrosis factor

TNN total number of nuclei vascular adhesion molecule 

GENERAL INTRODUCTION AND AIMS OF THE STUDY 
In chapter 5, CMV infection-induced upregulated expression of adhesion molecules, activation of inflammatory cells, neointima formation and perivasculitis are studied. By using the computeraided imagine analysis and immunohistochemistry, neointima area of aortic grafts, component of inflammatory infiltrates, and intensity of expression of adhesion molecules in the grafts were evaluated.

Chapter 6 focuses on the effect of MHC class I and class II mismatches on the development of TAA in CMV infected recipients of aortic allografts. The subsets of inflammatory cells, adhesion molecules, thickness of neointima and histologic changes of the aortic grafts at varying time points after transplantation are recorded and compared.

In chapter 7, a rat model of kidney transplantion is used to study whether CMV infection and prolonged cold ischemia have a synergistic effect on the progression of chronic rejection. Experimental parameters include chronic allograft damage index (CADI), infiltration of $\mathrm{CD}^{*}$, $\mathrm{CD}^{+} \mathrm{T}$ cells, monocytes/macrophages and natural killer cells, and expression of MHC class II antigens.

Chapter 8 consists of a general discussion and conclusions of this thesis. 



\section{REVIEW OF THE LITERATURE}




\section{TRANSPLANT ASSOCIATED ARTERIOSCLEROSIS(OR CHRONICREJECTION)}

The growing knowledge in the field of transplant immunology and the introduction of the new immunosuppressive agent cyclosporin in the late 1970's (1) dramatically improved the early results of organ transplantation, with significant reductions in early morbidity and mortality (2). As acute rejection episodes can be well controlled in the cyclosporin era, an increasing number of grafts survive. However, chronic rejection or TAA has become a major cause of diminished long-term survival of transplanted organs (3).

\section{The impact of transplant associated arteriosclerosis in organ transplantation}

To improve long-term survival of organ transplantation, the importance of TAA or chronic rejection has come to light $(4,5)$. Chronic rejection has been identified as the most important cause of graft failure after the first posttransplant year (6).

In cardiac allografts, TAA has emerged as a major factor affecting long-term cardiac allograft survival $(7,8)$. Cardiac TAA is the main cause of death one year after transplantation.year. In coronary angiography, the incidence of coronary arteriosclerosis is 6-18\% at 1 year, $23 \%$ at 2 years, and rises as high as $50 \%$ at 5 years $(9,10)$. Since angiography seems to be a less sensitive method for diagnosing chronic cardiac allograft rejection (11), and angiographic changes also appear later than histopathological changes detected by endomyocardial biopsy (12), the prevalence of chronic rejection is probably underestimated.

In renal allografts, the estimated prevalence of chronic rejection during the first five years has varied between $5-30 \%(5,12)$. After the first five years, the incidence has been found to be 13 $43 \%$ and account for $50-86 \%$ of graft failures $(6,13)$.

In liver allografts, although chronic rejection is less problem as compared to heart and kidney, chronic rejection is the major indication for liver retransplantation $(14,15)$.

\section{Major histocompatibility antigens}

Major histocompatibility (MHC) antigens were initially described as transplantation antigens because of their ability to induce graft rejection in a genetically nonidentical recipient (allograft rejection). MHC antigens are the principal targets of the immune response to allografts and $\mathrm{T}$ cell recognition of allo-MHC is the initial event which initiates allograft rejection. MHCincompatible tissues can induce uniquely strong primary immune responses, leading in vivo to allograft rejection and graft-versus-host disease, and in vitro to the mixed lymphocyte reaction. MHC is referred to human leukocyte antigen (HLA) in human, RT1 in rats and $\mathrm{H}-2$ in mice. The surface of all human cells express a series of molecules that recognized by other individuals as foreign antigens. The HLA system on lymphocytes and other tissues are extremely important in organ transplantation. They are encoded in humans by a segment of chromosome 6 known as MHC (16). 
HLA molecules play a crucial role in enabling the immune system to distinguish between 'self and 'nonself'. Normally, immune responses are restricted to invading microorganisms ('nonself') or infected cells ('nonself'). However, in transplantation, foreign HLA antigens on a graft are recognized as 'nonself' by the host's immune system and initiate a rejection response. The human MHC contains over 100 genes and is divided into three regions called class I, II and III (17). The class I region contains the classical loci HLA-A, B and C which code for products expressed on all nucleated cells in the body. The class II region includes the classical loci HLA-DR, DP and $\mathrm{DQ}$, the products of which are restricted to B lymphocytes, monocytes/macrophages, epidermal cells and follicular dendritic cells. However, MHC molecules can be induced by cytokines on T cells, endothelial, renal tubular and pancreatic beta cells (18). MHC antigen expressed on cells is controlled by cytokines: interferon- $\gamma$ and tumor necrosis factor (TNF) are powerful inducers of MHC antigen expression on many types of cells which would otherwise express MHC molecules only weakly. The class III region contains genes for complement components $\mathrm{C} 2, \mathrm{C} 4$ and factor B and also TNF. The principal classes important to the transplantation immunology are class I and class II.

HLA molecules are members of the immunoglobulin gene superfamily (16). Class I molecules consist of two chains, one of which is coded for by a gene within the MHC, and the other, of which $\beta_{2}$-microglobulin, is coded for by a gene on chromosome 15 . Class II molecules consist of two chains, both coded for by genes within the MHC. Class I molecules present antigenic peptides to CD8 positive cytotoxic T lymphocytes, while class II molecules present peptides to CD4 positive helper $\mathrm{T}$ lymphocytes (16).

\section{Allorecognition}

The discrimination of 'self' and 'nonself' allows vertebrate immune systems to recognize and defend against foreign substances such as bacteria, viruses and transplanted tissues or grafts from nonidentical individuals. The principal targets of the immune response to allografts are the MHC molecules themselves. T lymphocytes play a central role in the allorecognition and rejection (19). $\mathrm{T}$ cell recognition of allo-MHC is the primary and central event which initiates allograft rejection $(20,21)$. T cells possess a T cell antigen receptor on their cell surface. The function of the T cell antigen receptor is to bind to small fragments of antigen that are associated with MHC molecules on the surface of antigen-presenting cells (22). It is now clear that allorecognition involves a tripartite structure consisting of $\mathrm{T}$ cell antigen receptor, $\mathrm{MHC}$ molecules, and peptides bound in the groove of the MHC molecule (21). There are two distinct, but not necessarily mutually exclusive, pathways of allorecognition $(21,23)$, i.e. direct and indirect pathways.

In direct pathway, $\mathrm{T}$ cells via $\mathrm{T}$ cell antigen receptor recognize intact allo-MHC plus peptide complex on the surface of donor or stimulator cells. These peptides are usually derived from endogenous proteins, including minor histocompatibility or 'tissue-specific' antigens, or MHC peptides. It has been demonstrated that direct pathway of allorecognition is the principal contributor of strong $\mathrm{T}$ cell responses in acute rejection episodes $(24,25)$.

In indirect pathway, recipient $\mathrm{T}$ cells recognize processed allopeptides, predominantly allo-MHC peptides, presented by self MHC molecules on antigen-presenting cells of the recipient. It has 
been suggested that the indirect pathway of allorecognition, that is, T cell recognition of processed MHC allopeptides, may be the dominant pathway responsible for chronic rejection (25).

During allograft rejection, both allorecognition pathways seem to be effective. The direct pathway, where T cell receptors directly recognize intact allo-MHC on the surface of target cells, accounts for most of the cytotoxic $\mathrm{T}$ cell function. The indirect pathway in contrast, where $\mathrm{T}$ cell receptors recognize MHC allopeptides after processing and presentation by self antigenpresenting cells, may lead to the activation of T helper cells which secrete cytokines and provide the necessary signals for the growth and maturation of effector cytotoxic T lymphocytes and B cells leading to allograft rejection $(23,26)$.

\section{Morphological features of transplant associated arteriosclerosis}

Obliterative vascular changes, the characteristic of this process, constitute the morphological hallmark of TAA. It has been recognized that the proliferative vascular changes in chronic rejection have a similar appearance in all transplanted solid organs, being most prominent in the kidney and heart, whereas changes in the functional unit of the organ are dependent upon organ specificity (27).

Cardiac TAA affects the entire length of the vessels, not only the major vessels, but also the small penetrating intramyocardial branches (28). In cardiac allografts undergoing chronic rejection, concentric vascular intimal thickening is present together with interstitial fibrosis and mononuclear cell infiltration $(27,29,30)$. In addition, the perivascular inflammation and thinning of the vascular media occur. The intimal hyperplasia involves the proliferation of transformed smooth muscle cell (secretory type) and the infiltration of inflammatory cells such as macrophages and activated T lymphocytes $(27,29)$.

Although cardiac chronic rejection is commonly referred to as cardiac TAA, there are several differences between this process and traditional atherosclerosis. The latter demonstrates eccentric, focal and proximal lesions contain calcium, disrupt the internal elastic lamina, and develop over many years. Conversely, cardiac TAA is associated with concentric, diffuse, and distal lesions of the coronary vessels and branches. The internal elastic lamina is usually intact, calcification is rare. Furthermore, the development of intimal thickening is usually associated with a continuous low grade inflammation in the vascular wall of the allograft (7), and the disease tends to develop rapidly (28).

\section{Risk factors for transplant associated arteriosclerosis}

Although the exact pathogenesis of TAA remains to be established, several lines of experimental evidence suggest that immunologic mechanisms operating in a millieu of non-immunologic risk factors constitute the principal stimuli that result in endothelial injury and, consequently, neointima formation. Several risk factors contributing to the development of chronic rejection are reviewed in the following paragraphs. 


\section{Histoincompatibility}

The association between histocompatibility and the development of TAA is poorly understood and remains a matter of controversy (31). However, the characteristic findings of chronic rejection in allografts as compared with isografts support the role of histocompatibility in the process. HLA identical sibling renal transplant in the UNOS (United Network for Organ Sharing) Registry have a half-life of more than 20 years compared with less than 10 years in one haplotype mismatched, sibling transplants and seven to eight years in completely mismatched cadaveric donor transplant (32). Experimental studies have demonstrated that no or very minor chronic rejection changes are observed in syngeneic transplants in inbred animal models (33-35). In experimental heart transplantation, a more rapid onset of graft arteriosclerosis is observed after pretransplant immunization of the recipient with donor splenocytes (36). These data suggest that the degree of MHC matching has an important effect on long-term graft survival.

\section{Acute rejection episode}

The frequency and intensity of acute rejection episodes may be risk factors for chronic rejection $(37,38)$. Studies that have attempted to clarify the relation between acute rejection and cardiac TAA have produced conflicting results $(10,39-41)$. Study by Uretsky, et al. (42) has demonstrated that the occurrence of two or more major acute rejection episodes was associated with an increase in the prevalence and severity of cardiac TAA. Conversely, a study by Olivari et al (10) has shown that the incidence of cardiac TAA remained high despite a low incidence of acute allograft rejection. A third study demonstrated more specifically that the histologic type of acute allograft rejection may be associated with the development of cardiac TAA (43). Thus, cardiac transplant recipients in whom humoral or vascular rejection was found by endomyocardial biopsy had a greater risk of developing cardiac TAA. In kidney transplants, one study showed that the average half-life decreases from $12.8 \pm 2$ years for grafts with no acute rejection episodes to six years or less for grafts with multiple rejection episodes (44). However, in a study from Isoniemi et al. found no correlation between acute and chronic rejection was found (45). Experimental retransplantation models seems to underline the importance of early host immunoresponsiveness. In both rat cardiac and renal retransplantation experiments in which the allografts were retransplanted into syngeneic recipients. The histologic lesions associated with early chronic rejection were reversible if retransplantation was done within 12 weeks after allotransplantation for renal allografts and 40 days for cardiac allografts. If the allografts were retransplanted later than these times, the phenomenon progressed as in nonretransplanted allografts $(46,47)$. These data indicate that the early stages are reversible where as the later changes are irreversible with allogen-indepent factors becoming increasingly important.

\section{Endothelial injury}

The vascular endothelium plays an important role in the pathogenetic mechanisms of TAA (48, 49). The role of the vascular endothelial cells in maintaining the normal function of the vessel wall has long been recognized. Through its thromboresistant surface, the endothelial cell layer prevents the adherence of circulating leukocytes and platelets, prevents the activation of intrinsic and extrinsic coagulation systems, and forms a barrier against entry of blood constituents into the artery wall (50). The endothelial cell is both a target for and a mediator of injurious stimuli and 


\section{Chapter 2}

endothelial cells play an active role in inflammatory responses, immunity and thrombus formation $(51,52)$.

There are two types of endothelial injuries (53) that can lead to intimal proliferation: a denuding endothelial injury that removes the endothelial cell layer and will stimulate mechanisms that lead to platelet aggregation and release of growth factors, mainly platelet derived growth factor (PDGF); and a nondenuding endothelial injury (i.e., abnormal function of the endothelial cell with minimal or no morphologic changes) that induces changes in the permeability of the endothelial barrier (54). These changes allow an increase in the uptake of stimuli and immunoglobulins by the endothelial cell and moreover stimulate endothelial cells to produce growth factors and other mediators. The release of growth factors, particularly PDGF (a potent smooth muscle cell mitogen) by one or both endothelial injuries ultimately leads to myointimal proliferation of the vessel wall (53).

Preliminary evidence suggests that endothelial cells are the primary target of both humoral and cell-mediated immunity against cardiac allografts (55). Antibodies to endothelial cell antigens have been found in the serum of both renal (56) and cardiac allograft recipients (57). Moreover, endothelial cells express MHC class I and class II antigens (58), and anti-HLA antibodies are able to initiate endothelial cell injury leading to the development of cardiac TAA (59). In addition, up-regulated expression of the adhesion molecules, such as vascular adhesion molecule1 (VCAM-1), intercellular adhesion molecule-1 (ICAM-1) and endothelial adhesion molecule-1, on vascular endothelial cells are features observed in acutely or chronically rejecting allografts $(60,61)$.

\section{Hyperlipidemia}

Several studies have evaluated the changes in lipid levels that occur after cardiac transplantation $(62-64)$. The cause of posttransplant hyperlipidemia has not been determined with certainty. One important factor may be the obesity that develops after cardiac transplantation (65). In addition, the immunosuppressive agents used after heart transplantation may play a role in the development of posttransplant hyperlipidemia. Prednisone increases hepatic apolipoprotein B production and cyclosporine increases hepatic lipase activity and decreases lipoprotein lipase activity. Most clinical studies have suggested a relation between hypercholesterolemia and cardiac TAA $(66,67)$ and some, but not all, have demonstrated a relation between hypertriglyceridemia and cardiac TAA (68). Ventura et al (69) have shown that the degree of intimal thickening and the presence of plaque by intracoronary ultrasound correlated with hypercholesterolemia, hypertriglyceridemia, and an increased level of low-density lipoprotein cholesterol (68).

\section{Other non-immunologic risk factors}

Several other non-immunologic risk factors could contribute to the development of TAA. These include recipients characteristics (age, gender, obesity, hypertension, smoking, diabetes mellitus, or pretransplantation heart disease), donor characteristics (age, and gender), immunosuppressive agents, and nonimmune mechanisms of endothelial injury (ischemic time). Studies in rat allograft models have shown that cold ischemic injury accelerates the progression to chronic rejection and 
that this is mediated in part by $\mathrm{T}$ cells and macrophages (70). Several studies have suggested that recipient age and gender, donor age and gender, obesity, and donor ischemic time may have an impact on the development of TAA (71). In renal allografts, reduced functioning mass contributes to development of chronic graft dysfunction (72). Another factor is programmed cell death or apoptosis. There is clear evidence that apoptosis occurs in the allograft during rejection episodes (73). Some immunosuppressive drugs currently used in clinical transplantation medicine act in part through the introduction of apoptosis (74). Although the role of apoptosis in TAA is not known it is suggested that apoptosis contributes to the outcome after organtransplantation (75).

\section{CMV infection}

CMV infection is associated with increased morbidity and mortality in allograft recipients. There is strong clinical evidence showing that CMV infections play a role in the pathogenesis of cardiac TAA (76). Studies of endomyocardial biopsy specimens from human heart allografts show CMV-linked immune activation and typical subendothelial inflammation, which may contribute ultimately to graft arteriosclerosis and rejection (77). CMV nucleic acids have been identified in the coronary arteries of heart allografts with severe accelerated arteriosclerosis $(78,79)$. Acute vascular rejection in CMV-infected heart transplant recipients has also been associated with the subendothelial inflammatory response in large epicardial arteries (80).

\section{Cytomegalovirus (CMV) infection}

\section{Human cytomegalovirus}

Cytomegalovirus is a member of the herpesvirus family (81). The virus was first observed in the early 1900 s and received its name primarily based on the pathologic picture of the infected cells. Infected cells are usually large and swollen, with obvious nuclear and perinuclear inclusion bodies. The CMV genome is a linear double stranded DNA with a size of approximately $155 \mathrm{x}$ $10^{6}$ daltons (82). The virion contains a capsid surrounded by the tegument, an amorphous matrix, which is enclosed by a lipid bilayer membrane, the envelope. The virus enters the host cells using receptors on the envelope and incorporates its DNA into the nucleus. Once infected, the cellular machinery of the host is redirected to reproduce viral DNA and proteins, assembling and releasing new viral particles. The CMV genome encodes about 200 genes, some of which show sequence homologies with the human genome, e.g. class I and class II MHC molecules $(83,84)$.

CMVs are highly species specific DNA viruses. CMV is capable of infecting components of the vascular wall, in particular endothelial cells $(85,86)$, and smooth muscle cell (87). Like the other herpesviruses, once the host is infected, a latent infection is established $(88,89)$. The latent infection may reactivate under conditions of immunologic stress, such as immunosuppression $(90,91)$ and organ transplantation, resulting in replication of the virus but also through stimulation with allogeneic cells (92). In the solid organ transplant recipient, CMV disease may be the result of reactivation of the recipient's latent infection or through viral transmission from the donor organ (93). 
CMV's have envolved complex strategies to subvert recognition of immune effector cells. Human CMV (HCMV) expresses genes encoding transmembrane glycoproteins that interrupt the MHC class I pathway of antigen presentation (94 - 98).

\section{Rat CMV}

Rat cytomegalovirus (RCMV, Maastricht strain) was isolated from the salivary glands of wild Brown Norway rats (99). The nucleocapsid of RCMV has an overall diameter of $92-95 \mathrm{~nm}$, and is surrounded by an envelope of variable shape and size. The RCMV genome consists of a linear double stranded DNA with a molecule weight of $138 \times 10^{6}$ Daltons (100). The virus has homology with human CMV and expresses genes encoding G-coupled receptor homologs $(101,102,103)$.

RCMV appears to be species specific, since it is not capable to infect cells of human or mouse origin $(99,102)$. In vitro, the cytopathic effect of RCMV to rat embryonal fibroblast cells occurs 3 to 7 days after the infection. It is characterized by enlargement of the infected cell, a large nucleus and eosinophilic nuclear inclusions. In vivo, RCMV infection is mostly established by intraperitoneal injection of a virus suspension. Infection of laboratory rats resulted in virus replication in different organs during the first week after infection and in persistence in the salivary glands for several months $(105,106)$. CMV is able to infect or stimulate vascular cells such as endothelial cells and smooth muscle cells in experimental rat models in vivo and in vitro (107-110). Allogeneic immune responses are able to augment RCMV replication (111). Experiments have shown that CMV infection leads to expression of adhesion molecules and enhancement of adherence of leukocytes to endothelial cells $(107,109)$. In animal transplant models, CMV infection stimulates cell-mediated and humoral immune responses resulting in enhanced infiltration of leukocytes in the allografts and the smooth muscle cell proliferation (34). In addition, the virus infection caused subendothelial inflammation in the allograft vascular wall (112).

\section{CMV infection and transplant associated arteriosclerosis}

Cytomegalovirus infections are widespread among the normal population. Between $50 \%$ and $80 \%$ of the population is infected with HCMV (113), depending on the socio-economic state and age. The high prevalence of CMV infection in the general population has a great influence on organ transplantation and rejection, since all immunosuppresive agents produce a state of immunodeficiency required for graft implantation and survival. As such, they expose the recipient to an increased risk of viral infections, of which the most common is CMV.

Transplantation has become an established therapy for patients with end stage of organ failure. However, TAA or chronic rejection is the major cause of diminished long-term survival of transplanted organs (3). In cardiac allograft recipients the incidence of TAA is nearly $50 \%$ at 5 years after transplantation (9). The factors responsible for initiation and progression of TAA are not completely understood. Among others, TAA may be induced or accelerated by virus infections, such as CMV infection (114). CMV infection is associated with an increased incidence of graft failure (115) as well as with increased recipient mortality rates following transplantation (116). Despite recent improvements in immunosuppressive and antiviral 
therapies, CMV still remains a major cause of morbidity and mortality among heart allograft recipients $(117,118)$.

In the clinical setting, however, a direct causal relationship between CMV infection and disease or rejection is difficult to demonstrate because (acute) rejection often precedes CMV infection. On the other hand the increased risk of rejection after CMV infection may be related to the reduction in immunosuppression that is often part of the treatment approach for CMV infection. The hypothesis that CMV triggers graft rejection and that rejection favors CMV infection are not mutually exclusive (119).

In renal transplantation, $\mathrm{CMV}$ has been implicated to cause graft glomerulopathy $(120,121)$ and to trigger acute rejection (122-124). Within the introduction of ganciclovir the cilinical pattern of CMV disease has changed. CMV disease recurrence after successful treatment of the initial episode is common especially in liver and kidney-pancreas transplant recipients. $(125,126)$.

Risk factors for recurrence were a cadaver organ source and treatment for acute rejector (126) Experimental studies in rats demonstrated that CMV infection increased inflammation and expedited chronic rejection in renal allografts (127). Recently, Lautenschlager and coworkers showed that CMV prolonged and increased graft inflammation and accelerated chronic rejection of rat renal grafts under triple-drug treatment, which resembles the clinical situation (128). In renal allografts CMV infection increases collogen synthesis and development of fibrosis (129).

CMV has also been suggested to be associated to liver allograft rejection (130). CMV can be classified in four main genotypes on the basis of sequence analysis of the major envelope glycoprotein B (g B) (131). In a recent study of the laboratory of Chou (132) it was shown that CMV genotype $\mathrm{g} B$, was associated with a higher mean number of acute rejection episodes indicating that differences in strains of $\mathrm{CMV}$ are important factors in virus-induced pathology. In liver transplantation, an association between CMV infection and vanishing bile duct syndrome in hepatic allografts has been demonstrated (133) and CMV DNA in hepatocytes, bile ducts and vascular structures of liver transplants has been found in patients with vanishing bile duct syndrome (134).

CMV infection may be induced by viral reactivation of latent virus or primary infection at the time of transplantation. The former is more common but the latter generally is more severe. Primary infection is more likely to produce clinical symptoms than reactivation (135). Clinical manifestations of symptomatic CMV infection among immunosuppressed patients include undifferentiated fever, pneumonitis, hepatitis, retinitis, gastroenteritis, and a syndrome resembling infectious mononucleosis (136). Pneumonia is the most important short-term sequelae of CMV infection among organ transplant patients while retinitis and gastroenteritis are more common in AIDS patients (117). Clinical study by Grattan et al. (137) has revealed that CMV infections in cardiac transplant recipients constitute a risk factor for more frequent episodes of allograft rejection, more frequent and severe graft atherosclerosis, and a greater risk of death. The investigation by McDonald et al (76) in cardiac transplant patients demonstrated similar findings. Recently, several experimental studies have also reported that CMV infection is associated with 
the enhanced inflammatory response and arteriosclerotic changes in the transplanted heart (138) and aorta $(34,35)$ in rat model.

\section{Immunological response to $C M V$ infection}

Infection of an individual with CMV is followed by humoral and cellular immune responses. Following primary infection with CMV, production of immunoglobulin $(\mathrm{Ig}) \mathrm{G}(\mathrm{IgG})$ and $\mathrm{IgM}$ antibodies and cell mediated responses such as cytotoxic T cell responses, activation of NK cells and antibody-dependent killer cells occur (139). Virions and CMV infected cells are attacked by macrophages, polymorphonuclear granulocytes, monocytes and natural killer cells. These nonspecific cellular immune responses are of crucial importance in primary infections. Cellular immunity to $\mathrm{CMV}$ is also mediated both by cytotoxic $\mathrm{T}$ lymphocytes and $\mathrm{T}$ helper lymphocytes. CD8 $T$ cells have cytolytic activity on infected cells and recognize viral antigens presented by MHC class I molecules. CD4 T cells have regulatory functions and recognize viral antigens presented by MHC class II molecules.

The cellular immunity is supported by the humoral immunologic responses. After primary CMV infection, CMV-specific IgM, IgG, IgE and IgA antibodies can be detected (140). Antibody response to $\mathrm{CMV}$ is thought to be important for the elimination of free circulating virus particles. Antibodies mediate antibody-dependent cellular cytotoxicity and complement activation, and can enhance phagocytosis of infected cells. Beneficial effects of hyperimmune anti-CMV globulin for preventing active infections and for the treatment of CMV pneumonitis have been described (141).

Some experimental studies demonstrated that CMV infection can play a proinflammatory role and regulate cytokine production by inflammatory cells, and thus enhance inflammatory responses. The immediate early gene of $\mathrm{HCMV}$ is able to code for a protein that has sequence homology and immunologic cross reactivity with HLA-DR B-chain, thus possibly enhancing alloimmune responses to donor antigens (83). CMV also encodes a glycoprotein homologous with the heavy chain of MHC class I antigens that has the ability to bind the light chain of MHC class I molecule, i.e., to the $\beta_{2}$-microglobulin (84). In an animal experimental model, it has been demonstrated that CMV infection induces MHC class II molecule expression on rat heart microvascular endothelia in the absence of interferon- $\gamma(142)$. HCMV infection may up-regulate interleukin-1B (IL-1B) gene expression, leading to an increased production of $\mathrm{IL}-1$ by monocytes/macrophages (143). Studies by Geist et al demonstrated that the CMV IE gene products up-regulate endogenous IL-2 mRNA (144) and protein production, and up-regulate TNF promoter activity as well as endogenous TNF mRNA and protein production (145).

\section{Possible mechanisms of CMV-enhanced transplant associated arteriosclerosis}

Although the exact mechanisms that $\mathrm{CMV}$ infection involves in the development of cardiac TAA remains unclear, several mechanisms involved in the potential contribution of the virus to chronic rejection have been suggested. An alloimmune response to donor antigens may be enhanced by an immediate early gene of the virus which is able to code for a protein with sequence homology and immunological cross-reactivity with the HLA-DR $\beta$-chain (83). In addition, CMV encodes a glycoprotein homologous to the heavy chain of MHC class I antigen and capable of binding 
to the light chain of this molecule (84). Active infection is strongly associated with expression of VCAM-1 on capillary endothelial cell (146). Recent data show that CMV regulates the ICAM1 gene promotor in endothelial cells not via cellular cytokine production but rather by a direct effect of IE proteins of the virus (147). Its effects on leukocyte adhesion and infiltration may contribute to long-term changes in the graft. Cytokines associated with CMV infection and its inflammatory response may also increase endothelial cell damage and arteriosclerotic changes.

\section{Molecular mediators in transplantation and chronic rejection}

Cytokines, adhesion molecules and growth factors are critical in the response to injury, inflammation, infection and allograft rejection via the so-called "cytokine adhesion molecule cascade" $(148,149)$. Contact between circulating leukocytes and endothelial cell in the transplanted organ is thought to initiate the complex sequence of events culminating in acute rejection. Under normal conditions, contact between circulating leukocytes and vascular endothelium is random and dependent upon the flow characteristics in the vessel. However, in an allograft context, once endothelial cell are activated by surgical manipulation, ischemia, perfusion or storage, they express selectins and produce cytokines (IL-1, IL-6, TNF- $\alpha$ ) and growth factors, establishing a "cytokine gradient" near the vessel wall.

\section{Adhesion molecules}

A key event in many cell-cell interactions is adhesion, mediated by sets of adhesion molecules $(150,151)$. The selective binding of cells to other cells or to particular tissues or tissue components is a basic function of cell migration and recognition. Adhesion molecules responsible for such activities are also thought to influence the interaction between host leukocytes and graft endothelial cell, one of the initial events when a vascularized foreign organ is placed into the host circulation. The adhesion molecules involved in graft rejection have been divided into three major families: the selectin family, the integrin family and the Ig superfamily.

\section{Selectins}

These small proteins function as acute phase mediators, influencing the first contact between stimulated endothelial cell and leukocytes. After stimulation, activated vascular endothelial cell express P-selectin then E-selectin. P-selectin is thought to mediate the initial contact of endothelial cell and polymorphonuclear cells (PMN), whereas E-selectin may primarily interact with lymphocytes. L-selectin is expressed mainly on PMN, monocytes and some T cells interacting with its receptor on endothelial cell $(152,153)$.

\section{Integrins}

Integrins are $\alpha / \beta$ heterodimeric cell surface proteins comprised of two noncovalently linked polypeptide chains with extracellular and transmembrane segments and cytoplasmic tails. The extracellular domains bind to ligands which include complement components, extracellular matrix and other cell surface proteins. The cytoplasmatic domains interact with cytoskeletal components of cells, presumably to coordinate extracellular stimuli with cytoskeleton-dependent activities such as motility, shape change and phagocytosis (154). 


\section{Chapter 2}

\section{Immunoglobulin superfamily}

The adhesion molecules of the Ig superfamily, including ICAM-1, ICAM-2, ICAM-3, lymphocyte function-associated antigen-2, lymphocyte function-associated antigen -3 and VCAM-1, are found on a variety of cell types. Their expression tends to be increased by the proinflammatory cytokines interferon- $\gamma$, TNF, and IL-1. ICAM-1 and VCAM-1 are found on endothelial cells and are induced by IL-1 and TNF. ICAM-1 is also induced by interferon- $\gamma$. The ligand for ICAM-1 is lymphocyte function-associated antigen-1. The ligand for VCAM-1 is VLA-4, a B1 integrin found on leukocytes. The interactions of these molecules are involved in $\mathrm{T}$ cell proliferation and intracellular events supporting antigen binding to the $\mathrm{T}$ cell antigen receptor/CD3 complex. Members of this family are critical in various steps mediating host cell positioning, antigen recognition and activation (155). Studies in renal allografts have shown that both ICAM-1 and VCAM-1 are upregulated during acute and during chronic rejection $(156,157)$.

\section{Cytokines}

Cytokines and their receptors are protein mediators involved in inflammation and other host defenses. Elaborated by various cell populations, their synthesis is brief and self-limited. Cytokines generally lack membrane anchors and are not expressed as membrane proteins. Both cytokine mRNA and the cytokines themselves have short half-lives to permit fine regulation (158). Most cytokines are not stored in secretory granules but are synthesized when needed. Cytokine receptors are transmembrane proteins with an external ligand-binding domain and an intracytoplasmic signalling domain.

Helper T lymphocytes have been compartimentalized into Th- 1 and $\mathrm{Th}-2$ subsets based upon the cytokine profile they produce when stimulated and functional activities they promote. The Thltype response results in production of $\mathrm{LL}-2$, IFN- $\gamma$ and IL-3 shifting the immune response in the direction of a delayed hypersensivity or cell mediated immuneresponse. The Th- 2 response leads to production of $I L-4, I L-5, I L-6$ and $\mathrm{IL}-10$ and provide help for B cell stimulation and antibody production. Graft survival is prolonged by pretransplant transfusion of the graft recipient. While Th-1 like $T$ helper response has been postulated to promote graft rejection by some groups ( 159 , 160) other fail to detect such an effect (161). Study of the donor-specific cytokine production after heart transplantation revealed that during the first year after transplantantation especially Th-1 cytokines ( $\mathrm{IL}-1$ and IFN- $\gamma$ ) were produced and not Th-2 cytokines (IL-4 and IL-6). Thereafter the Th-1 cytokine levels normalized. IL- 6 was produced later after transplantation and is probably involved in smooth muscle cell proliferation (162).

\section{Interleukin 1 (IL-1)}

The major cellular source of IL-1 is the activated monocyte/macrophage. It is also secreted by $\mathrm{T}$ and $\mathrm{B}$ lymphocytes, and endothelial cells. IL-1 acts on monocytes/macrophages and vascular endothelial cells to induce synthesis of IL-6, IL-8 and IL-1 itself, cytokines which cause upregulation of adhesion molecules on endothelial cells. It also cause various cell types to synthesize enzymes that mediate production of prostaglandins, themselves involved in inflammation $(163,164)$. This seems critical in chronic rejection as IL-1 is mitogen for smooth muscle cells and fibroblasts (165). 


\section{Interleukin 2 (IL-2)}

$\mathrm{IL}-2$ is the major autocrine growth factor for T lymphocytes, causing their progression from the $\mathrm{G} 1$ to the $\mathrm{S}$ phase of the cell cycle. Its ambient concentration is an important determinant in the intensity of the immune responses. IL-2 stimulates the elaboration of other T cell-derived cytokines like interferon- $\gamma$. IL-2 also acts on human B cells as a growth factor and stimulates for antibody synthesis $(166,167)$. T lymphocytes can be activated by endothelial alloantigens. This activation results in the elaboration of IL-2 (168). Studies on the expression of cytokine messenger RNA after heart transplantation indicate that IL-2 (which is a T helper 1 cytokine) may promote cellular rejection while $\mathrm{IL}-10$ and possibly $\mathrm{IL}-4$ (which are Thelper 2 cytokines) may suppress graft rejection (169).

\section{Tumor necrosis factor (TNF)}

Activated monocytes/macrophages are the major source of TNF. It is also produced by T cells, activated NK cells, smooth muscle cell and epithelial cells $(170,171)$. Locally, it acts as a paracrine and autocrine mediator of leukocytes and endothelial cells, stimulating vascular endothelial cells, neutrophils, monocytes and lymphocytes to upregulate adhesion molecules including class I and class II MHC molecules and to produce cytokines such as IL-1, IL-6 and IL-8, and TNF itself. Many of TNF biologic actions are augmented by interferon- $\gamma$, which increases the numbers of TNF receptors; its synthesis is enhanced by $\mathrm{IL}-1, \mathrm{IL}-6$, and by TNF itself (172).

\section{Interferon- $\gamma$}

IL-2 secreting CD4 T cells and nearly all CD8 T cells are its primary cell source; its gene transcription is directly initiated as a consequence of antigen activation and is enhanced by $\mathrm{IL}-2$. Interferon- $\gamma$ is a potent activator of monocytes/macrophages and vascular endothelial cell, and promotes CD4 $\mathrm{T}$ cell adhesion and extravasation (173). It causes vascular endothelium, lymphoid tissues and other cell types to express class $\Pi \mathrm{MHC}$ molecules, amplifying the recognition phase of the immune response. It also acts directly on T and B lymphocytes to promote their differentiation, and activates NK cells and neutrophils (173). The importance of IFN- $\gamma$ to the developement of TAA was demonstrated using heterotopic vascularized murine cardiac allografts using IFN- $\gamma$-deficient mice or anti-IFN- $\gamma$ antibodies (174). More recently the same group demonstrated that a single episode of allogoneic injury suffices to induce graft arteriosclerosis. Using IFN- $\gamma$-deficient mice IFN- $\gamma$-deficient mice IFN- $\gamma$ was necessary for the development of TAA (175). Studies in allografts have shown the presence of a cellular infiltrate with predominantly Thl pattern during episodes of acute rejection. This is associated with an increase in the expression of IFN- $\gamma$ which is the Th1 cytokine $(176,177)$.

\section{Interleukin-6 (IL-6)}

IL-6 is synthesized by monocytes/macrophages, vascular endothelial cell, activated T cells, fibroblastes and other cells in response to IL-1 and TNF. It causes hepatocytes to produce plasma protein and induces IL-2 synthesis and IL-2 receptor expression on T cells. It is a important growth factor for activated B cells, including their differentiation. In the context of chronic 
rejection of renal grafts, IL-6 is a potent mitogen of glomerular mesangial cells, contributing to glomerulosclerosis (178).

\section{Growth factors}

\section{Platelet-derived growth factor (PDGF)}

PDGF is a potent smooth muscle cell chemoattractant and mitogen. It also induces a chemotactic response in fibroblasts, monocytes and neutrophils (179). PDGF is released by platelets in response to loss of vascular integrity. It is also produced by endothelial cells, smooth muscle cells and macrophages (180). It plays an important role in wound healing by inducing migration of leukocytes to injured tissue. It may be critical in the development of progressive vascular luminal obliteration in chronic rejection as it causes vasoconstriction, attracts leukocytes, locally stimulates cell proliferation and increases synthesis of collagen and elastin.

\section{Transforming growth factor $-\beta(T G F-\beta)$}

TGF- $B$ is secreted by monocytes/macrophages, activated T cells, endothelial cells and smooth muscle cell. Cyclosporine increases TGF- $B$ transcription in T lymphocytes (181). TGF- $B$ has the capacity to modulate immune responses and inflammation, augmenting certain immune responses while suppressing others (182). During progressive neointimal thickening after balloon denudation of artery, smooth muscle cells in the neointima produce TGF - $B$ suggesting that this molecule may have an important role as an endogenous growth regulatory factor (183). Moreover, TGF- $\beta$ bioactivity dramatically increases in cardiac allografts during chronic rejection (184). On the other hand, TGF- $\beta$ antagonizes many lymphocyte responses, including $T$ cell proliferation to polyclonal mitogens and maturation of $\mathrm{T}$ lymphocytes. It also inhibits endothelial cell and epithelial cell proliferation, and suppresses the ability of IL-1 to promote lymphocyte proliferation, and probably, immune responsiveness (185).

\section{Basic fibroblast growth factor (b-FGF)}

b-FGF is synthesized primarily by macrophages and endothelial cells. It may have a crucial role in the regulation of smooth muscle cell proliferation following vascular injury (186). It acts as a paracrine growth factor for fibroblasts, endothelial cells, and smooth muscle cells by promoting their proliferation.

\section{Endothelin-1}

Endothelin-1 was isolated for the first time in 1988 from the supernatant of cultured endothelial cells. It is peptide causing coronary vasocontriction (187). It has been shown to be elevated after organ transplantation $(188,189)$. Mononuclear cells, especially macrophages expres this peptide. In acutely rejecting renal allografts endothelin-1 is upregulated (190). The production of endothelin-1 is upregulated by IFN- $\gamma$ (191) suggesting that the interaction between T lymphocytes and endothelial cells is involved in its production during the rejection process. 


\section{References}

1. Calne RY, Rolles K, White DJG, Thiru S, Evans DB, McMaster P, Dunn DC, Craddock GN, Henderson RG, Aziz S, Lewis P. Cyclosporin A initially as the only immunosuppressant in 34 recipients of cadaveric organs: 32 kidneys, 2 pancreases and 2 livers. Lancet 1979;2:1033-1036.

2. Beveridge T. Clinical development of cyclosporin. Transpl Proc 1992;24 (Suppl 2):64-66.

3. Paul LC, Fellstrom B. Chronic vascular rejection of the treatment options emerged? Transplantation 1992;53:1169-1179.

4. Dennis MJS, Foster MC, Ryan JJ, Burden RP, Morgan AG, Blamey RW. The increasing importance of chronic rejection as a cause of renal allograft failure. Transplant Int 1989;2:214-217.

5. Foster MC, Wenham PW, Rowe PA, Burden RP, Morgan AG, Cotton RE, Blamey RW. The late results of renal transplantation and the importance of chronic rejection as a cause of graft loss. Ann R Coll Surg Engl 1989;71:44-47.

6. Paul LC. Chronic rejection of organ allografts: Magnitude of the problem. Transpl Proc 1993;25:2024-2025.

7. Billingham ME. Cardiac transplant atherosclerosis. Transpl Proc 1987;19 (4 Suppl 5):19-25.

8. Barnart GR, Pascoe EA, Mills AC, Szentpetery S, Eich DM, Mohanacumar T, Hastillo A, Thompson JA, Hess ML, Lower RR. Accelerated coronary arteriosclerosis in cardiac transplant recipients. Transplant Rev 1987;1:31-46.

9. Gao SZ, Alderman EL SJSJHSA. Accelerated coronary vascular disease in the heart transplant patient: coronary arteriographic findings. J Am Coll Cardiol 1988;12:334-340.

10. Olivari MT, Homans DC, Wilson RF, Kubo SH, Ring WS. Coronary artery disease in cardiac transplant patients receiving triple-drug immunosuppressive therapy. Circulation 1989;80:111-115.

11. Johnson DE, Gao SZ, Schroeder JS, DeCampli VM, Billingham ME. The spectrum of coronary artery pathologic findings in human cardiac allografts. J Heart Transplant 1989;8:349-359.

12. Hayry P, Isoniemi H, Yilmaz S, Mennander A, Lemström K, Risenen-Sokolowski A, Koskinen P, Ustinov J, Lautenschlager I, Taskinen E, Krogerus L, Aho P, Paavonen T. Chronic allograft rejection. Immunol Rev 1993;134:33-81.

13. Mahony JF. Long-term results and complications of transplantation: The kidney. Transpl Proc 1989;21:14331434.

14. Klintmalm GB, Nery JR, Husberg BS, Gonwa TA, Tillery GW. Rejection in liver transplantation. Hepatology 1989;10:978-985.

15. Quiroca J, Colina I, Demetris AJ, Starzl TE, van Thiel DH. Cause and timing of first allograft failure in orthotopic liver transplantation: a study of 177 consecutive patients. Hepatology 1991;14:1054-1062.

16. Trowsdale J, Owen MJ. Major histocompatibility complex antigens. In: Lachmann PJ, Peters K, Rosen RS, Walport MJ, eds. Clinical Aspects of Immunology. 5th edn Ed. Oxford: Blackwell Scientific Publications, 1993:171-197.

17. Campbell DC, Trowsdale J. Map of the human MHC. Immunology Today 1993;14:349-352.

18. Powis SH, Trowsdale J. Major and minor histocompatibility antigens. In: Thomson AW, Catto GRD, eds. Immunology of Renal Transplantatione. London: Edward Amold, 1993:3-26.

19. Colvin RB. Cellular and molecular mechanisms of allograft rejection. Ann Rev of Medicine 1990;41:361-375.

20. Krensky AM, Weiss A, Crabtree G, avis M, arham P. Mechanisms of disease: T lymphocyte-antigen interactions in transplant rejection. N Engl J Med 1990;322:510-517.

21. Sayegh $\mathrm{MH}$, Watschinger B, Carpenter CB. Mechanisms of $T$ cell recognition of alloantigen: The role of peptides. Transplantation 1994;57:1295-1302.

22. Unanue ER, Allen PM. The basis for the immunoregulatory role of macrophages and other accessory cells. Science 1987;236:551-557.

23. Shoskes $\mathrm{AD}$, Wood $\mathrm{JK}$. Indirect presentation of $\mathrm{MHC}$ antigens in transplantation. Immunology Today 1994; 15:32-38.

24. Rosenberg AS, Mizuochi T, Sharrow SO, Singer A. Phenotype, specificity, and function of T cell subsets and T cell interactions involved in skin allograft rejection. J Exp Med 1987;165:1296-1315.

25. Liu Z, Sun YK, Xi YP, Maffei A, Reed E, Harris P, Suciu-Foca N. Contribution of direct and indirect recognition pathways to T cell alloreactivity, J Exp Med 1993;177:1643-1650. 
26. Watschinger B, Gallon L, Carpenter CB, Sayegh MH. Mechanisms of allorecognition: in vivo primed T-cells recognize major histocompatibility complex polymorphisms presented as peptides by responder antigenpresenting cells. Transplantation 1994;57:572

27. Demetris AJ, Zerbe T, Banner B. Morphology of solid organ allograft arteriopathy: Identification of proliferating intimal cell populations. Transpl Proc 1989;21:3667-3669.

28. Billingham ME. Histopathology of graft coronary disease. J Heart Lung Transplant 1992;3:538-544.

29. Billingham ME. Graft coronary disease: The lesions and the patients. Transpl Proc 1989;21:3665-3666.

30. Uys C, Rose A. Pathologic findings in long-term cardiac transplants. Arch Pathol Lab Med 1984;108:112116.

31. Costanzo-Nordin MR. Cardiac allograft vasculopathy: relationship with acute cellular rejection and histocompatibility. J Heart Lung Transplant 1992;11:S90-S104

32. Terasaki PI, Cecka JM, Gjertson DW, Hao Y, Takemoto S, Cohn M. A ten year prediction for kidney transplant survival. In: Terasaki PI, Cecka JM, eds. Clinical Transplants. Los Angeles: UCLA Tissue Typing Laboratory, 1992:501-512.

33. Cramer DV, Qian S, Harnaha J, Chapman FA, Estes LW, Starzl TE, Makowka L. Cardiac transplantation in the rat. I. The effect of histocompatibility differences on graft arteriosclerosis. Transplantation 1989;47:414419.

34. Lemstrŏm KB, Bruning JH, Bruggeman CA, Lautenschlager IT, Hayry PJ. Cytomegalovirus infection enhances smooth muscle cell proliferation and intimal thickening of rat aortic allografts. J Clin Invest 1993;92:549-558.

35. Bruning JH, Persoons M, Lemström K, Stals FS, Clerq de E, Bruggeman CA. Enhancement of transplantationassociated atherosclerosis by CMV, which can be prevented by anti-viral therapy in the form of HPMPC. Transplant Int 1994;7(Suppl 1):S365-S370

36. Cramer DV, Chapman FA, Wu GD, Harnaha JB, Qian SQ, Makowka L. Cardiac transplantation in the rat. II. Alteration of the severity of donor graft arteriosclerosis by modulation of the host immune response. Transplantation 1990;50:554-558.

37. Basadonna GP, Matas AJ, Gillingham KJ, Payne WD, Dunn DL, Sutherland DE, Gores PF, Gruessner RW, Najarian JS. Early versus late acute renal allograft rejection: impact on chronic rejection. Transplantation 1993;55:993-995.

38. Tesi RJ, Elkhammas EA, Henry ML, Davies EA, Salazar A, Ferguson RM. Acute rejection episodes: best predictor of long-term primary cadaveric renal transplant survival. Transpl Proc 1993;25:901-902.

39. Narrod J, Kormos R, Hardesty R, Ladowsky J, Griffith B. Acute rejection and coronary artery disease in longterm survivors of heart transplantation. J Heart Lung Transplant 1989;5:418-421.

40. Schutz A, Kemkes BM, Kugler C, Angermann C, Schad N, RienmullerR, Fritsch S, Anthuber M, Neumaier $\mathrm{P}$, Gokel JM. The influence of rejection episodes on the development of coronary artery disease after heart transplantation. Eur J Cardiothorac Surg 1990;4:300-307.

41. Pahl E, Fricker I, Armitage J, Griffith BP, Taylor S, Uretsky BF, Beerman LB, Zuberbuhler JR. Coronary arteriosclerosis in pediatric heart transplant survivors: limitation of long-term survival. J Pediatr 1990;2:177183.

42. Uretsky BF, Murali S, Reddy PS, Rabin B, Griffith BP, Hardesty RL, Trento A, Bahnson HT. Development of coronary artery disease in cardiac transplant recipients receiving immunosuppressive therapy with cyclosporine and prednisone. Circulation 1987;76:827-834.

43. Hammond EH, Yowell RL, Price GD, Menloove RL, Olsen SL, O'Connell JB, Bristow MR, Doty DB, Millar RC, Karwande SV, Jones KW, Gay WAJ, Renlund DG. Vascular rejection and its relationship to allograft coronary artery disease. J Heart Lung Transplant 1992;11:S111-S119

44. Matas AJ, Gillingham KJ, Payne WD, Najarian JS. The impact of an acute rejection episode on long-term renal allograft survival (t1/2). Transplantation 1994;57:857-859.

45. Isoniemi H, Nurminen M, Tikkanen MJ, Vossen RCRM, Krogerus L, Ahonen J, Eklund B, Hockerstedt K, Salmela K, Hayry P. Risk factors predicting chronic rejection of renal allografts. Transplantation 1994;57:6872.

46. Forbes $\mathrm{RD}$, Zheng $\mathrm{SX}$, Gomersall $\mathrm{M}$, et al. Irreversible chronic vascular rejection occurs only after development of advanced allograft vasculopathy - A comparative study of a rat cardiac allograft model using a retransplantation protocol. Transplantation 1997;63:743. 
47. Tullius SG, Hancock WW, Heemann U, et al. Reversibility of chronic renal allograft rejection. Clinical effect of time after transplantation suggests both host immune dependent and independent phases of progressive injury. Transplantation 1994;58:93

48. Fellstrom B, Larsson E. Pathogenesis and treatment perspectives of chronic graft rejection (CVR). Immunol Rev 1993;134:83-98.

49. Foegh ML. Chronic rejection - graft arteriosclerosis. Transpl Proc 1990;22:119-122.

50. Huttner I, Gabbiani G. Vascular endothelium: recent advances and unanswered questions. Lab Invest 1982;47:409-411.

51. Vane JR, Aengard EE, Botting RM. Mechanisms of disease: Regulatory functions of the vascular endothelium. N Engl J Med 1990;323:27-37.

52. Borsum T. Biochemical properties of vascular endothelial cells. Virchows Arch B cell Pathol 1991;60:279286.

53. Ross R. Mechanisms of disease-Atherosclerosis-An inflammatory disease. N Engl J Med 1999;340; 2:115126.

54. Reidy MA, Schwartz SM. Endothelial injury and regeneration: IV: endotoxin-a nondenuding injury to aortic endothelium. Lab Invest 1983;48:25-34.

55. Chomette G, Auriol M, Cabrol C. Chronic rejection in human heart transplantation. J Heart Lung Transplant 1988;7:292-297.

56. Cerrilli J, Brasile L, Galouzis T, Lempert N, Clarke J. The vascular endothelial cell antigen system. Transplantation 1985;39:286-289.

57. Brasile L, Zerbe T, Rabin B, Clarke J, Abrams A, Cerrilli J. Identification of the antibody to vascular endothelial cells in patients undergoing cardiac transplantation. Transplantation 1985;40:672-675.

58. Rabin BS, Griffith BP, Hardesty RL. Vascular endothelial cell HLA-DR antigen and myocyte necrosis in human allograft rejection. J Heart Lung Transplant 1985;4:293-295.

59. Rose EA, Smith CR, Petrossian GA, Barr ML, Reemtsma K. Humoral immune responses after cardiac transplantation: correlation with fatal rejection and graft atherosclerosis. Surgery 1989;106:203-207.

60. Hancock WH, Whitley DW, Tullius SG, Heemann UW, Wasowska B, Baldwin III WM, Tilney NL. Cytokines, adhesion molecules, and the pathogenesis of chronic rejection of rat renal allogrfats. Transplantation 1993;56:643-650.

61. Mampaso F, Sanchez-Madrid F, Marcen R, Molina A, Pascual J, Bricio T, Martin A, Alvarez V. Expression of adhesion molecules in allograft renal dysfunction. A distinct diagnostic pattern in rejection and cyclosporine nephrotoxicity. Transplantation 1993;56:687-691.

62. Grady KL, Costanzo-Nordin MR, Herold LS, Sriniavasan S, Pifarre R. Obesity and hyperiipidemia after heart transplantation. J Heart Lung Transplant 1991;10:449-454.

63. Stamler JS, Vaughan DE, Rudd MA, Mudge GH, Kirshenbaum J, Young P, Alexander RW, Loscalzo J. Frequency of hypercholesterolemia after cardiac transplantation. Am J Cardiol 1988;62:1268-1272.

64. Farmer JA, Ballantyne CM, Frazier OH, Radovancevic B, Payton-Ross C, Patsch W, Morrisett JD, Gotto AMJ, Young JB. Lipoprotein(a) and apolipoprotein changes after cardiac transplantation. J Am Coll Cardiol 1991;18:926-930.

65. Keogh A, Simons L, Spratt P, Esmore D, Chang V, Hickie J, Baron D. Hyperlipidemia after heart transplantation. J Heart Transplant 1988;7:171-175.

66. Winters GL, Kendall TJ, Radio SJ, Wilson JE, Costanzo-Nordin MR, Switzer BL, Remmenga JA, McManus BM. Posttransplant obesity and hyperlipidemia: major predictors of serverity of coronary arteriopathy in failed human heart allografts. J Heart Lung Transplant 1990;9:364-371.

67. Eich D, Thompson JA, Daijin K, Hastillo A, Lower R, Katz S, Katz M, Hess ML. Hypercholesterolemia in long-term survivors of heart transplantation: an early marker of accelerated coronary artery disease. J Heart Lung Transplant 1991;10:45-49.

68. Escobar A, Ventura HO, Stapleton DD, Mehra MR, Ramee SR, Collins TC, Jain SP, White CJ. Cardiac allograft vasculopathy assessed by intravascular ultrasonography and non-immunologic risk factors. Am J Cardiol 1994;74:1042-1046.

69. Ventura HO, Mehra MR, Smart FW, Stapleton DD. Cardiac allograft vasculopathy: Current concepts. Am Heart Journal 1995;129:791-798. 
70. Knight RJ, Dikman S, Liu H, Martinelli, GP. Cold ischemic injury accelerates the progression to chronic rejection in a rat cardiac allograft model. Transplantation 1997;64:1102-1107.

71. Johnson MR. Transplant coronary disease: nonimmunologic risk factors. J Heart Lung Transplant 1992;11:S124-S132

72. Heemann UW, Azuma H, Tullius SG, Mackenzie H, Brenner BM, Tilney NL. The contribution of reduced functioning mass to chronic kidney allograft dysfunction in rats. Transplantation 1994;58:1317-1322.

73. Larsson CP, Alexander DZ, Hendrix R, Ritchie SC, Pearson T. Fas-mediated cytotoxicity: an immunoeffector or immunoregulatory pathway in T cell-mediated immune responses? Transplantation 1995;60:221.

74. Kabelitz D. Apoptosis, graft rejection, and transplantation tolerance. Transplantation 1998;65:869-875.

75. Akyürek LM, Johnsson C, Lange D, Georgii-Hemming P, Larsson E, Fellström BC, Funa K, Tufveson G. Tolerance induction ameliorates allograft vasculopathy in rat aortic transplants influence of Fas-mediated apoptosis. J Clin Invest 1998;101:2889-2899.

76. McDonald K, Rector TS, Braunlin EA, Kubo SH, Olivari MT. Association of coronary artery disease in cardiac transplant recipients with cytomegalovirus infection. Am J Cardiac 1989;64:359-362.

77. Koskinen PK, Krogerus LA, Nieminen MS, Mattila SP, Hayry PJ, Lautenschlager IT. Cytomegalovirus infection-associated generalized immune activation in heart allograft recipients: a study of cellular events in peripheral blood and endomyocardial biopsy specimens. Transplant Int 1994;7:163-171.

78. Hruban RT, Wu TC, Beschorner WE, Cameron DE, Ambinder RF, Baumgartner WA, Hutchins GM, Reitz BA. Cytomegalovirus nucleic acids in allografted hearts. Hum Pathol 1990;21:981-983.

79. Wu TC, Hruban RT, Ambinder RF, Pizzorno M, Cameron DE, Baumgartner WA, Reitz BA, Haywaed GS, Hutchins GM. Demonstration of cytomegalovirus nucleic acids in the coronary arteries of transplanted heart. Am J Pathol 1992;140:739-747.

80. Normann SJ, Salomon DR, Leelachaikul P, Khan SR, Staples ED, Alexander JA, Mayfield WR, Knauf DG, Sadier LA, Selman S. Acute vascular rejection of the coronary arteries in human heart transplantation: pathology and correlations with immunosuppression and cytomegalovirus infection. J Heart Lung Transplant 1991;10:674-687.

81. Ho M. Cytomegalovirus: Biology and Infection. New York: Plenum Medical Book Co, 1982:1-309.

82. Stinski M. Molecular biology of cytomegalovirus replication. In: Ho M, ed. Cytomegalovirus: biology and infection. New York: Plenum Press, 1991:7-35.

83. Fujinami RS, Nelson JA, Walker L, Oldstone MBAL. Sequence homology and immunologic cross reactivity of human cytomegalovirus with HLA-DR beta chain: a means for graft rejection and immunosuppression. J Virol 1988;62:100-106.

84. Beck S, Barrel BG. Human cytomegalovirus encodes a glycoprotein homologous to MHC class I antigens. Nature 1988;331:269-272.

85. Span AHM, Frederik PM, Grauls G, van Boven CPA, Bruggeman CA. CMV induced vascular injury: an electron-microscopic study in the rat. In Vivo 1993;7:567-574.

86. Smiley ML, Mar E-C, Huang E-S. Cytomegalovirus infection and viral-induced transformation of human endothelial cells. J Med Virol 1988;25:213-226.

87. Tumilowicz JJ, Gawlik ME, Bowell PP, Trentin JJ. Replication of cytomegalovirus in human arterial smooth muscle cells. J Virol 1985;56:839-845.

88. Bruggeman CA. Reactivation of latent CMV in the rat. Transpl Proc 1991;23:22-24.

89. Fajac A, Vidaud M, Lebargy F, Stephan F, Ricci S, Geslin P, Goossens M, Bernaudin JF. Evaluation of human cytomegalovirus latency in alveolar macrophages. Am J Respir Crit Care Med 1994;149:495-499.

90. Smyth RL, Sinclair JSJP, Gray JJ, Higenbottam TW, Wreghitt TG, Wallwork J, Borysiewicz LK. Infection and reactivation with cytomegalovirus strains in lung transplant recipients. Transplantation 1991;52:480-481.

91. Bruggeman CA. Cytomegalovirus and latency: an overview. Virchows Arch B cell Pathol 1993;64:325-333.

92. Söderberg-Nauclear C, Fish KN, Nelson JA. Reactivation of latent human cytomegalovirus by allogeneic stimulation of blood cells from healthy donors. Cell 1997;91:119-26.

93. Chatterjee SN, Fiala M, Weiner J, Stewart JA, Stacey B, Warner N. Primary cytomegalovirus and opportunistic infections: incidence in renal transplant recipients. J Am Med Assoc 1978;240:1446-1449

94. Ahn K, Angulo A, Ghazal P, Peterson PA, Yang Y, Fruh K. Human cytomegalovirus inhibits antigen presentation by a sequential multistep process. Proc Natl Acad Sci USA 1996;93:10990-10995. 
95. Jones TR, Wiertz EJHJ, Sun L, Fish KN, Nelson, JA, Ploegh HL. Human cytomegalovirus US3 impairs transport and maturation of major histocompatibility complex class I heavy chains. Proc Natl Acad Sci USA 1996;93:11327-11333.

96. Wiertz E, Jones T, Sun L, Bogyo M, Geuze HJ, Ploegh H. The human cytomegalovirus US11 gene product dislocates MHC class I heavy chains from the endoplasmic reticulum to the cytosol. Cell 1996a;84:769-779

97. Wiertz E, Tortorella D, Bogyo M, Yu J, Mothes W, Jones T, Rapoport T, Ploegh H. Sec61-mediated transfer of a membrane protein from the endoplasmic reticulum to the proteasome for destruction. Nature $1996 \mathrm{~b}: 384 ; 432-438$.

98. Hengel H, Koopmann J, Flohr T, Muranyi W, Goulmy E, Hämmerling G, Koszinowski U and Momburg F. A viral ER-resident glycoprotein inactivates the MHC-encoded peptide transporter. Immunity 1997;6:623-632.

99. Bruggeman CA, Meijer H, Dormans PHJ, Debie WMH, Grauls GELM, van Boven CPA. Isolation of a cytomegalovirus-like agent from wild rats. Arch Virol 1982;73:231-241.

100. Meijer H, Dreesen JC, Van-Boven CP. Molecular cloning and restriction endonuclease mapping of the rat cytomegalovirus genome. J Gen Virol 1986;67:1327-1342.

101. Vink C, Beuken E, Bruggeman C. Cloning and functional characterization of the origin of lytic-phase DNA replication of rat cytomegalovirus. Joumal of General Virology 1997;78:2963-2973.

102. Beisser P, Vink C, Van Dam J, Grauls G, Vanherle S, Bruggeman C. The R33 protein-coupled receptor Gene of Rat Cytomegalovirus plays an essential role in the pathogenesis of viral infection. Journal of Virology $1998 ; 72 ; 3: 2352-2363$.

103. Beisser P, Grauls G, Bruggeman C, Vink C. Deletion of the R78 G protein-coupled receptor gene from rat cytomegalovirus results in an attenuated, syncytium-inducing mutant strain. 1999 (submitted).

104. Bruggeman CA, Debie WM, Grauls G, Majoor G, Van-Boven CP. Infection of laboratory rats with a new cytomegalo-like virus. Arch Virol 1983;76:189-199.

105. Bruggeman CA, Meijer H, Bosman F, van Boven CPA. Biology of RCMV infection. Intervirology 1985;24:19.

106. Stals FS, Bosman F, van Boven CPA, Bruggeman CA. An animal model for the therapeutic intervention studies of CMV infection in the immunocompromised host. Arch Virol 1990;114:91-107.

107. Span AHM, Grauls G, Bosman F, Van-Boven CP, Bruggeman CA. Cytomegalovirus infection induces vascular injury in the rat. Atherosclerosis 1992;93:41-52.

108. Span AHM, Mullers W, Miltenburg AM, Bruggeman CA. Cytomegalovirus induced PMN adherence in relation to an ELAM-1 antigen present on infected endothelial cell monolayers. Immunology 1991;72:355360.

109. Span AHM, Van-Boven CP, Bruggeman CA. The effect of cytomegalovirus infection on the adherence of polymorphonuclear leucocytes to endothelial cells. Eur J Clin Invest 1989;19:542-548.

110. Vossen RCRM, Persoons MCJ, Slobbe-van Drunen MEP, Bruggeman CA, van Dam-Mieras MCE. Intracellular thiol redox status affects rat cytomegalovirus infection of vascular cells. Virus Research 1997; 48:173-183.

111. Tamura K, Ohsawa T, Koji T, Watanabe, Katamine S, Sato H and Ayabe H. Allogeneic Immune Responses Augment Rat Cytomegalovirus Replication in Rats. Transpl. Proc. 1999:31:1376-1377.

112. Koskinen P, Lemstrőm K, Bruggeman C, Lautenschlager I, Hayry P. Acute cytomegalovirus infection induces a subendothelial inflammation (endothelialitis) in the allograft vascular wall. A possible linkage with enhanced allograft arteriosclerosis. Am J Pathol 1994;144:41-50.

113. Stern H, Elek SD. The incidence of infection with cytomegalovirus in a normal population. J Hyg 1965;63:7987.

114. Kendall TJ, Wilson JE, Radio SJ, Kandolf R, Gulizia JM, Winters GL, Costanzo-Nordin MR, Malcom GT, Thieszen SL, Miller LW, McManus BM. Cytomegalovirus and other herpes viruses: do they have a role in the development of accelerated coronary arterial disease in human heart allografts? J Heart Lung Transplant 1992;11:14-20.

115. Lopez C, Simmons RL, Mauer SM, Park B, Najarian IS, Good RA. Virus infections may trigger rejection in immunosuppressed renal transplant recipients. Proc Clin Dial Transplant Forum 1972;2:107-111.

116. Light JA, Burke DS. Association of cytomegalovirus (CMV) infections with increased recipient mortality following transplantation. Transpl Proc 1979;11:79-82. 
117. Dummer JS, White LT, Ho M, Griffith BP, Hardesty RL, Bahnson HT. Morbitity of cytomegalovinus infection in recipients of heart or heart-lung transplants who received cyclosporine. J Infect Dis 1985;152:1182-1191.

118. Rubin RH, Tolkoff-Rubin NE. The problem of cytomegalovirus infection in transplantation. Progress In Transplantation 1984;1:89-114.

119. Rubin RH. Cytomegalovirus diseases and allograft loss after organ transplantation. Clin. Infect Dis. 1998:26:871.

120. Richardson WP, Colvin BB, Cheeseman SH, et al. Glomerulopathy associated with cytomegalovirus viremia in renal allografts. N Engl J Med 1981;305:57

121. Boyce NW, Hayes K, Gee D, et al. Cytomegalovirus infection complicating renal transplantation and its relationship to acute transplant glomerulopathy. Transplantation 1988;45:706

122. Von Willebrand E, Pettersson E, Hayry P. CMV infection, class II antigen expression, and human kidney allograft rejection. Transplantation 1986;42:364

123. Bosch FH, Hoitsma AJ, Janssen HP, Van Loon AM, Keone RA. Cytomegalovirus infection and disease in renal transplant patient treated with cyclosporine. Transplant Int 1989;2:92

124. Reinke P, Fiestze E, Ode-Hakim S, et al. Late renal acute allograft rejection and symptomless cytomegalovirus infection. Lancet 1994;344:1737

125. Falgas M, Snydman D, Griffith J, et al. Clinical and epidemiological predictors of recurrent cytomegalovirus disease in orthotopic liver transplant recipients. Clin. Infect Dis. 1997:25:314.

126. Humar A, Uknis M, Carlone-Jambor C, Gruessner R, Dunn D and Matas A. Cytomegalovirus disease recurrence after ganciclovir treatment in kidney and kidney-pancreas transplant recipients. Transplantation. 1999:67:94-97.

127. Lautenschlager I, Soots A, Krogerus L, Kauppinen H, Saarinen O, Bruggeman C, Ahonen J. CMV increases inflammation and accelerates chronic rejection in rat kidney allografts. Transpl Proc 1997;29:802-803.

128. Lautenschlager I, Soots A, Krogerus L, Kauppinen H, Saarinen O, Bruggeman C, Ahonen J. Effect of cytomegalovirus on an experimental model of chronic renal allograft rejection under triple-drug treatment in the rat. Transplantation 1997;64:391-398.

129. Inkinen K, Soots A, Krogerus L, Bruggeman C, Ahonen J and Lautenschlager I. CMV Increases Collagen Synthesis in Chronic Rejection in Rat Renal Allograft. Transpl. Proc. 1999:31:1361.

130. Lautenschlager I, Hockerstedt K, Jalanko H, Loginov R, Salmela K, Taskinen E, Ahonen J. Persistent CMV in liver allografts ending up with chronic rejection. Hepatology 1997;25:190-194.

131. Chou S, Dennison K. Analysis of interstrain variation in cytomegalovirus glycoprotein B sequences encoding neutralization-related epitopes. J Infect Dis. 1991:163:1229.

132. Rosen H, Christopher L, Corless L, Rabkin J and Chou S. Association of cytomegalovirus genotype with graft rejection after liver transplantation. Transplantation. 1998:66:1627-1631.

133. O'Grady JG, Alexander GJ, Sutherland S, Donaldson PT, Harvey F, Portmann B, Calne R.Y., Williams R. Cytomegalovirus infection and donor/recipient HLA-antigens: interdependent co-factors pathogenesis of vanishing bile duct syndrome after liver transplantation. Lancet 1988;2:302-304.

134. Amold JC, Portmann B, O'Grady JG, Naoumov NV, Alexander GJ, Williams R. Cytemegalovirus infection persists in the liver graft in the vanishing bile duct syntrome. Hepatology 1992;16:285-292.

135. Ho M. Epidemiology of cytomegalovirus infection in man. In: Greenough WB, Merigan TC, eds. Cytomegalovirus, Biology and Infection: Current Topics in Infectious Disease. New York: Plenum Press, 1982:79-104.

136. Alford CA. Cytomegalovirus infection. Al J Med Sci 1985;22:169-189.

137. Grattan MT, Moreno-Cabral CE, Starnes VA, Oyer PE, Stinson EB, Shumway NE. Cytomegalovirus infection is associated with cardiac allograft rejection and atheroscierosis. JAMA 1989;261:3561-3566.

138. Lemstrōm K, Koskinen P, Krogerus L, Daemen M, Bruggeman C, Hayry P. Cytomegalovirus antigen expression, endothelial cell proliferation, and intimal thickening in rat cardiac allografts after cytomegalovirus infection. Circulation 1995;92:2594-2604.

139. Rook AH. Interactions of cytomegalovirus with the human immune system. Rev Inf Dis 1988;10:S460-S467

140. Betts RF, Schmidt SG. Cytolytic IgM antibody to cytomegalovirus in primary cytomegalovirus infection in humans. J Infect Dis 1981;143:821-826.

141. Condie RM, O'Reilly RJ. Prevention of cytomegalovirus infection by prophylaxis with intravenous, hyperimmune, native unmodified cytomegalovirus globulin. Am J Med 1984;26:134-141. 
142. Ustinov J, Loginov R, Bruggeman CA, van der Meide P, Hayry P, Lautenschlager I. Cytomegalovinus induces class II expression in rat heart endothelial cells. J Heart Lung Transplant 1993;12:651

143. Iwamoto GK, Monick MM, Clark BD, Auron PE, Stinski MF, Hunninghake GW. Modulation of interleukin 1-b gene expression by the immediate early genes of human cytomegalovirus. J Clin Invest 1990;85:18531857.

144. Geist LJ, Monick MM, Stinski MF, Hunninghake GW. The immediate early genes of human cytomegalovirus upregulate expression of the interleukin-2 and interleukin-2 receptor genes. Am J Respir Cell Mol Biol 1991;5:292-296.

145. Geist LJ, Monick MM, Stinski MF, Hunninghake GW. The immediate early genes of human cytomegalovinus upregulate tumor necrosis factor-a gene expression. J Clin Invest 1994;93:474-478.

146. Koskinen PK. The association of the induction of vascular cell adhesion molecule-1 with cytomegalovirus antigenemia in human heart allografts. Transplantation 1993;56:1103-1108.

147. Burns L, Pooley J, Walsh D, Vercellotti M, Weber M and Kovacs A. Intercellular adhesion molecule-1 expression in endothelial cells is activated by cytomegalovirus immediate early proteins. Transplantation 1999:67:137-144.

148. Dallman $M$. The cytokine network and regulation of the immune response to organ transplants. Transplant Rev 1992;6:1-9.

149. Williams TJ, Hellewell PG. Endothelial cell biology. Adhesion molecules involved in the microvascular inflammatory response. Am Rev Resp Dis 1992;146:S45-S50

150. Bevilacqua M, Butcher E, Furie B, Gallatin M, Gimbrone M, Harlan J, Kishimoto K, Lasky L, McEver R, Paulson J, Rosen S, Seed B, Siegelman M, Springer T, Stoolman L, Tedder T, Varki A, Wagner D, Weissman I, Zimmerman G. Selectins: a family of adhesion receptors. Cell 1991;67:233

151. Issekutz TB. The contributions of integrins to leukocyte infiltration in inflamed tissues. Current Topics In Microbiology Immunology 1993;184:177-185.

152. Smith CW, Kishimoto TK, Abbassi O, Hughes B, Rothlein R, McIntire LV, Butcher E, Anderson DC. Chemotactic factors regulate lectin adhesion molecule 1 (LECAM-1)-dependent neutrophil adhesion to cytokine-stimulated endothelial cells in vitro. J Clin Invest 1991;87:609-618.

153. Shimizu Y, Shaw S, Graber N, Gopal TV, Horgan KJ, Van Seventer GA, Newman W. Activation-independent binding of human memory T cells to adhesion molecule ELAM-1. Nature 1991;349:799-802.

154. Dustin ML, Springer TA. T-cell receptor cross-linking transiently stimulates adhesiveness through LFA-1. Nature 1989;341:619-624.

155. Mourad W, Geha RS, Chatila T. Engagement of major histocompatibility complex class II molecules induces sustained, lymphocyte function-associated molecule 1-dependent cell adhesion. J Exp Med 1990;172:15131516.

156. Azuma H, Nadeau K, Takada M, Mackenzie $\mathrm{H}$ and Tilney $\mathrm{N}$. Cellular and molecular predictions of chronic renal dysfunction after initial ischemia/reperfusion injury of a single kidney. Transplantation 1997:64:190197.

157. Solez K, Racusen L, Abdulkareem F, Kemeny E, Willebrand von E and Truong L. Adhesion molecules and rejection of renal allografts. Kidney Int. 1997:51:1476-1480.

158. Cosman D. Control of messenger RNA stability. Immunology Today 1987;8:16-17.

159. Wren $\mathrm{S}$, Wang $\mathrm{S}$, Thai $\mathrm{N}$ et al. Evidence for early $\mathrm{Th} 2 \mathrm{~T}$ cell predominance in senoreactivity. Transplantation 1993:56:905.

160. Takeuchi T, Lowery R and Konieczny B. Heart allografts in murine systems. The differential activation of the Th2-like effector cells in peripheral tolerance. Transplantation 1992:53:1281.

161. Carlquist J, Edelman L, White W, Shelby J and Anderson J. Cytokines and rejection of mouse cardiac allografts. Transplantation 1996:62:1160-1166.

162. Besouw van N, Daane C, Vaessen L, Mochtar B, Balk A and Weimar W. Donor-specific cytokine production by graft-infiltrating lymphocytes induces and maintains graft vascular disease in human cardiac allografts. Transplantation 1997:63:1313-1318.

163. Digiovine FS, Duff GW. Interleukin 1: the first interleukin. Immunology Today 1990;11:13-20.

164. Dinarello CA. Reduction of inflammation by decreasing production of interleukin-1 or by specific receptor antagonism. Int J Tissue React 1992;14:65-75. 
165. Libby P, Warner SJ, Friedman GB. Interleukin 1: a mitogen for human vascular smooth muscle cells that induces the release of growth-inhibitory prostanoids. J Clin Invest 1988;81:487-498.

166. Smith KA. Interleukin-2: Inception, impact and implications. Science 1988;240:1169-1176.

167. Smith KA. The interleukin-2 receptor. Annu Rev Cell Biology 1989;5:397-425.

168. Adams P, Lee HS, Ferguson R and Orosz C. Alloantigenicity of human endothelial cells. Transplantation 1994:57:115-122.

169. Grant S, Guy S, Lamb W, Brooks N, Brenchley P and Hutchinson I. Expression of cytokine messenger RNA after heart transplantation. Transplantation 1996:62:910-916.

170. Arai KI, Lee F, Miyajima A, Miyatake S, Arai N, Yokota T, Cytokines: coordinators of immune and inflammatory responses. Annu Rev Biochem 1990;59:783-836.

171. Johnson RB. Monocytes and macrophages. N Engl J Med 1988;318:747-752.

172. Neta R, Sayers TJ, Oppenheim JJ. Relationship of TNF to interleukins. Immunol Series 1992;56:499-566.

173. De Maeyer E, De Maeyer-Guignard J. Interferon-gamma. Curr Opin Immunol 1992;4:321-326.

174. Nagano H, Mitchell R, Taylor M, Hasegawa S, Tilney N, Libby P. Interferon- $\gamma$ deficiency prevents coronary arteriosclerosis but not myocardial rejection in transplanted mouse heart. J. Clin. Invest. 1997:100:550-557.

175. Nagano H, Libby P, Taylor M, Hasegawa S, Stinn J, Becker G, Tilney N and Mitchell R. Coronary Arteriosclerosis after T-cell-mediated injury in transplanted mouse hearts. Am.J.Path. 1998:152:1187-1197.

176. D'Elios M, Josien R, Manghetti M, Amedeo A, de Carli M, Cuturi M, Blancho G, Buzelin F, del Prete G and Soulillou JP. Predominant Th 1 cell infiltration in acute rejection episodes of human kidney grafts. Kidney Int. 1997:51:1876-1884.

177. Josien R, Pannetier C, Douillard P, Cantarovich D, Menoret S, Bugeon L, Soulillou JP, Cuturi MC. Graft infiltrating $\mathrm{T}$ helper cells, CD45RC phenotype and Th1/Th2-related cytokines in donor specific transfusion -induced tolerance in adult rats. Transplantation 1995:60:1131-1139.

178. Van Snick J. Interleukin-6: an overview. Ann Rev Immunol 1990;8:253-278.

179. Ross R, Raines EW, Bowen-Pope DF. The biology of platelet-derived growth factor. Cell 1986;46:155-169.

180. Bowen-Pope DF, Vogel A, Ross R. Production of platelet-derived growth factor-like molecules and reduced expression of platelet-derived growth factor receptors accompany transformation by a wide spectrum of agents. Proc Natl Acad Sci USA 1984;81:2396-2400.

181. Shin GT, Khanna A, Ding R, Sharma V, Lagm M, Li B and Suthanthira M. In vivo expression of transforming growth factor- $\beta$ in humans. Transplantation 1998:65:313-318.

182. Sporn MB, Roberts AB, Wakefield LM, De Crombrugghe B. Some recent advances in the chemistry and biology of transforming growth factor-beta. J Cell Biology 1987;105:1039-1045.

183. Majesky MW, Lindner V, Twardzik DR, Schwartz SM, Reidy MA. Production of transforming growth factor b 1 during repair of arterial injury. J Clin Invest 1991;88:904-910.

184. Waltenberger J, Wanders A, Fellstrom B, Miyazono K, Heldin C-H, Funa K. Induction of transforming growth factor-b during cardiac allograft rejection. J Immunol 1993;151:1147-1157.

185. Wahl SM. Transforming growth factor beta (TGF-b) in inflammation: a cause and a cure. J Clin Immunol 1992;12:61-72.

186. Lindner V, Reidy MA. Proliferation of smooth muscle cells after vascular injury is inhibited by an antibody against basic fibroblast growth factor. Proc Natl Acad Sci USA 1991;88:3739-3743.

187. Yanagisawa $M$, Kurihara $H, K$ imura S, et al. A novel potent vasoconstrictor peptide produced by vascular endothelial cells. Nature 1988:332:411.

188. Watschinger B, Vychytil A, Schuller M, et al. Pathophysiological role of endothelin in acute vascular rejection after renal transplantation. Transplantation 1991:52:743.

189. Watschinger B, Sayegh M, Hancock W, Russell M. Up-regulation of endothelin-1 m RNA and peptide expression in rat cardiac allografts with rejection and arteriosclerosis. Am. J. Pathol. 1195:146:1065.

190. Nagano H, Nadeau K, Takada M, Kusaka M and Tilney N. Sequential cellular and molecular kinetics in acutely rejecting renal allografts in rats. Transplantation 1997:63:1101-1108.

191. Ohta K, Hirata Y, Imai T, et al. Cytokine induced release of endothelin-1 from porcine renal epithelial cell line. Biochem Biophys Res Commun. 1990:169:578. 


\section{3}

CORRELATION BETWEEN THE INTENSITY OF CYTOMEGALOVIRUS INFECTION AND THE AMOUNT OF PERIVASCULITIS IN AORTIC ALLOGRAFTS 


\begin{abstract}
We previously demonstrated that cytomegalovirus (CMV) infection enhances the perivascular inflammation in rat aorta allografts. In this study, we investigated the relation between the CMV infection load and the magnitude of perivasculitis (chronic rejection) in aortic transplants. Rats received orthotopic abdominal aorta grafts, different degrees of total body irradiation for immunosuppression, and CMV inoculation. The spleen of the rats receiving $5 \mathrm{~Gy}$ of total body irradiation contained more infectious virus and viral antigens than that of the rats receiving $3 \mathrm{~Gy}$ of total body irradiation or no total body irradiation. Although the number of inflammatory cells infiltrating the perivascular area was decreased after total body irradiation, CMV infection resulted in increased perivasculitis in rats that received $5 \mathrm{~Gy}$ of total body irradiation as compared to non-infected animals. This virus-induced effect was characterized predominantly by an increased CD4 and CD8 T cells T cell infiltration. It is concluded that systemic CMV infection during severe immunosuppressive therapy can accelerate the development of chronic rejection, which seems to be mediated mainly by $\mathrm{T}$ cells.
\end{abstract}




\section{INTRODUCTION}

Transplant associated arteriosclerosis (TAA) or chronic rejection is the major cause of diminished long-term survival of transplanted organs (1). In cardiac allograft recipients the incidence of TAA is nearly $50 \%$ at 5 years after transplantation (2). The most common pathological features of TAA are persistent perivascular inflammation (perivasculitis) and intimal thickening in arteries (arteriosclerosis changes) of grafts (3).

The factors responsible for initiation and progression of TAA are not completely understood. Among others, TAA may be induced or accelerated by virus infections, such as CMV infection (4). There is strong clinical evidence that CMV infections play a role in the pathogenesis of cardiac allograft arteriosclerosis (5). CMV nucleic acids have been identified in the coronary arteries of heart allografts with severe accelerated arteriosclerosis $(6,7)$.

Previous work in our laboratory showed that immunosuppression enhanced the replication of CMV in the host leading to massive virus infection in almost all the organs (8), and that treatment with anti-CMV therapy reduced the development of intimal thickening in the vascular wall of allografts (9). However, it has not been elucidated whether the systemic CMV infection load, dependent of the degree of immunosuppression, influences the extent of transplant perivasculitis. For this purpose we used the rat aorta transplantation as a specific model to investigate the effects of enhanced virus infection on the perivascular inflammatory response.

\section{MATERIALS AND METHODS}

\section{Animals and aorta transplantation}

Male inbred specific pathogen free (SPF) Brown Norway $\left(B N / M ; R_{1 n}\right)$ and Lewis (LEW/N; $\mathrm{RT}_{11}$ ) rats, weighing $250-300 \mathrm{~g}$, were used as donors and recipients. In donor operation, a segment of abdominal aorta $(1.8-2 \mathrm{~cm})$ between the left renal artery and bifurcation was removed with all side branches ligated after intravenous administration of heparin ( $50 \mathrm{IU})$. The grafts were transplanted orthotopically into recipients with end-to-end anastomosis technique. Total ischemic time varied from 25 to 35 minutes, during which the grafts were kept cold with $4^{\circ} \mathrm{C}$ PBS.

\section{Experimental design}

The aortic grafts from BN/M rats were transplanted to LEW/N recipients (allogeneic) or to BN/M recipients (syngeneic). After transplantation, the animals were randomly divided into several groups (Table 1). A total body irradiation of 3 or $5 \mathrm{~Gy}$ was used as immunosuppression therapy. The rats of the RCMV-infected group were inoculated intraperitoneally with $10^{5}$ plaque forming units of rat cytomegalovirus (RCMV, Maastricht strain (10)). The animals received either inactivated RCMV (iRCMV), which was derived from the same virus pool and inactivated by ultraviolet irradiation, were mock infected (controls). The recipients were sacrificed either on day 7 or day 28 after transplantation. Tissue samples of the grafts and other organs were removed and divided into several pieces, which were processed either for frozen and paraffin sections, or for plaque assay. 


\begin{tabular}{|c|c|c|c|c|c|}
\hline Group & Transplantation & $\begin{array}{c}\text { Number } \\
\text { of rats }\end{array}$ & $\mathrm{TBI}^{\mathrm{I}}$ & $\begin{array}{l}\left.\mathrm{RCMV}^{2}\right) \\
\text { Infection }\end{array}$ & $\begin{array}{c}\text { Day of } \\
\text { sacrifice }\end{array}$ \\
\hline 1 & Syngeneic & 5 & No & + & 7 \\
\hline 2 & Syngeneic & 5 & No & - & 7 \\
\hline 3 & Allogeneic & 5 & No & + & 7 \\
\hline 4 & Allogeneic & 5 & No & - & 7 \\
\hline 5 & Allogeneic & 4 & $3 \mathrm{~Gy}$ & + & 7 \\
\hline 6 & Allogeneic & 4 & $3 \mathrm{~Gy}$ & - & 7 \\
\hline 7 & Allogeneic & 3 & $5 \mathrm{~Gy}$ & + & 7 \\
\hline 8 & Allogeneic & 4 & $5 \mathrm{~Gy}$ & - & 7 \\
\hline 9 & Syngeneic & 5 & No & + & 28 \\
\hline 10 & Syngeneic & 5 & No & - & 28 \\
\hline 11 & Allogeneic & 5 & No & + & 28 \\
\hline 12 & Allogeneic & 5 & No & - & 28 \\
\hline 13 & Allogeneic & 3 & $3 \mathrm{~Gy}$ & + & 28 \\
\hline 14 & Allogeneic & 3 & $3 \mathrm{~Gy}$ & - & 28 \\
\hline 15 & Allogeneic & 6 & $5 \mathrm{~Gy}$ & + & 28 \\
\hline 16 & Allogeneic & 5 & $5 \mathrm{~Gy}$ & - & 28 \\
\hline 17 & Allogeneic & 4 & 5 Gy & IRCMV & 28 \\
\hline
\end{tabular}

Table I. Summary of experimental groups

1) Total body irradiation (TBI) was performed on day 1 after transplantation.

2) RCMV inoculation was performed intraperitoneally at 6 hours after total body irradiation.

\section{Virus detection}

Immunocytochemical techniques (8) were used for detection of RCMV antigens in grafts using RCMV monoclonal antibodies (mAbs) 8 and 35 described previously (11). For the detection of infectious virus infection, the organs (salivary glands, spleen and liver) were collected aseptically. These organs were homogenized in a tissue grinder and suspended in cell culture medium containing $2 \%$ foetal calf serum. Quantitation of infectious virus was done by plaque assay $(10,12)$. For this purpase, 10 -fold dilutions of $10 \%$ homogenates $(\mathrm{wt} / \mathrm{vol})$ were inoculated on a confluent rat embryonal fibroblast monolayer. After an incubation period of 7 days, the number of plaques was monitored microscopically after fixation and methylene blue staining. 


\section{Histological and immunohistochemical staining of grafts}

A segment of the graft fixed in $3.7 \%$ buffered formalin was embedded in paraffin, and examined histologically after sectioning and staining with haematoxylin-eosin. The aortas from nontransplanted rats were used as normal controls.

Four-micron thick cross sections of grafts were stained with three-layer (paraffin sections) or two layer (frozen sections) indirect immunoperoxidase technique using monoclonal antibodies: W3/13 (Sera-lab Ltd, Crawley Down, UK), a mouse monoclonal antibody to rat pan T cells; ED1 (kindly supplied by Dr. Dijkstra, Dept. of Immunology, Free University, Amsterdam, The Netherlands), a mouse monoclonal antibody to rat monocytes/macrophages ; Ox-8 (Sera-lab Ltd, Crawley Down, UK), a mouse $\mathrm{IgG}_{1}$ monoclonal antibody to rat CD8 $\mathrm{T}$ cells; and $\mathrm{W} 3 / 25$ (Seralab Ltd, Crawley Down, UK), a mouse $\mathrm{IgG}_{1}$ monoclonal antibody to rat $\mathrm{CD} 4 \mathrm{~T}$ cells.

\section{Quantitation of extent of perivasculitis}

The total number of nuclei (TNN) and positive stained cells for W3/13 (T cells), ED-1 (monocytes/macrophages) and $\mathrm{Ox}-8$ (CD8 T cells) in aortic adventitia was quantitated in the cross sectioned grafts, and expressed as point score units (PSU), i.e. the mean number of points falling over given anatomical areas using straight, cross-sectional lines, and a $100 \mathrm{~mm}^{2}$ square eye piece micrometer under a magnification of 400 times. Under this magnification, a total area of $400 \mathrm{~mm}^{2}$ was counted. While the positive stained cells for W $3 / 25$ were scored from 0 to $5(0$, no staining; 1 , very weak; 2 , weak; 3 , moderate; 4 , intense; 5 , very intense specific staining). Data are expressed as mean \pm SEM. The number of positive cells or TNN in different groups were statistically compared with the aid of the nonparametric Mann-Whitney U test. P values < 0.05 were regarded as statistical different.

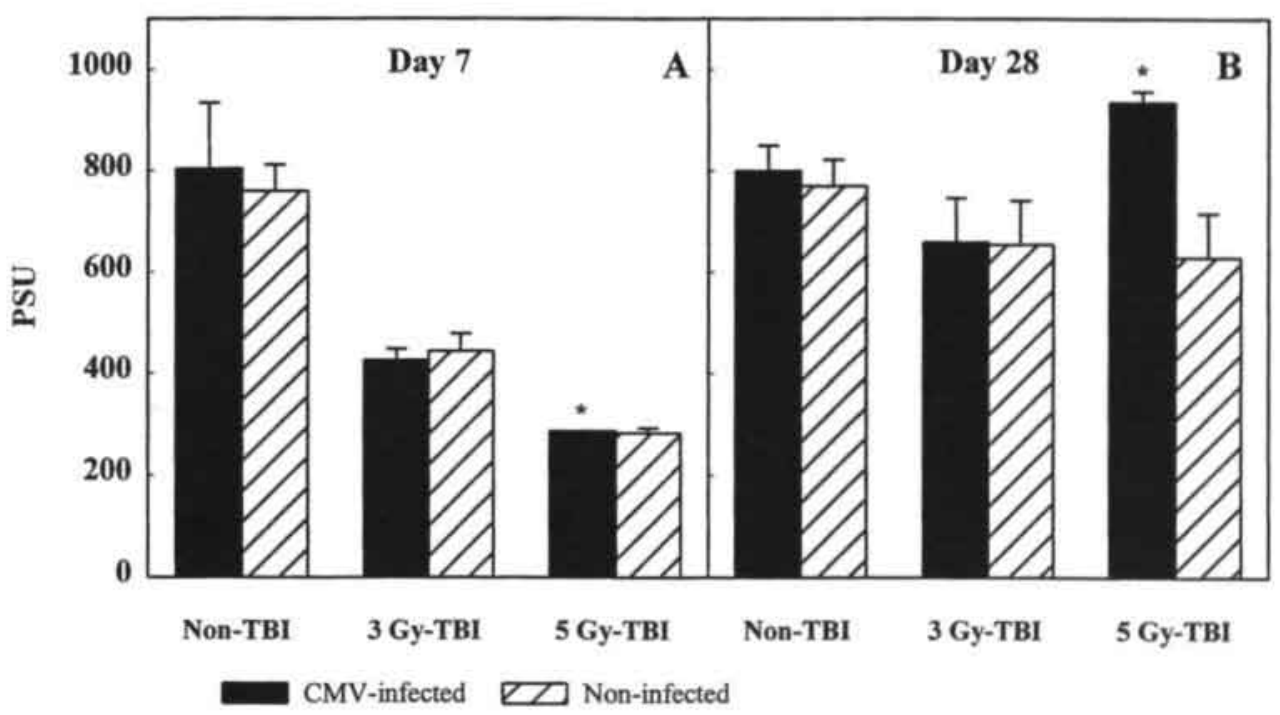

Fig. 1. Total mumber of muclei in the adventitia of aortic allografts at 7 and 28 days after transplantation. Data are expressed as mean \pm SEMIPSU. $* P<0.05$ when compared with the non-infected group. 


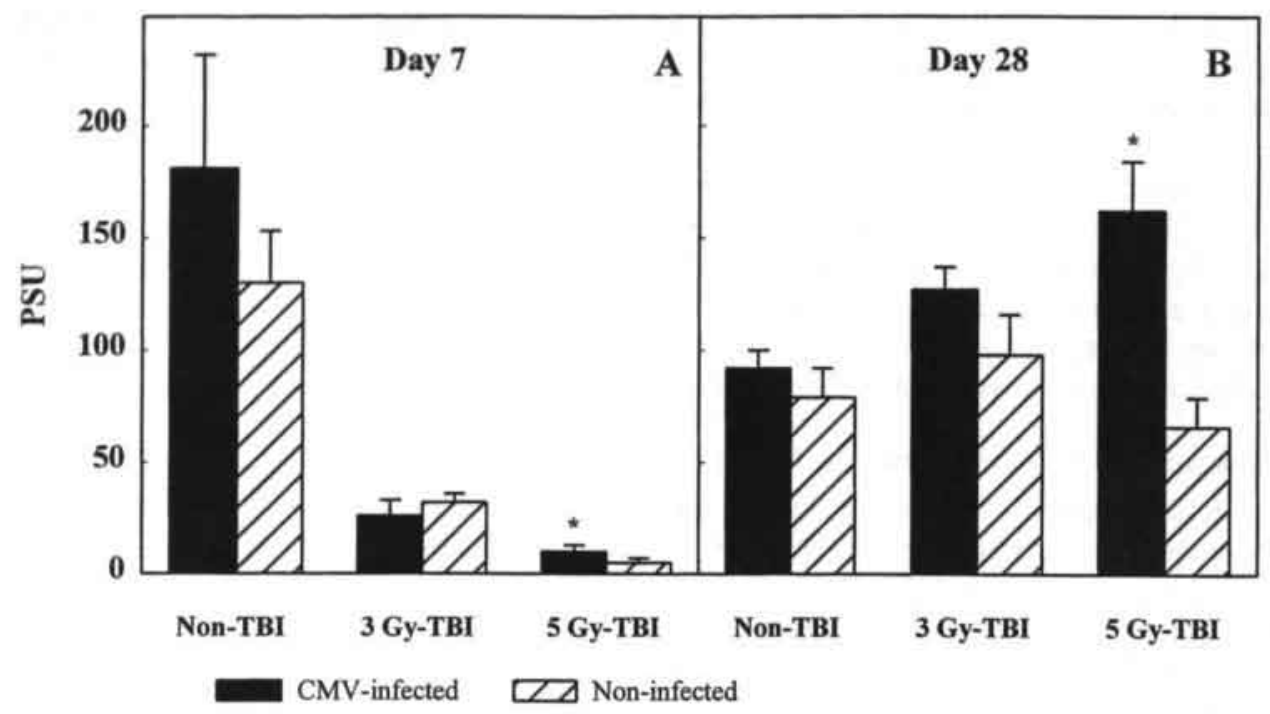

Fig. 2. The mumber of total $T$ cells in adventitia of aortic allografts at 7 and 28 days after transplantation. Data are expressed as mean \pm SEMVPSU. $* P<0.05$ when compared with the non-infected group.

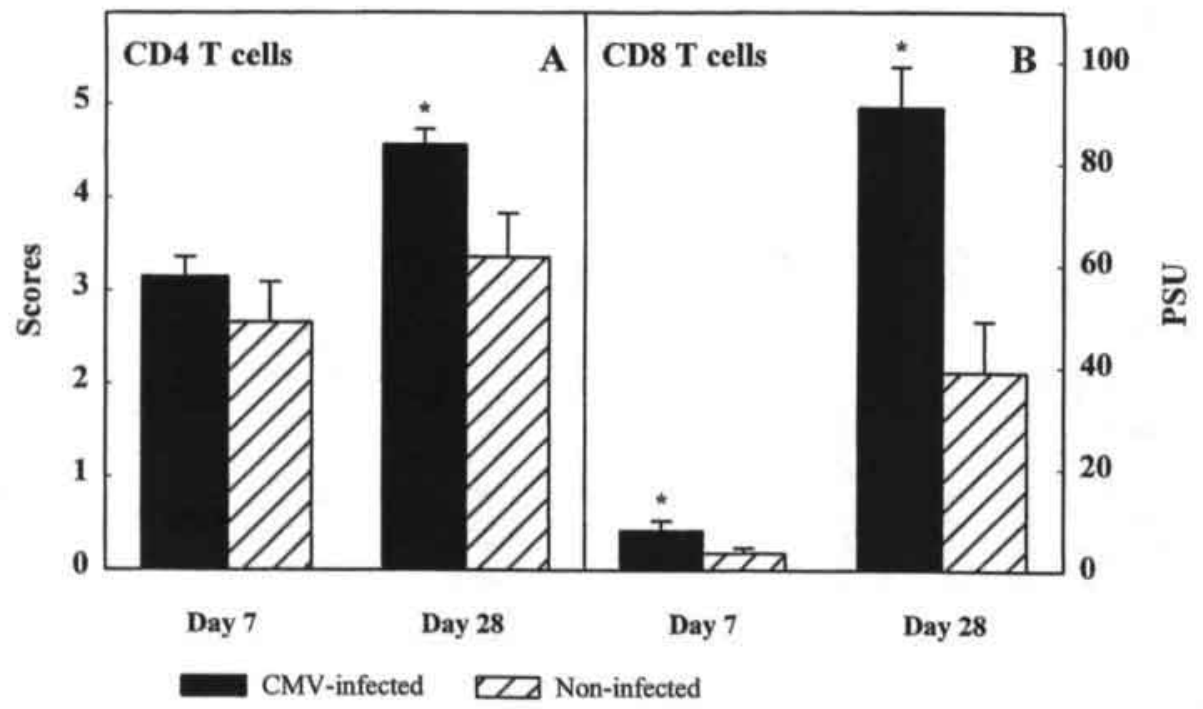

Fig. 3. The mumber of CD4 and CD8 T cells in the adventitia of aortic allografis in animals that received 5 Gy total body irradiation at 7 and 28 days after transplantation. Data are expressed as mean \pm SEMUPSU or Scores. * $P$ $<0.05$ when compared with the non-infected group. 


\section{RESULTS}

\section{RCMV infection}

Two out of four RCMV-inoculated rats that received 3 Gy of total body irradiation and five out of six rats that received 5 Gy of total body irradiation harboured infectious RCMV in their spleens at 7 days after transplantation. Virus culture from the salivary glands and liver was negative at the same time point. At day 28 , only salivary glands harboured infectious RCMV, while no infectious virus was found in the liver and spleen of both syngeneic and allogeneic recipients that received 3 or $5 \mathrm{~Gy}$ total body irradiation. In iRCMV inoculated control rats, no virus was cultured from any organs.

Sporadic RCMV-antigen harbouring cells in the adventitia were detected in the allografts at 7 and 28 days after transplantation. More RCMV-reactive cells were present in recipients with total body irradiation than without total body irradiation although this difference was not significant. No viral antigens were detectable in syngeneic and allogeneic grafts and allografts of iRCMVinoculated rats irrespective of total body irradiation.

\section{Magnitude of perivasculitis}

Without the application of total body irradiation the TNN in the allografts of the RCMV-infected group did not differ from that in the non-infected group at 7 days after transplantation (Figure 1A). The TNN was decreased in rats that received $3 \mathrm{~Gy}$ total body irradiation as compared to that of non-total body irradiation rats $(\mathrm{P}<0.05)$. Nevertheless, after $3 \mathrm{~Gy}$ total body irradiation no significant difference in TNN was observed between the RCMV-infected and non-infected rats. In animals that received $5 \mathrm{~Gy}$ total body irradiation, the TNN was further decreased as compared to animals that received $3 \mathrm{~Gy}$ total body irradiation $(\mathrm{P}<0.05$ ). However, after $5 \mathrm{~Gy}$ total body irradiation, a significant difference in the TNN was observed between the RCMV-infected and non-infected groups $(\mathrm{P}<0.05)$. At 28 days after transplantation in the animals that received either non total body irradiation or $3 \mathrm{~Gy}$ total body irradiation, no significant difference in TNN could be found between the RCMV-infected and non-infected rats (Figure 1B). However, in the rats that received 5 Gy total body irradiation the TNN in the RCMV-infected group was significantly higher than in the non-infected group $(\mathrm{P}<0.05)$. Moreover, after RCMV infection, the TNN was higher in the animals that received 5 Gy total body irradiation than in those received $3 \mathrm{~Gy}$ total body irradiation $(\mathrm{P}<0.05)$. Meanwhile, the TNN in the rats that received iRCMV did not differ from that in the non-infected rats, but was significant less than in the RCMV-infected rats that received 5 Gy total body irradiation $(\mathrm{P}<0.05)$.

The number of infiltrating $T$ cells in the allografts is shown in Figure 2. At 7 days after transplantation (Figure $2 \mathrm{~A}$ ), the number of infiltrating $\mathrm{T}$ cells decreased significantly with an increase of the degree of total body irradiation from non total body irradiation to $3 \mathrm{~Gy}$ total body irradiation and 5 Gy total body irradiation, respectively $(\mathrm{P}<0.05)$. Nevertheless, no significant difference in the number of T cells could be found between the RCMV-infected group and the non-infected group that received either no or $3 \mathrm{~Gy}$ total body irradiation. In contrast, after $5 \mathrm{~Gy}$ total body irradiation, there was a significant increase in the number of T cells in the RCMVinfected group as compared to the non-infected group $(\mathrm{P}<0.05)$. At 28 days after transplantation (Figure 2B), there was no significant difference in T cell infiltration between the RCMV-infected 
In conclusion, our results indicate that enhanced general RCMV infection has a detrimental effect on development of TAA of aortic allografts in highly immunocompromised recipients. This CMV-associated process, which appears to be $\mathrm{T}$ cell mediated, is accelerated by an increased immunosuppressive regimen.

\section{REFERENCES}

1. Paul LC, Fellström B (1992) Chronic vascular rejection of the treatment options emerged? Transplantation 53: $1169-1179$

2. Gao S.Z., Alderman E.L., Schroeder J.S., Siverman J.F.,Hunt S.A. (1988) Accelerated coronary vascular disease in the heart transplant patient: coronary arteriographic findings. J. Am. Coll. Cardiol. 12:334-340

3. Hăyry P (1994) Chronic allograft rejection: An update. Clin Transplantation 8:160-161

4. Kendall TJ, Wilson JE, Radio SJ, Kandolf R, Gulizia JM, Winters GL, Costanzo-Nordin MR, Malcom GT, Thieszen SL, Miller LW, McManus BM (1992) Cytomegalovirus and other herpes viruses: do they have a role in the development of accelerated coronary arterial disease in human heart allografts? J Heart Lung Transplant 11: $14-20$

5. McDonald K, Thomas S. Rector, Elizabeth A. Braunlin, Spencer H. Kubo, and Maria Teresa Olivari (1989) Association of coronary artery disease in cardiac transplant recipients with cytomegalovirus infection. Am J Cardiac 64: 359-362

6. Hruban RT, Wu TC, Beschorner WE, Cameron DE, Ambinder RF, Baumgartner WA, Hutchins GM, and Reitz BA (1990) Cytomegalovirus nucleic acids in allografted hearts. Hum Pathol 21: 981-983

7. Wu TC, Hruban RH, Ambinder RF, Pizzorno M, Cameron DE, Baumgartner WA, Reitz BA, Haywaed GS, and Hutchins GM (1992) Demonstration of cytomegalovirus nucleic acids in the coronary arteries of transplanted heart. Am J Pathol 140: 739-747

8. Stals FS, Bosman F, van Boven CPA, and Bruggeman CA (1990) An animal model for therapeutic intervention studies of CMV infection in the immunocompromised host. Arch Virol 114:91-107

9. Bruning JH, Persoons M, Lemström K, Stals FS, De Clercq E, Bruggeman CA (1994) Enhancement of transplantation-associated atherosclerosis by $\mathrm{CMV}$, which can be prevented by antiviral therapy in the form of HPMPC. Transpl Int 7[Suppl]: S365-s370

10. Bruggeman CA, Meijer H, Dormans PHJ, Debie WMH, Grauls GELM, and van Boven CPA (1982) Isolation of a cytomegalovirus-like agent from wild rats. Arch Virol 73: 231-241

11. Bruning JH, Debie WHM, Dormans PHJ, Meijer H, Bruggeman CA (1987) The development and characterisation of monoclonal antibodies against rat cytomegalovirus induced antigens. Arch Virol 94:55-70

12. Bruggeman CA, Meijer H, Bosman F, van Boven CPA (1985) Biology of rat cytomegalovirus infection. Intervirology $24: 1-9$

13. Bruggeman CA, Li FL, Stals FS (1995) Pathogenicity: Animal models. Scand J Infect (in press)

14. Yang H, Dundon PL, Nahill SR, Welsh RM (1989) Virus-induced polyclonal cytotoxic T lymphocytes stimulation. J Immunol 142:1710-1718

15. Via CS, Shanley JD, Shearer GM (1990) Synergistic effect of murine cytomegalovinus on the induction of acute graft-vs-host disease involving MHC Class I differences only. Analysis of in vitro T cell function. J Immunol 145:3283-3289

16. Cray C and Levy RB (1989) The ability of murine cytomegalovirus and class I major histocompatibility complex-disparate parental cells to induce alterations characteristic of severe graft-versus-host reactions. Transplantation 48:1057-1063

17. Geist LJ and Hunninghake GW (1994) Cytomegalovirus as a trans-activator of cellular genes. Semin Virol 5:415-420

18. Waldman WJ, Adams PW, Orosz CG, Sedmak DD (1992) T lymphocyte activation by cytomegalovirusinfected, allogeneic cultured human endothelial cells. Transplantation 54: 887-896

19. Waldman WJ, Knight DA (1995) Cytokines-mediated induction of endothelial MHC and adhesion molecule expression by cytomegalovirus-activated T cells. Abstract presented on the Int. Symposium on the etiology and pathobiology of transplant vascular sclerosis, March 1-5, Bermuda. 


\section{4}

INITIAL ENDOTHELIAL INJURY AND

CYTOMEGALOVIRUS INFECTION ACCELERATE THE DEVELOPMENT OF ALLOGRAFT ARTERIOSCLEROSIS 


\begin{abstract}
Accelerated transplant arteriosclerosis or chronic rejection, which is characterized by persistent perivascular inflammation and myointimal hyperplasia, is the major limitation to long term survival after cardiac transplantation (1). Many factors are involved in development of the accelerated transplant arteriosclerosis. Endothelial injury has been purported to be able to precipitate intimal lesion development in human atherosclerosis (2). In addition, a positive correlation between the presence of the cytomegalovirus (CMV) genome in the arterial wall and the grade of atherosclerotic changes was found in non-immunosuppressed patients $(3,4)$. The purpose of this study was to investigate the role of endothelial injury and CMV infection in development of accelerated transplant arteriosclerosis, i.e. whether intimal thickening and enhanced perivascular inflammation are related to endothelial injury and CMV infection in rat aortic transplant model.
\end{abstract}




\section{MATERIALS AND METHODS}

\section{Animals and operation}

Specific pathogen free (SPF) male inbred Brown Norway (BN/M; RT $T_{1 n}$ ) and Lewis (LEW/N; $\mathrm{RT}_{11}$ ) rats, weighing $250-300 \mathrm{~g}$, were used as donors and recipients. Aortic transplantation was performed from BN to LEW (allogeneic) or from BN to BN (syngeneic). A section of the abdominal aorta between the left renal artery and the bifurcation was removed from donor rat. The graft was transplanted orthotopically below renal arteries and above bifurcation into the recipient rat. Total ischemic time varied from 25 to $35 \mathrm{~min}$. At different time point after transplantation, the recipient rats were sacrificed and the grafts were removed for analysis.

Longitudinal and cross section study: In order to quantitate the extent of endothelial injury, intimal thickening and perivascular inflammation, the aortic grafts were fixed in formaline and sectioned longitudinally or crossly for histology and immunohistochemistry.

To study the causative role of CMV infection in enhanced perivascular inflammation, we gave rat cytomegalovirus (RCMV) infection and 5 Gy total body irradiation to the recipient rats in both syngeneic and allogeneic groups on day 1 after transplantation. The animals were sacrificed at day 28 , aortic grafts were fixed in formaline or frozen in isopentane for cross sections. The biopsies from salivary glands, liver and spleen were taken at the time of sacrificing for plaque assay.

\section{Immunohistochemical staining}

Four-micron thick longitudinal and cross sections of aortic grafts were stained with three-layer (paraffin sections) and two layer (frozen sections) indirect immunoperoxidase technique using the monoclonal antibodies W3/13 (T cells); ED-1 (monocytes/macrophages); Ox-8 (T-cytotoxic); W3/25 (T-helper); Ox-39 (interleukin-2 receptor); Ox-1 (Leukocyte common antigen); Ox-6 (MHC class II antigen); RECA-1 (rat endothelium); vWF (von Willebrand factor); a-actin (smooth muscle cell).

\section{Quantitation of histology in rat aortic transplants}

Longitudinal section: The endothelial injury, neointima formation and inflammation in adventitia of grafts were scored from 0 to 3 . For endothelial injury, no denudation was scored as 0 , focal denudation as 1 , multifocal denudation as 2 , massive denudation as 3. For neointima formation, percentage of the maximum thickness of neointima in the sum of neointima and media was scored as: $0 \%=0,0-25 \%=1,25-50 \%=2$, over $50 \%=3$. For perivascular inflammation, the density of positive stained inflammatory cells was evaluated, 0 represents no positive staining, 1 scattering positive staining, 2 moderate staining, 3 strong staining. All the scores were taken both at anastomosis and at midgraft segment.

Cross section: The number of total nuclei and positive staining for W3/13, ED-1, Ox-8, Ox-39 was quantitated in term of positive cells in adventitia layer of cross sectioned graft and expressed as point score units (PSU) as described previously (5). Positive staining for W3/25, Ox-1, Ox-6 was scored from 0 to 5 ( 0 , no positive staining; 1 , very weak; 2 , weak; 3 , moderate; 4 , intense; 5 , very intense positive staining). Data are expressed as mean $\pm \mathrm{SEM}$. 


\section{Chapter 4}

\section{RESULTS}

\section{Longitudinal section study}

Histological changes in aortic grafts: the extent of neointima formation at anastomosis area known as the area with enhanced endothelial cell damage was compared with the middle segment of aortic grafts. At day 7, the neointima formation could be observed in anastomosis of allografts, but not in the middle part. At day 28 , the neointima was observed in the middle segment, but it was much thicker at the anastomosis (Fig.1). Three months after transplantation, the thickness of the neointima became diffused and uniform over the whole length of the allograft (Fig. 1). The neointima consisted of smooth muscle cells and some inflammatory cells at day 7 , almost only smooth muscle cell at day 28 and thereafter. In syngeneic grafts, a faint and very limited neointima formation was observed only at anastomosis after day 7 (Fig. 1).

Immunohistological findings: endothelial cell denudation was observed as early as day 2 in both allo- and isografts (Fig. 1). This endothelial cell injury was more severe in the anastomosis than that in the midgraft segment. When compared to the syngeneic grafts, the endothelial cell injury was more severe in the allografts. Regeneration of endothelial cell was observed at day 7, the regeneration was not completed until day 28 . vWF deposition was seen only in the anastomosis area of allografts at day 7 , thereafter it became decreased and disappeared. Perivascular inflammation ( $\mathrm{T}$ cells and monocytes/macrophages) in allografts was observed at day 2 after transplantation, reached the peak at day 28 and persisted till 6 months. At day 2 , inflammation in the anastomosis was slightly more than in the middle part.

\section{Cross section study:}

Virus detection: sporadic inflammatory cells were found as RCMV antigen positive in the adventitia of aortic allografts by the immunoperoxidase technique. In the syngeneic grafts, no RCMV antigen positive cells were found in adventitia. In contrast, salivary glands, liver and spleen contained large amount of virus in both syngeneic and allogeneic RCMV-infected recipients, as demonstrated by plaque assay.

Cellular counts: in hematoxylin-eosin staining, the total number of nuclei in the adventitia of aortic grafts was counted and expressed as point score units (PSU). A few cells (mainly fibroblasts) were observed in adventitia of syngeneic grafts. In allografts, the total number of nuclei in the RCMV infected group was significant higher than in the non-infected group ( 937.3 \pm 27 vs $632.8 \pm 91, \mathrm{P}<0.05)$.

The inflammatory cells in the adventitia: in syngeneic grafts, no or few positive stained cells in adventitia were observed. In allografts, the number of W3/13, Ox-8, W3/25, Ox-1, Ox-6 positive cells were significant higher in RCMV infected group as compared to non-infected group (Fig. 2). 


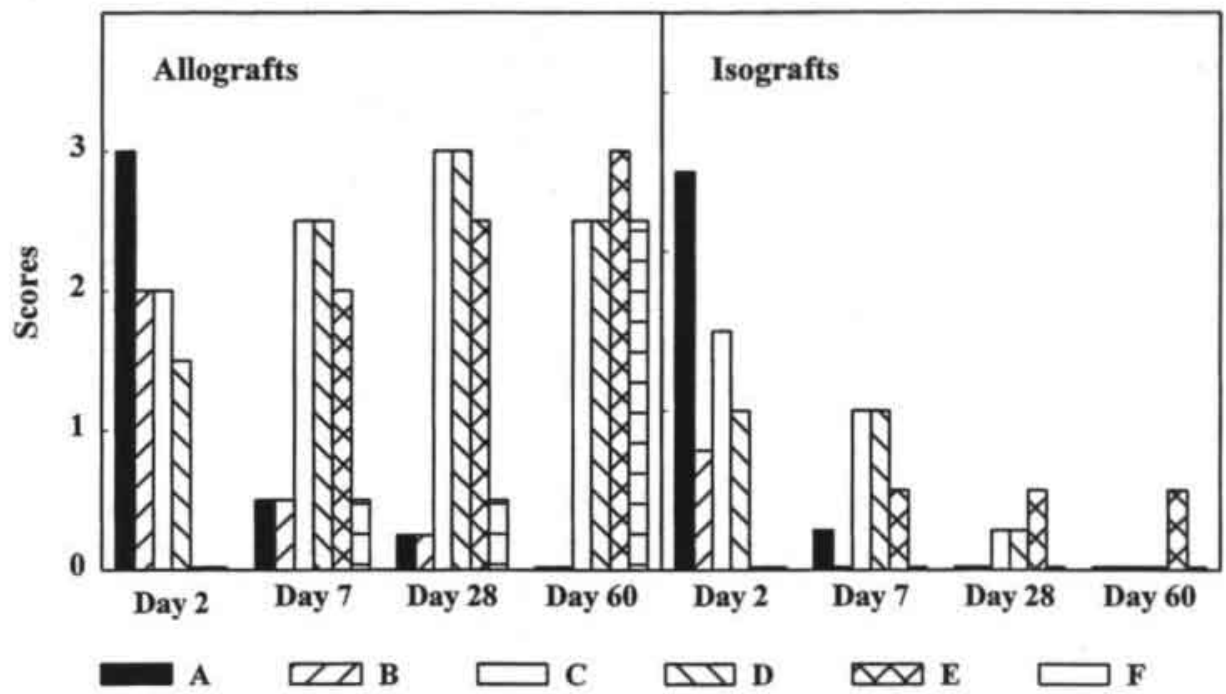

Fig.1. The endothelial injwry, neointima thickening and perivascular inflammation in aortic grafts at different days after transplantation. A symbolizes endothelial demudation at anastomosis; B represents endothelial demudation in midsegment; $C$ perivascular inflammation in anastomosis; $D$ perivascular inflammation at midsegment; $E$ intimal thickening at anastomosis; $F$ intimal thickening at midsegment.

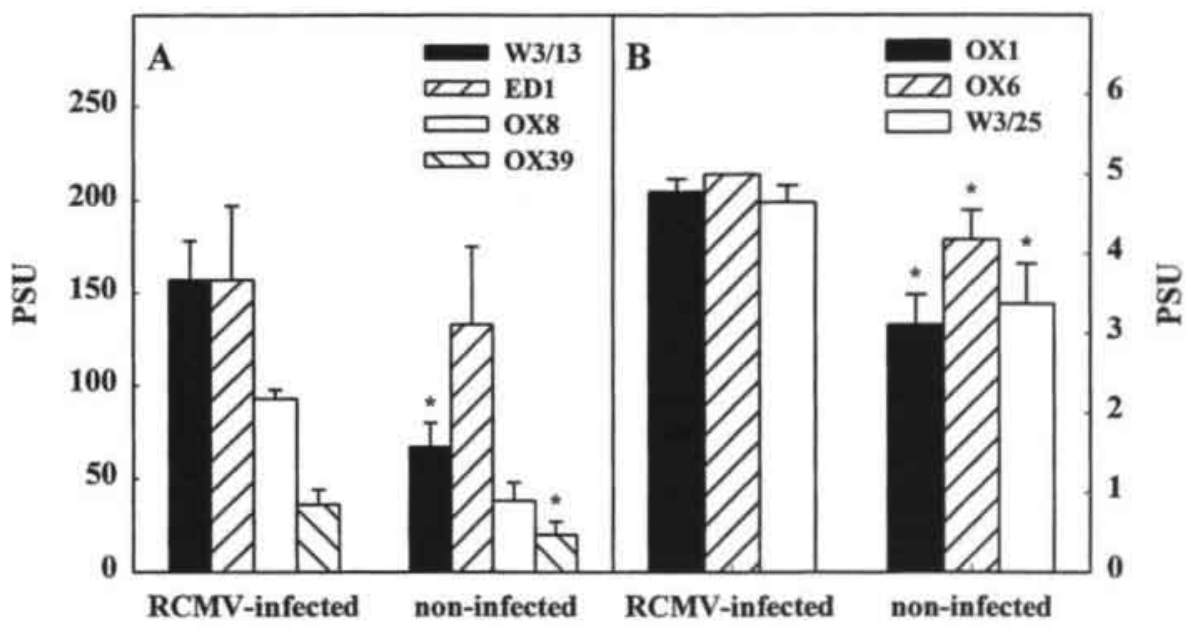

Fig.2. Inflammatory cell subsets in adventitia of aortic allografts. Data are expressed as mean \pm SEM. PSU represents point score units. ${ }^{*} P<0.05$ when the $R C M V$-infected rats are compared with the non-infected rats. 


\section{Chapter 4}

\section{DISCUSSION AND CONCLUSION}

The cause of accelerated transplant arteriosclerosis is almost certainly multifactorial (6). This study demonstrates a possible causative role of initial endothelial injury and CMV infection in development of accelerated transplant arteriosclerosis. Our results show that endothelial cell injury is more severe at the anastomosis area than at the midsegment of allografts soon after transplantation, likewise, the following neointima formation was generated earlier and faster at anastomosis area than at midgraft segment. In syngeneic grafts, although endothelial injury is present (less severe as compared to the allografts), neointima formation at anastomosis was very faint and limited. A widely held concept in atherosclerosis research is that loss of endothelium precipitates intimal lesion development (2). Our findings indicate that endothelial cell injury might be one of the risk factors in development of transplant arteriosclerosis especially when the allogeneic reaction exists, although its contribution is rather small and seems to be limited to a early period after transplantation.

Perivascular inflammation is one of the main features of accelerated transplant arteriosclerosis. In our study, RCMV infection was found in adventitia where the perivascular inflammation was enhanced. Previous study in our laboratory demonstrated that RCMV did nearly not infect the aortic endothelium in the rats (7), which is confirmed by present study. In this study, an enhanced perivascular inflammation after CMV infection is observed in the allografts but not in the syngeneic grafts (data not shown). Previous work showed that RCMV infection enhances intimal thickening in the aortic allografts $(5,8)$. This suggests a correlation between perivascular inflammation and the formation of intimal thickening in the aortic grafts. The exact mechanism of this virus induced inflammation and neointimal thickening is subject for further study.

In conclusion, endothelial cell injury may lead to early neointima formation especially when an allogeneic reaction occurs. CMV infection enhances perivascular inflammation which may expedite intimal thickening of allogeneic transplants, therefore, accelerates the development of allograft arteriosclerosis.

\section{References}

1. Ewel CH, Foegh ML (1993) Chronic graft rejection: accelerated transplant arteriosclerosis. Immunol Rev. $134: 21-31$

2. Reidy MA, Schwartz SM (1984) Recent advances in molecular pathology. Arterial endothelium assesment of in vivo injury. Exp Mol Pathol 41: 419-434

3. Hendrix MGR, Dormans PHJ, Kitslaar P, Bosman F, Bruggeman CA (19989) The presence of cytomegalovirus nucleic acid in arterial walls of atherosclerotic and nonatherosclerotic patients. Am J Pathol 134: 1151

4. Hendrix MGR, Salimans MMM, van Boven CPA, Bruggeman CA (1990) High prevalence of latently present cytomegalovirus in arterial walls of patients suffering from grade III atherosclerosis. Am J Pathol 136: 23

5. Lemström KB, Bruning JH, Bruggeman CA, Lautenschlager IT, Hayry PJ (1992) Cytomegalovirus infection enhances smooth muscle cell proliferation and intimal thickening of rat aortic allografts. J Clin Invest. 92: 549-558

6. Johnson MR (1992) Transplant coronary disease: nonimmunologic risk factors. J Heart Lung Transplant 11: S124-132

7. Span AHM, Grauls G, Bosman F, van Boven CP, Bruggeman CA (1992) Cytomegalovirus infection induces vascular injury in the rat. Atherosclerosis $93 ; 41-52$ 
8. Bruning JH, Persoons M, Lemstrom K, Stals FS, De Qlercq E, Bruggeman CA (1994) Enhancement of transplantation-associated atherosclerosis by $\mathrm{CMV}$, wich can be prevented by antiviral therapy in the form of HPMPC. Transpl Int 7 (suppl 1): S365-S370 



\section{CYTOMEGALOVIRUS INFECTION ENHANCES THE PERIVASCULAR INFLAMMATORY REACTION IN TRANSPLANTED AORTIC ALLOGRAFTS}




\begin{abstract}
Background: Infections with cytomegalovirus (CMV) frequently occur in solid organ transplant recipients. Previous studies have demonstrated an association between CMV infection and chronic rejection, known to be a major cause of graft failure on the long term.

Chronic rejection is characterized by a persistent perivascular inflammatory reaction and intimal proliferation. We hypothesized that the inflammatory influx of cells, especially of the monocytes/macrophages, is important for the pathophysiology of the intimal proliferation.

Material and methods: For the study of virus induced effects on chronic rejection rat aortic allografts were analyzed at different time intervals. The animals were infected with rat cytomegalovirus (RCMV) at the day of transplantation. The appearance of inflammation in the grafts and the development of a neointima in the allografts was investigated using histology and immunohistochemical stainings.

Results: The data obtained in this study demonstrate that in the allograft a persistent inflammatory reaction was found, especially in the perivascular area, leading to the formation of a neointima. In the RCMV infected rats significant more T lymphocytes were present in the perivascular area, compared to the noninfected rats.

$\mathrm{CMV}$ infection also leads to more interleukin-2 receptor ( $\mathrm{IL}-2$ receptor) positive cells and to more MHC-class-II antigen expression in the perivascular area. The virus-induced effect was not found when ultraviolet-inactivated virus was used.

Conclusion: Aortic allograft transplantation is associated with a perivascular inflammation and a neo-intima formation. Infectious CMV leads to an enhanced influx of T lymphocytes and activation of inflammatory cells in the perivascular area. These changes provide the substrate for virus-induced enhancement of chronic rejection.
\end{abstract}




\section{INTRODUCTION}

CMV infection is a major complication in transplant recipients. Symptomatic CMV infection occurs in more than $50 \%$ of lung and heart-lung transplant recipients. In these patients pneumonitis appears in nearly $30 \%$ of the recipients $(1,2) \mathrm{CMV}$ infection leads to increased rejection which is in general managed with heightening of the immunosuppression, which in turn leads to increased susceptibility to CMV infection. CMV infection is not only related to acute rejection but it has been suggested that $\mathrm{CMV}$ is a cofactor in the genesis of chronic rejection (3, 4). Although the relation between CMV infection and chronic rejection remains controversial convincing data of this relation come from studies in cardiac transplant recipients (5-8).

In addition several studies in animals support these findings. Among them, the data of Lemström (9) clearly show that CMV infection enhances the development of chronic vascular rejection. The development of chronic rejection is an important risk factor of transplant recipients on the long run. Since improvements in immunosuppressive drug therapy and after transplantation management of acute rejection, high 1-year survival rates have been reached (10).

Chronic rejection or transplant associated arteriosclerosis or accelerated atherosclerosis has been observed in the majority of the heart allografts occuring three to more years after transplantation. It is characterized by a concentric intimal narrowing of all vessels in the graft due to the formation of a neointima. Whereas acute rejection results in endothelial cell damage, chronic rejection is characterized by an ongoing inflammation in the graft $(11,12)$.

For the study of the factors involved in the development of chronic rejection experimental animal models have been used. Most data are obtained in rat transplant models, among them the rat aortic allograft model developed by Mennander (13) has frequently been used. It is an excellent and rather simple model to study the development of chronic rejection. In this model Lemström et al (9) showed that RCMV infection of the recipient leads to an enhanced perivascular inflammatory response and an increased neointima formation. Later on similar observations were done in other transplanted organs such as hearts, lungs, livers and kidneys (14-17).

In this paper we document the development of chronic rejection in the allograft aortic transplant model (13) using the Brown Norway (BN) - Lewis (Lew) rat strain combination. We analysed the perivascular inflammation occurring in the allografted aortas and studied the development of a neointima in the grafts. Since it is not understood how CMV infection stimulates the perivascular inflammation, rats were injected with either virulent (infectious) virus or with inactivated (noninfectious) virus.

From the present and previous data, obtained in our lab (18-20) we conclude that RCMV infection of the recipient leads to enhanced influx of especially $\mathrm{T}$ lymphocytes in perivascular area of the allograft and that for this effect infectious, i.e. replicating virus, is necessary. The enhanced influx of T lymphocytes does not automatically leads to an enhancement of the neointima formation. 


\section{Chapter 5}

\section{MATERIALS AND METHODS}

\section{Experimental animals}

Inbred specific pathogen free (SPF) Brown Norway (BN) and Lewis (Lew) rat strains were used as donors and recipients respectively for all allograft transplantation experiments. For syngeneic transplantations Lew rats were used as donors and recipients. The animals were bred at the Central Animal Facility of the University of Maastricht (The Netherlands) and were housed under standardized conditions fed with commercially available pellet diet and had free access to acidified ( $\mathrm{pH} 3$ water).

\section{Aortic transplantation}

Aortic grafting was performed as described previously (21). Briefly, animals were anaesthetized with phenobarbital ( $5 \mathrm{mg} / 100 \mathrm{~g}$ body weight). An approximately $2 \mathrm{~cm}$ long segment of the abdominal aorta between left renal artery and the bifurcation was removed.

The aorta was thoroughly perfused with phosphate buffered saline ( $\mathrm{pH} 7.2$ ). The graft was transplanted orthotopically below the renal arteries and above the bifurcation into the recipient rat. The end-to-end anastomosis was performed using 8-0 continuous nylon suture. Total ischemic time varied from 30 to $40 \mathrm{~min}$, during which time the graft was kept in an icebath of $4^{\circ} \mathrm{C}$. The grafts ware removed at day 7,28 and 90 and were processed for histology or for frozen section immunohistochemistry. Each group of animals consisted of at least 5 animals.

\section{Virus infection}

RCMV, Maastricht strain (22) was used. The virus pool consisted of a pool of homogenated salivary glands of acutely infected rats (23). Recipients were infected by inoculating the animals intraperitoneally with $10^{5}$ plaque forming units (PFU) of RCMV.

To enhance the replication of the virus within its host, the animals were immunosuppressed by $5 \mathrm{~Gy}$ total body irradiation or otherwise indicated (24). As controls mock infected animals were included in the study. In order to evaluate if infectious virus is necessary for the induction of morphological changes in the allografts, noninfectious virus was used. This virus was obtained by inactivating a pool of infectious virus containing $10^{5} \mathrm{PFU} / \mathrm{ml}$ by ultraviolet irradiation followed by control of infectivity by plaque assay.

\section{Detection of CMV infection}

For detection of active CMV infection in the rats injected with RCMV, two methods are used consisting of the plaque assay and the immunohistochemical staining method using monoclonal antibodies against RCMV as described previously (24).

\section{Histological staining of speciments}

A segment of the transplanted aorta was fixed in $10 \%$ buffered formalin and embedded in paraffin. Four micron sections were made and were stained with Mayer's hematoxylin-eosin. Cross sections were made for morphological analysis. For morphometry the sections were prepared from the center of the graft to avoid the effects of suture line. Aortas of nontransplanted rats were used as controls. 


\section{Immunohistochemistry}

Frozen four micron thick sections were made of the aortas and were stained with the immunoperoxidase technique. The sections were incubated with primary mouse monoclonal antibodies (mAbs), after washing, a rabbit anti-mouse peroxidase labelled secondary antibody (Amersham) was added. The sections were then treated with the peroxidase substrate solutions as described previously (18).

Mouse mAbs W $3 / 25$ to $\mathrm{CD}^{+}$cells and $\mathrm{OX}-8$ to $\mathrm{CD} 8^{+}$cells were purchased from Seralab (Crawley Down U.K.). Monocytes and macrophages were stained using mAbs ED1 and ED2 obtained from dr. C. Dijkstra, Amsterdam, The Netherlands. mAb LFA-1, a mouse mAb to rat lymphocyte function-associated antigen-1 (LFA-1) and ICAM-1 a mouse IgG mAb to rat intercellular adhesion molecule-1 (ICAM-1), were supplied by Dr. Masayuki Miyasaka, Department of Bioregulation, Biochemical research center, Osaka University Medical School, Japan. To control for specificity of signals, the same procedures were performed with irrelevant monoclonal antibodies. For detection of the $\mathrm{IL}-2$ receptor mouse $\mathrm{mAb}$ OX-39 was used, while for MHC class II antigen detection mAb OX-6, from Seralab, was used.

\section{Quantification of histology in rat aortic transplant}

The morphological changes are quantified using a semiquantitative scoring technique as described previously (21). The scores, from 0 to 5 , were given as follows:

$0=$ no staining; 1 = very weak; 2 = weak; $3=$ moderate; $4=$ intense and $5=$ very intense specific staining. Data are expressed as mean \pm SEM.

\section{Morphometric analysis}

The cross-sectional areas and thickness of intima and media of the aortic allografts were measured by using a computer-assisted morphometric system (Quantimet, 570; Leica). The cross-sectional area of the media was defined as the area between the external and internal elastic lamina. The neointimal cross-sectional area was defined as the area between the arterial lumen. The results of the measurements are expressed in $\mu^{2}$ for the areas and in time for the thickness and were given as means \pm SEM.

\section{Statistical methods}

All data are expressed as mean \pm SEM, if not otherwise indicated. The non-parametric MannWhitney U-test was used to evaluate the significances of histological changes between infected and noninfected aortic allografts at certain timepoints. $\mathrm{P}$ values $<0,05$ were regarded as statistically significant.

\section{RESULTS}

\section{CMV infection in the transplant recipient}

All infected recipients, receiving RCMV intraperitoneally, remained healthy. No signs of CMV disease were observed in all infected animals at all times. 
Chapter 5

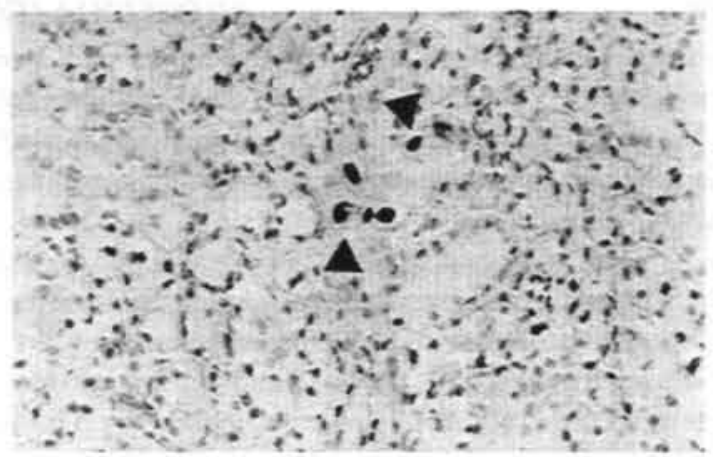

Fig 1. Presence of RCMV antigens in the salivary gland of rats injected with $10^{5} P F U$ infectious RCMV. Cells containing RCMV early and late antigens ( $\pi)$, as stained with RCMV mAbs 8 and 35 were found.
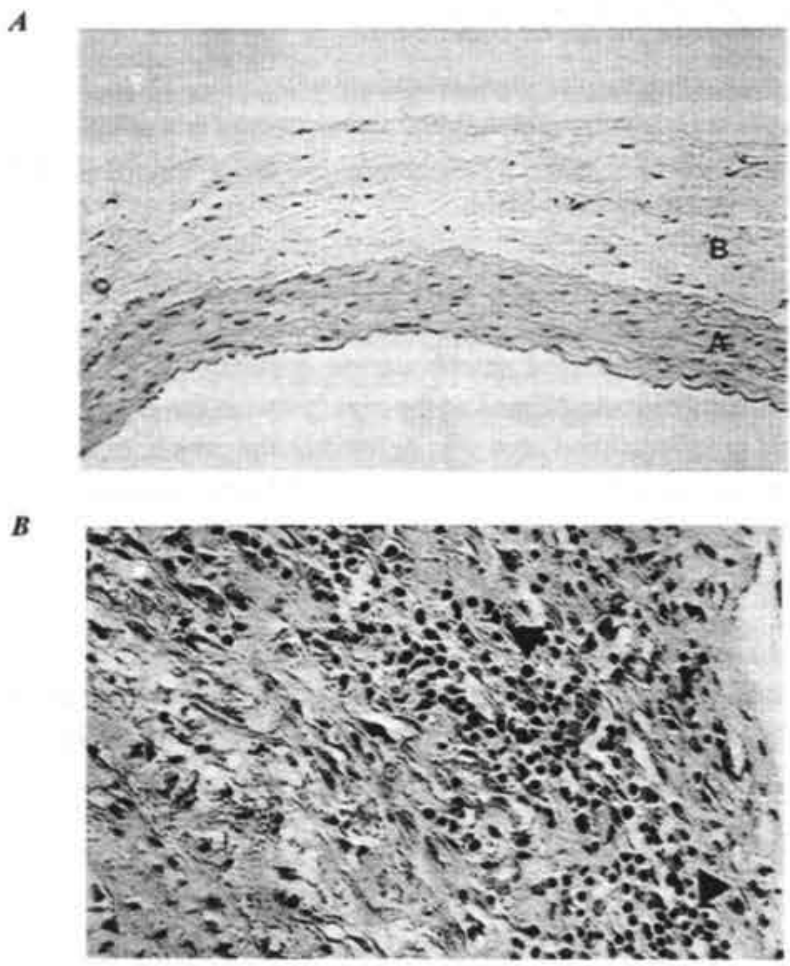

Fig. 2. A. Microphotograph of the vascular wall of a syngeneic transplanted aorta media (A) perivascular area (B). Haematoxylin-eosin staining $(20 x)$.

B Microphotograph of the influx of leukocytes $(\pi)$ in the perivascular area of a transplanted aorta of a RCMV infected rat. Haematoxylin-eosin staining $(40 x)$. 
Biopsies of the salivary glands, the preferent organ for CMV replication, were positive in all infected rats at day 28 and 90 after infection as shown by plaque assay and immunohistochemistry (Fig. 1).

In the aortas nearly no active infection could be detected by both techniques. During the first week after infection very low levels of RCMV-infected cells, especially monocytes/macrophages were found in the perivascular area (mean $1.1 \pm 0.3$ ), later on, at days 28 and 90 , no infected cells were detectable in the allografted aortas.

In syngeneic grafts low levels of RCMV infection were detectable (mean $1 \pm 0.1$ ) at day 7 . At days 28 and 90 no signals of RCMV positivity were found in the aortas.

In uninfected controls no infectious virus or viral antigens were detectable in all rats.

\section{Allograft transplantation leads to enhanced perivascular inflammation}

In each group at least five technically successful allografts were examined for the appearance of morphological changes in the allografts at days 7,28 and 90. Corresponding syngeneic controls were examined at the same timepoints.

In the allografts, an influx of cells was found in the perivascular area, while in the intima and the media no or very low levels of inflammatory cells, as detected by the hematoxylin-eosin staining, were found (Fig. 2). In the perivascular area mainly monocytes and lymphocytes were found starting at day 7 and reaching significant higher levels at day 28 (Fig. 3). Thereafter the number of cells in the perivascular area declined reaching lower levels at day 90 than at day 28 . In the RCMV infected animals a slight, although not significant, increase was observed at each timepoint when compared to the noninfected rats. In the syngeneic controls no perivascular influx of cells was found.

\section{$C M V$ infection leads to an enhanced influx of $T$ lymphocytes in the perivascular area of the aortic allografts}

Using the immunoperoxidase staining technique the inflammatory cells were characterized. In the perivascular area of the allografts an influx of monocytes/macrophages, stained with ED1 and $\mathrm{ED} 2 \mathrm{mAbs}$ and $\mathrm{T}$ lymphocytes, stained with anti-CD4 and anti-CD8 mAbs were found. The influx of ED1 positive cells started at day 7, reaching significant higher levels at day 28 (Fig. 4A). These cells persist in the perivascular area, as shown by the presence of these cells at day 90. In the syngeneic grafts very low levels (mean score $<1$ ) were found in the perivascular area at all timepoints. A similar pattern was found for ED2 positive cells (data not shown). In the RCMV infected rats a slight, but not significant increase of the number of ED1 and ED2 positive cells was observed in the allografts at all time points.

In the syngeneic grafts no ED1 or ED2 positive cells were found in both the infected and the noninfected rats at all measurepoints. In the perivascular area of the aortic allografts an infiltration of $\mathrm{CD}^{+}$and $\mathrm{CD} 8^{+} \mathrm{T}$ lymphocytes was observed. These cells were detectable at day 7 after transplantation and their number increased, reaching significant higher levels at day 28 , declining afterwards. As was also found for the ED1 and ED2 positive cells, T lymphocytes persist at least till day 90 after transplantation as shown in Fig.5. In the syngeneic grafts no or very low levels (mean score less than 0.33 ) of $T$ lymphocytes were found (data not shown). RCMV infection of the recipients did result in an increased influx of CD4 and CD8 T cells, 


\section{Chapter 5}

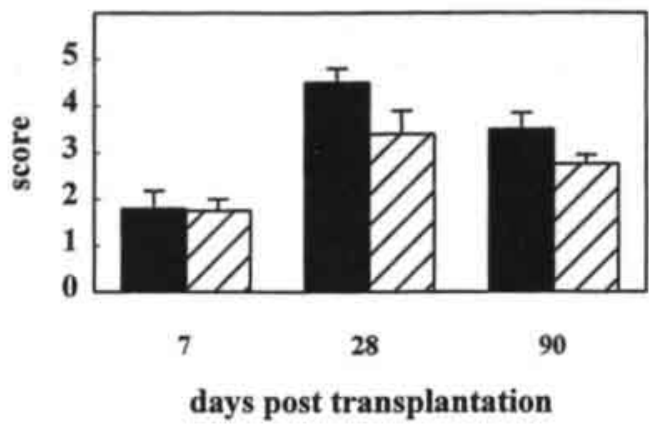

Fig. 3. Influx of inflammatory cells in the perivascular area of aortic allografts. The cells were stained with hematoxilin-easin and were scored semi-quantitatively from 0 to 5. The scores are expressed as mean \pm SEM. Significant more inflammatory cells were found in both infected and uninfected rats at day 28 than at day $7(P<0.05)$.

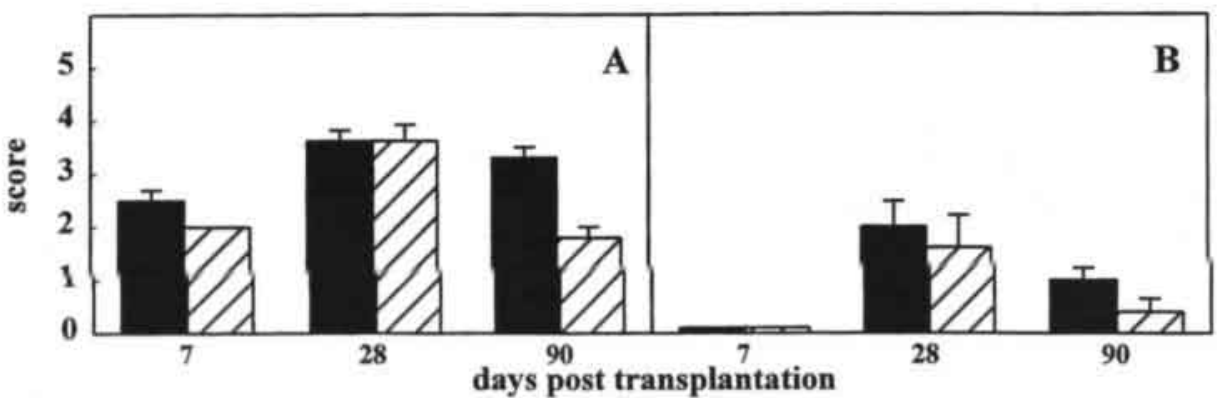

Fig. 4. Presence of EDI positive cells in the perivascular area (A) and the intima (B) of aortic allografts. The cells were stained by EDI mAbs and were scored semi quantitatively. The scores are expressed as means \pm SEM. A high number of EDI positive cells was found in the perivascular area and in the intima of the allografts of infected and non infected recipients at day 28. The mumber of cells was significantly higher at day 28 compared to day 7 and to day $90(P<0.05)$

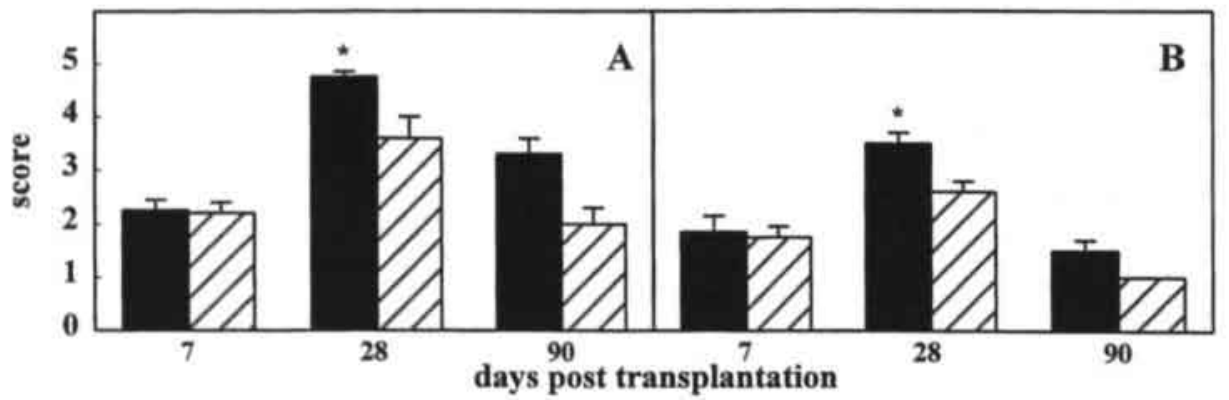

Fig. 5. Presence of $\mathrm{CDA}^{+}$(A) and $\mathrm{CD} 8^{+}$(B) T lymphocytes in the perivascular area of the aortic allografts. The cells were scored semi-quantitatively. The scores were expressed as mean \pm SEM. Significant higher mumbers of $C D 4^{+}$and $C D 8^{+}$cells $(P<0.05)$ was found at day 28 compared to day 7 in both the infected and the non infected rats. In the $R C M V$ infected rats significant more $(*)(P<0.05) C D 4^{+}$and $C D 8^{+} T$ lymphocytes were found in the infected group than in the uninfected group. 
especially at day 28 a significant higher concentration of these cells was found in the RCMV infected rats compared with noninfected rats.

\section{Allograft transplantation leads to an influx of inflammatory cells in the intima}

In the aortic allografts the influx of cells in the intima was much lower than in the perivascular area. The same effect was found in the media of the allografts, where the concentration of inflammatory cells in this compartment was even lower than in the intima (data not shown). In the intima ED1 positive monocytes/macrophages were found starting at day 28 after transplantation (Fig. 4B), while at day 7 no EDl positive cells were observed. The presence of ED1 positive cells was not found in the syngeneic controls. No significant difference in the concentration of ED1 positive cells was found between infected and noninfected rats (Fig. 4B). In the intima no ED2 positive cells and no $\mathrm{CD}^{+}$or $\mathrm{CD} 8^{+} \mathrm{T}$ lymphocytes were observed at all timepoints of both infected and noninfected rats.

\section{RCMV infection leads to activation of cells in the aortic allografs}

To measure the effect of RCMV infection on the expression of MHC class II antigens the immunoperoxidase technique with $\mathrm{mAb}$ OX 6 was used. As shown in Fig. 6A increased expression of MHC class II antigens was found in the intima at day 28 after transplantation. The expression of MHC class II antigens persisted for several months giving scores of $1.33 \pm 0.33$ (mean $\pm \mathrm{SEM}$ ) and $1.2 \pm 0.2$ (mean $\pm \mathrm{SEM}$ ) at day 90 in the infected and the noninfected rats respectively. No significant difference has been found between infected and noninfected rats at each timepoint.

In the perivascular area MHC class II positive cells were detectable in allografts starting at day 7 after transplantation and persisting till at least day 90 (Fig. 6B). At day 90 in the RCMV infected allograft significant more MHC class II positive cells are observed $(\mathrm{P}<0.05)$. In the syngeneic grafts very low levels (mean score less than 0.33 ) of MHC class II positive cells were found.

To detect the presence of activated T lymphocytes expression of $I L-2$ receptor was measured at different intervals after transplantation. As shown in Fig. 7 the expression of $\mathrm{IL}-2$ receptor was present in allografts at day 7 and reached higher levels at day 28 , persisting in the perivascular area till at least 90 days after transplantation. Significant more IL-2 receptor positive cells were found in the RCMV infected allografts at day 28 than in the uninfected allografts $(\mathrm{P}<0.05)$. In syngeneic grafts no expression of $I L-2$ receptor was found in all rats. No IL-2 receptor positivity was observed in the intima.

\section{Expression of adhesion molecules and their ligands is upregulated in the aortic allografts}

To detect the expression of adhesion molecules and their ligands the appropriate mAbs were used. The expression of ICAM-1 was detected on the endothelial cells of all allografts. At day 7 after transplantation low levels were scored (mean score \pm SEM of $1.1 \pm 0.4$ in the infected rats and of $1.75 \pm 0.25$ in the uninfected rats). The expression of ICAM-1 increased thereafter, reaching high scores at day 28 ; in the infected rats the mean score \pm SEM was $4.25 \pm 0.25$, while in the uninfected rats the mean score \pm SEM was $3.75 \pm 0.48$. Later on the expression of ICAM-1 declined giving scores of $1.17 \pm 0.31$ in the infected rats and $0.4 \pm 0.25$ in the uninfected rats at 


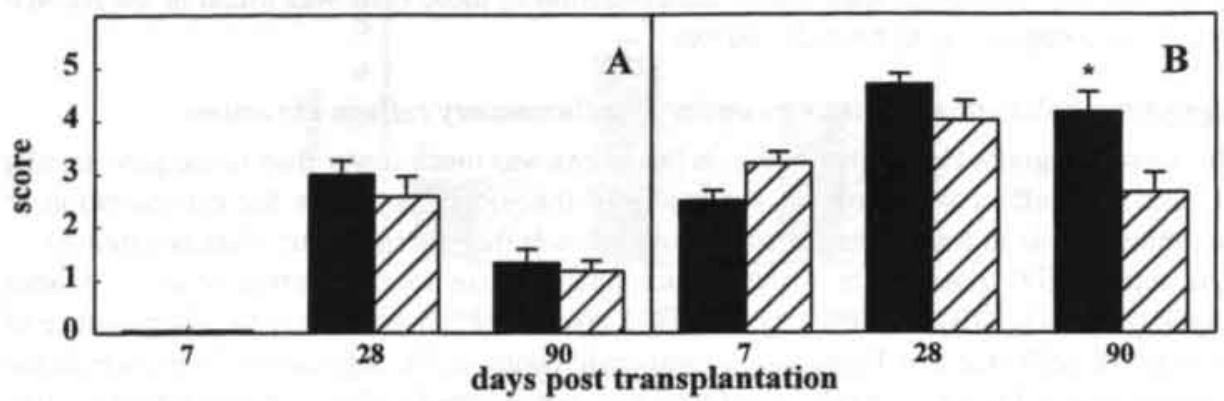

Fig. 6. Expression of MHC class II antigens on cells in the perivascular area (B) and in the intima (A) of aortic allografts at different times after transplantation. The expression of MHC class Il antigens was scored semi-quantitatively using mAbs OX 6 and was expressed as mean \pm SEM. In the RCMV infected group significant $\left(\left(^{*}\right)\right.$ more $(P$ $<0.05)$ MHC class II positive cells were found in the perivascular area compared to the uninfected controls.

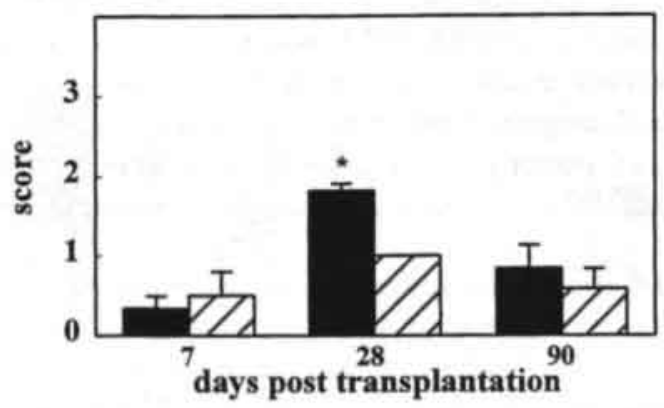

Fig. 7. Presence of $I L-2$ receptor positive cells in the perivascular area of aortic allografts. The prevence of $I L-2$ receptor was scored semi quantitatively using $m A b$ OX 039. The scores are expressed as mean $\pm S E M$. In the RCMV infected grafts significant $(*)$ more $(P<0.05) 1 \mathrm{~L}-2$ receptor positive cells were detected than in the uninfected controls.

day 90. In the syngeneic controls no or very low levels expression of ICAM-1 was found at all measure points.

The expression of LFA-1 in the perivascular area was measured for all animals. LFA-1 expression was present in the perivascular area of all aortic allografts. An increased expression of LFA-1 was detectable at day 28 compared to day 7 and day 90 respectively (at day 28 in the uninfected rats the mean score \pm SEM was $3.4 \pm 0.25$ while at day 7 the scores were $1 \pm 0$; in the infected group the mean score \pm SEM at day 28 was $3.4 \pm 0.25$, while at day 7 the mean score was $1 \pm 0$ ). RCMV infection of the recipients did not lead to a significant upregulation of the expression of LFA-1. In the media and the intima nearly no LFA-1 expression was detectable in all animals.

\section{Aortic allograft transplantation leads to formation of a neointima}

Transplantation of aortic allografts leads to neointima formation in the allografts. This process was visible at day 28 after transplantation, while at day 7 no neointima could be found in all 
allografts. In the noninfected animals the thickness of the intimal layer expressed as mean \pm SEM at day 28 was $5.6 \pm 2$, while at day 90 an intimal thickness of $79.6 \pm 10.7$ was found (Table 1). In the syngeneic grafts no neointima formation was found. The intimal area expressed in $\mu \mathrm{m}^{2}$ (mean \pm SEM) in the allografts was respectively $13952 \pm 4621$ at day 28 and $225834 \pm 31422$ at day 90 (Table 1). In the RCMV infected animals a tendency to increase was found, but the differences in neointima formation expressed as intimal thickness or as intimal area between RCMV infected and uninfected rats at the same timepoint were not significant. The thickness of the media did not show significant differences between aortic allografts at different timepoints (data not shown). No effect of RCMV infection was found on the thickness of the media.

\section{Generalized infection with infectious virus is necessary for the upregulation of the perivascular inflammation}

As can be seen in Fig. 5 injection of infectious RCMV into highly immunosuppresed rats, obtained by $5 \mathrm{~Gy}$ total body irradiation, leads to an upregulation of the influx of $\mathrm{T}$ lymphocytes as shown by the enhanced concentration of $\mathrm{CD} 4^{+}$and $\mathrm{CD} 8^{+} \mathrm{T}$ lymphocytes in the perivascular area. This upregulation was significant higher at day 28 after transplantation in the infected compared to uninfected allografts at the same timepoint. This phenomenon is a constant observation in the allografts of all RCMV infected rats and has been found previously in several rat strains that have been used in our laboratory (18-20).

To investigate if infectious virus is necessary to obtain such an effect, rats were inoculated with ultraviolet-inactivated RCMV. The effect of this injection on the influx of T lymphocytes was measured as described previously. In these animals no increased influx of T lymphocytes on day 28 and 90 was found in the perivascular area of the allografts suggesting that injection of inactivated virus does not lead to an upregulation of the perivascular inflammatory response.

\begin{tabular}{|c|c|c|c|}
\hline \multicolumn{2}{|c|}{ Animal group (n=5/group) } & \multicolumn{2}{c|}{ Neointima formation } \\
\hline Day of sacrifice & RCMV infection & Intimal area" & Intimal thickness ${ }^{2)}$ \\
\hline & & & \\
\hline 7 & + & 0 & 0 \\
\hline 7 & - & 0 & $7.5 \pm 1.9$ \\
\hline 28 & + & $20957 \pm 5776$ & $5.6 \pm 2$ \\
\hline 28 & - & $13952 \pm 4621$ & $94 \pm 103$ \\
\hline 90 & + & $236064 \pm 25705$ & $79.6 \pm 10.7$ \\
\hline 90 & - & $225834 \pm 31422$ & \\
\hline
\end{tabular}

Table 1. Neointima formation in the aortic allografts

1) Intimal area is expressed in $\mu m^{2}$. The mean value \pm SEM is given.

2) Intimal thickness is expressed in $\mu \mathrm{m}$. The mean value \pm SEM is given. 


\section{Chapter 5}

\section{DISCUSSION}

The pathogenesis of chronic rejection and the effect of CMV infection in the process remain poorly understood. The results described in this paper are in agreement with previous data from our and other groups $(9,18,25-28)$, showing that CMV infection leads to an enhanced inflammatory response in the allografts, especially in the perivascular area. The infiltrating cells consist mainly of monocytes/macrophages and T lymphocytes. In the presented data, using the BN - Lew rat strain combination, it was found that RCMV infection of the recipient rat leads to a significant increase of infiltrating $\mathrm{T}$ lymphocytes $\left(\mathrm{CD}^{+}\right.$and $\left.\mathrm{CD}^{+}\right)$in the perivascular area of the allografts. A similar phenomenon was observed by others $(9,25,27)$. A striking difference between our data and the data obtained by Lemström et al $(9,27)$ is that in our experiments, RCMV infection did not lead to an enhanced neointima formation at three months after transplantation while in the experiments of the Finnish group significant enhanced neointima formation was observed in the CMV infected animals. Although no definitive explanation can be given yet for this difference, one possible explanation is that differences in the rat strain combinations used are of importance in the genesis of a neointima. In the experiments of Lemström other rat strains were used than in our experiments, i.e., in their experiments DA rats were used as donors and WF rats as recipients. Recent work in our lab (19) supports this hypothesis, as it showed that indeed the rat strain combination used is very important for the appearance of a virus-induced effect on the development of the neointima in the allografts. In these experiments (19) using either Lew or Wag/rij rats as donors and RP rats as recipients, differences in the virus induced effect on the neointima formation were observed depending on the rat strain combination used. In the Lew RP rat strain combination RCMV infection leads to an increased neointima formation, while in the Wag/rij - RP rat strain combination no virus effect on the neointima formation could be observed. These data are in agreement with experiments with mouse cytomegalovirus (MCMV) in mice (29), showing that genetic factors are very important for virus induced effect on graft rejection.

The underlying mechanism by which CMV infection is associated with enhanced neointima formation has not been elucidated. A major role may be attributed to virus-linked perivascular inflammation, resulting in activation of cells, leading into the release of immune-active mediators such as cytokines and growth factors. These growth factors are necessary for the proliferation of smooth muscle cells, resulting in the formation of a neointima.

In our experiments an increased influx of T lymphocytes is observed in the RCMV infected rats but this influx does not automatically correlate with a virus induced increase of neointima formation as shown in table 1 .

Previous data, using different rat strain combinations (19) are more in favour of a correlation between influx of monocytes/macrophages and enhancement of neointima formation. This observation leads to the hypothesis that in the aortic transplant model, the influx of monocytes/macrophages is the most important factor for the formation of a neointima.

From the monocyte/macrophage it is known that it is a very important cell, since this cell is producer of several factors, such as cytokines and growth factors, factors known to play a key role in the formation of a neointima.

Cytokines are important mediators of cell-to-cell communication. These compounds play an important role in a variety of pathophysiological processes. IL-6 is an important regulator of 
inflammation and immunity such as activation of T lymphocytes (30) The major source of this cytokine are cells from the monocyte/macrophage lineage. Local production of IL-6 by monocytes/macrophages may be an important mechanism by which local and systemic inflammatory processes are regulated.

It is known that during viral infection the production of IL-6 is very high, so that by this way, viral infection is involved in enhanced local inflammation (31).

In organ transplant recipients an enhanced expression of IL-6 gene is found during CMV infection (32). In addition IL-6 production within the rejected allograft coincides with the presence of cytotoxic T lymphocytes (33).

Growth factors can be produced by several cells such as endothelial cells, smooth muscle cells as well as by cells that have invaded the vessel wall, such as monocytes/macrophages. Especially monocytes/macrophages are thought to be very important cells for the production of several growth factors. The effect of growth factors on smooth muscle cell proliferation is well known. Among them platelet-derived growth factor (PDGF), epidermal growth factor (EGF) and transforming growth factor $-\beta 1$ (TGF- $\beta 1$ ) are found to be involved in chronic rejection (3). But also cytokines such as IL-1 and tumor necrosis factor (TNF) are important, since they may regulate the expression of PDGF mRNA. That growht factors play a role in chronic rejection in the aortic allografts has been suggested by Lemström (34) showing that in the RCMV infected recipients enhanced expression of PDGF - BB and TGF - B 1 is detected.

An other important factor in the development of chronic rejection is the upregulation of adhesion ligand molecules on transplanted endothelia and other cells. Adhesion molecules expressed on the surface of various cell types are important in cell-to-cell interactions (35). Adhesion molecules can be present on difference cell types such as endothelial cells and by the binding with their ligand/receptor may influence the outcome of an immune response. They are important for cellular activations and for allospecific immune responses. Allospecific inhibition of adhesion molecules by monoclanal antibodies, has been demonstrated in renal allograft rejection (36) and in heterotopic heart transplantation (37).

Viral infection enhances ICAM-1 upregulation $(15,38-40)$ and by this way stimulates the geneses of chronic rejection. In our experiments an increased expression of ICAM-1 in the allografts was observed. These data are in agreement with work of others $(14,28,34-41)$ showing a virus induced upregulation of ICAM-1.

In our model no CMV-infected endothelial cells could be demonstrated using the immunohistochemical stain technique. Nevertheless infection of these cells may be present at very low levels (below detection level) as shown by experiments in mice (42) In previous work, using in vitro infection experiments, we could detect that low levels of infection of endothelial cells lead to local release of TNF resulting in increased expression of adhesion molecules and in the induction of MHC class I and class-II on endothelial cells (38, 43-46).

The production and binding of IL-2 to IL-2 receptor are believed to be central in T cell activation and the development of the immune response such as occurs during allograft rejection. Antibodies to the receptor for IL-2 can markedly enhance survival of allografts presumably by preventing expansion of activated $T$ lympocytes (47). The presence of $I L-2$ receptor on invading cells is a marker for the "activation" state of these cells. In our experiments expression of IL-2 receptor positive cells is found in the perivascular area of the allografts. In the RCMV infected 
recipients an increased expression was found. This increase is maximal at day 28 after transplantation. At the same time point an increased influx of both $\mathrm{CD} 4^{+}$and $\mathrm{CD} 8 \mathrm{~T}$ lymphocytes is found, suggesting that these invading $\mathrm{T}$ lymphocytes, are at least partly, activated.

In addition the enhanced expression of MHC class II antigens in the both perivascular area and on the endothelial cells is an important observation in the light of the development of chronic rejection $(3,48,49)$. RCMV infection leads to an increased expression of MHC class II antigens in the perivascular area, a phenomenon also observed in other RCMV infected organs (50).

Similar observations were done by Lemström (34) and $\mathrm{Li} \mathrm{(19)}$ in aortic allografts and also in other organ transplants such as in lungs and kidneys, indicating that on RCMV enhanced expression of MHC class II is a common observation during RCMV infection of the host (51, $52)$.

An other interesting observation is that the virus induced effect on the inflammatory response in the allograft is only found when infectious virus is inoculated into the recipients. Inoculation of ultraviolet-inactivated virus does not lead to upregulation of the inflammatory response. This observation corresponds with previous experiments in our lab (18) showing that indeed a generalized infection is important for induction of chronic rejection symptoms in the allografts. In these experiments the RCMV - induced effect was only observed when 5 Gy total body irradiation and $10^{5} \mathrm{PFU}$ RCMV was given to the animals. Using lower dosages of immunosuppression, i.e. $3 \mathrm{~Gy}$ total body irradiation, or no immunosuppression, no virus induced effect could be observed. An explanation for this phenomenon is that a generalized spread of the virus, with infections of almost all organs, is only found in the severely immunosuppressed host (24). In immunocompetent animals the infection is very limited and very low, or even undetectable, levels of the virus are found in all organs and by this way does not induce enhanced perivascular inflammation in the allografts.

In summary, active CMV infection leads to enhanced perivascular inflammation, characterized by an increased influx of T lymphocytes, enhanced expression of IL-2 receptor and MHC class II antigens. No direct correlation between increased inflammatory influx and neointima formation was found.

Future studies analyzing the role of monocytes/macrophages and their products and $\mathrm{T}$ lymphocytes should contribute to the understanding of the effect of infection on chronic rejection.

\section{REFERENCES}

1. Ho M (1994) Advances in understanding cytomegalovirus infection after transplantation. Transplant Proc, 26:7-11.

2. Steinhoff G, Behrend M, Wagner TO, Hoper MH, Haverich A (1991) Early diagnosis and effective treatment of pulmonary CMV infection after lung transplantation. J Heart Lung Transplant, 10:9-14.

3. Hayry P, Mennander A, Raisanen A, et al. (1993) Pathophysiology of vascular wall changes in chronic allograft rejection. Transplantation Reviews, 7:1-20.

4. Hayry P, Myllarniemi M, Aavik E (1996) Chronic allograft rejection. Transplant Proc, 28:2337-8.

5. Loebe M, Schuler S, Spiegelsberger S, Warnecke H, Fleck E, Hetzer R (1990) [Cytomegalovirus infection and coronary sclerosis after heart transplantation] Cytomegalievirus-Infektion und Koronarsklerose nach Herztransplantation. Dtsch Med Wochenschr, 115:1266-9. 
6. Hruban RH, Wu TC, Beschomer WE, et al. (1990) Cytomegalovirus nucleic acids in allografted hearts [letter]. Hum Pathol, 21:981-2.

7. Grattan MT, Moreno Cabral CE, Starnes VA, Oyer PE, Stinson EB, Shumway NE (1989) Cytomegalovirus infection is associated with cardiac allograft rejection and atherosclerosis. Jama, 261:3561-6.

8. McDonald K, Rector TS, Braulin EA, Kubo SH, Olivari MT (1989) Association of coronary artery disease in cardiac transplant recipients with cytomegalovirus infection. Am J Cardiol, 64:359-62.

9. Lemström KB, Bruning JH, Bruggeman CA, Lautenschlager IT, Hayry PJ (1993) Cytomegalovirus infection enhances smooth muscle cell proliferation and intimal thickening of rat aortic allografts. J Clin Invest, 92:54958.

10. Gao SZ, Hunt SA, Schroeder JS, Alderman EL, Hill IR, Stinson EB (1996) Early development of accelerated graft coronary artery disease: risk factors and course. J Am Coll Cardiol, 28:673-9.

11. Billingham ME (1992) Histopathology of graft coronary disease. J Heart Lung Transplant, 11:S38-44.

12. Foegh ML (1990) Chronic rejection--graft arteriosclerosis. Transplant Proc, 22:119-22.

13. Mennander A, Tiisala S, Halttunen J, Yilmaz S, Paavonen T, Hayry P (1991) Chronic rejection in rat aortic allografts. An experimental model for transplant arteriosclerosis. Arterioscler Thromb, 11:671-80.

14. Lemström K, Koskinen P, Krogerus L, Daemen M, Bruggeman C, Hayry P (1995) Cytomegalovirus antigen expression, endothelial cell proliferation, and intimal thickening in rat cardiac allografts after cytomegalovirus infection. Circulation, 92:2594-604.

15. Steinhoff G, You XM, Steinmuller C, et al. (1996) Enhancement of cytomegalovirus infection and acute rejection after allogeneic lung transplantation in the rat. Transplantation, 61:1250-60.

16. Martelius T, Krogerus L, Hockerstedt K, Makisalo H, Bruggeman C, Lautenschlager I (1997) CMV causes bile duct destruction and arterial lesions in rat liver allografts. Transplant Proceedings (in press).

17. Lautenschlager I, Hockerstedt K, Taskinen E, von Willebrand E (1996) Increased expression of adhesion molecules in liver allografts during cytomegalovirus infection. Transpl Immunol, 4:59-60.

18. Li F, Grauls G, Yin M, Bruggeman C (1996a) Correlation between the intensity of cytomegalovirus infection and the amount of perivasculitis in aortic allografts. Transpl. Int., 9:S340-S344.

19. Li F, Ming Y, Dam van JG, Grauls G, Rozing J, Bruggeman CA (1997) Cytomegalovirus infection enhances the neointima formation in rat aortic allografts: the effect of major histocompatibility antigen differences. Submitted for publication.

20. Bruggeman CA (1997) Role of CMV infection in vessel wall pathology. In: Hajjar D, Schwartz S, eds. The Role of Vascular Viral Infections in Atherosclerosis: Harwood Academic Publishers, in press.

21. Li F, Grauls G, Yin M, Bruggeman CA (1995) Initial endothelial injury and cytomegalovirus infection accelerate the development of allograft arteriosclerosis. Transplant Proc, 27:3552-4.

22. Bruggeman CA, Debie WM, Grauls G, Majoor G, van Boven CP (1983) Infection of laboratory rats with a new cytomegalo-like virus. Arch Virol, 76:189-99.

23. Bruggeman CA, Meijer H, Bosman F, van Boven CP (1985) Biology of rat cytomegalovirus infection. Intervirology, 24:1-9.

24. Stals FS, Bosman F, van Boven CP, Bruggeman CA (1990) An animal model for therapeutic intervention studies of CMV infection in the immunocompromised host. Arch Virol, 114:91-107.

25. Bruning JH, Persoons M, Lemström K, Stals FS, Clerq de E, Bruggeman CA (1994) Enhancement of transplantation-associated athererosclerosis by CMV, which can be prevented by anti viral therapy in the form of HPMPC. Transplant International, 7:S365-

26. Bruggeman CA, Li F, Stals FS (1995) Pathogenicity: animal models. Scand J Infect Dis Suppl, 99:43-50.

27. Lemström KB, Bruning JH, Bruggeman CA, Lautenschlager IT, Hayry PJ (1994) Triple drug immunosuppression significantly reduces immune activation and allograft arteriosclerosis in cytomegalovirusinfected rat aortic allografts and induces early latency of viral infection. Am J Pathol, 144:1334-47.

28. Lautenschlager I, Soots A, Krogerus L, et al. (1997) CMV increases inflammation and accelerates chronic rejection in rat kidney allografts. Transplantation Proceedings, 29:802-803.

29. Carlquist JF, Shelby J, Shao YL, Greenwood JH, Hammond ME, Anderson JL (1993) Accelerated rejection of murine cardiac allografts bymurine cytomegalovirus-infected recipients. Lack of haplotypespecificity. J Clin Invest, 91:2602-8.

30. Kishimoto T (1989) The Biology of interleukin-6. Blood, 74:1. 


\section{Chapter 5}

31. Hirano T, Akira S, Tagat, Kishimoto T (1990) Biological and clinical aspects of interleukin-6. Immunology Today:443-449.

32. Humbert M, Delattre RM, Fattal S, et al. (1993) In situ production of interleukin-6 within human lung allografts displaying rejection or cytomegalovirus pneumonia. Transplantation, 56:623-7.

33. Okada M, Kitahara M, Kishimoto T, Matsuda T, Hirano T (1988) IL-6/BSF-2 functions as a killer helper factor in the in vitro induction of cytotoxic T-cells. J. Immunology, 141:1543.

34. Lemstőm KB, Aho PT, Bruggeman CA, Hayry PJ (1994) Cytomegalovirus infection enhances mRNA expression of platelet-derived growth factor-BB and transforming growth factor-beta 1 in rat aortic allografts. Possible mechanism for cytomegalovirus-enhanced graft arteriosclerosis. Arterioscler Thromb, 14:2043-52.

35. Springer TA (1990) Adhesion receptors of the immune system. Nature, 346:425-434.

36. Cosimi AB, Cont D, Delmonico FL, et al. (1990) In vivo effects of monoclonal antibody to ICAM-1 (CD54) in nonhuman primates with renal allografts. J. Immunology, 144:4604-4612.

37. Isobe $\mathrm{M}$, Yagita $\mathrm{H}$, Okumura $\mathrm{K}$, Ihara $\mathrm{A}$ (1992) Specific acceptance of cardiac allograft after treatment with antibodies to ICAM-1 and LFA-1. Science, 255:1125-.

38. Span AH, Mullers W, Miltenburg AM, Bruggeman CA (1991) Cytomegalovirus induced PMN adherence in relation to an ELAM-1 antigen present on infected endothelial cell monolayers. Immunology, 72:355-60.

39. Waldman WJ, Adams PW, Orosz CG, Sedmak DD (1992) T lymphocyte activation by cytomegalovirusinfected, allogeneic cultured human endothelial cells. Transplantation, 54:887-96.

40. Watanabe M, Ito M, Kamiya H, Sakurai M (1996) Adherence of peripheral blood leukocytes to cytomegalovirus-infected fibroblasts. Microbiol Immunol, 40:519-23.

41. Steinhoff G, You XM, Steinmuller C, et al. (1995) Induction of endothelial adhesion molecules by rat cytomegalovirus in allogeneic lung transplantation in the rat. Scand J Infect Dis Suppl, 99:58-60.

42. Koffron AJ, Mueller KH, Kaufman DB, Stuart FP, Patterson B, Abecassis MI (1995) Direct evidence using in situ polymerase chain reaction that the endothelial cell and T-lymphocyte harbor latent murine cytomegalovirus. Scand J Infect Dis Suppl, 99:61-2.

43. van Dorp WT, Jonges E, Bruggeman CA, Daha MR, van Es LA, van Der Woude FJ (1989) Direct induction of MHC class I, but not class II, expression on endothelial cells by cytomegalovirus infection. Transplantation, 48:469-72.

44. Sedmak DD, Knight DA, Vook NC, Waldman JW (1994) Divergent patterns of ELAM-1, ICAM-1, and VCAM-1 expression on cytomegalovirus-infected endothelial cells. Transplantation, 58:1379-85.

45. Ustinov J, Loginov R, Bruggeman C, Suni J, Hayry P, Lautenschlager I (1994) CMV-induced class II antigen expression in various rat organs. Transpl int, 7:302-8.

46. Ustinov J, Bruggeman C, Hayry P, Lautenschlager I (1994) Cytomegalovirus-induced class II expression in rat kidney. Transplant Proc, 26:1729.

47. Kirkman RL, Barret LV, Gaulton GN, Kelley VE, Ythier A, Strom TB (1985) Administration of an anti-interleukin-2 receptor monoclonal antibody prolongs cardiac allograft survival in mice. J. Exp. Med., 162:358360.

48. Tullius SG, Tilney NL (1995) Both alloantigen-dependent and -independent factors influence chronic allograft rejection. Transplantation, 59:313-8.

49. von Willebrand E, Pettersson E, Ahonen J, Hayry P (1986) CMV infection, class II antigen expression, and human kidney allograft rejection. Transplantation, 42:364-7.

50. Dam van JG, Damoiseaux JGMC, Heijden van der HAMD, Grauls G, Breda Vriesman van PJC, Bruggeman CA (1997) Persistence of rat cytomegalovirus in the immunocompromised host: induction of anergy as a possible mechanism for immune evasion. Clinical and Experimental Immunology.

51. You XM, Steinmuller C, Wagner TO, Bruggeman CA, Haverich A, Steinhoff G (1996) Enhancement of cytomegalovirus infection and acute rejection after allogeneic lung transplantation in the rat: virus-induced expression of major histocompatibility complex class II antigens. J Heart Lung Transplant, 15:1108-19.

52. Ming Y, Fengling L, Dam van JG, G. G, Bruggeman CA (1997) Synergistic effect of cytomegalovirus infection and prolonged cold ishemia on the development of chronic rejection of rat kidney allografts. submitted for publication. 


\section{6}

CYTOMEGALOVIRUS INFECTION ENHANCES THE NEOINTIMA FORMATION IN RAT AORTIC ALLOGRAFTS: EFFECT OF MAJOR HISTOCOMPATIBILITY COMPLEX CLASS I AND CLASS II ANTIGEN DIFFERENCES 


\section{ABSTRACT}

Background: The development of chronic rejection has emerged as a major cause of long-term graft failure. Previous studies have demonstrated that cytomegalovirus (CMV) infection is associated with an increased incidence of chronic allograft rejection in renal, cardiac and aortic allografts. This study was designed to investigate the effects of the major histocompatibility complex (MHC) class I or class II mismatches on CMV-enhanced chronic rejection.

Methods: Aortic transplantation was performed between different inbred rat strain combinations; the Lewis to RP combination was class I-mismatched and Wag/Rij to RP class II-mismatched. At 7, 28 and 90 days after transplantation, the intensity of chronic rejection in either mismatched grafts with or without CMV infection was evaluated using histological and immunohistological analysis.

Results: The results of this study demonstrated that CMV infection led to an increased influx of monocytes/macrophages in class I-mismatched grafts at 1 week after transplantation and enhanced infiltration of T lymphocytes in class II-mismatched grafts at 4 weeks. Although more vascular lesions were observed in the class II-mismatched combinations, an intensified neointima formation by CMV infection was only observed in the MHC class I-mismatched allografts.

Conclusions: CMV infection may increase neointima formation of allografts when a MHC class I disparity between donor and recipient is present. This may be associated with increased perivascular influx of monocytes/macrophages observed in CMV-infected animals early after transplantation. 


\section{INTRODUCTION}

Transplantation-associated coronary artery disease is the leading cause of death on the long run in cardiac allograft recipients. The phenomenon is also called chronic rejection or transplant arteriosclerosis and is characterized by the occurrence of a diffuse concentric intimal proliferation in arteries and arterioles of the graft (1-4). It occurs not only in cardiac allografts but also in kidney, lung and liver allografts and has been called chronic rejection, obliterative bronchiolitis and vanishing bile duct syndrome, respectively $(5,6)$.

The underlying pathophysiologic mechanism of chronic rejection is still unclear. Among the risk factors, histoincompatibility is thought to be the most important, since it has been shown that in syngeneic transplants, no or very minor chronic rejection changes occurred (7). Therefore, chronic rejection is most likely caused by immunologic injury closely related to histoincompatibility between graft and host.

There is a strong clinical evidence that CMV infection plays an important role in the development of chronic rejection (8-10). However, a correlation between the CMV infection and the occurrence of transplant arteriosclerosis is still a controversial issue $(4,11,12)$.

The effect of CMV infection on the development of chronic rejection has been previously studied using a rat transplant model. Using rat-specific cytomegalovirus (RCMV) in this model (13), a virus-induced effect was observed in different transplant organs, e.g. kidney, liver, lung and heart (14-17). The aortic transplant model in rats, developed by Mennander et al (18), is often used in exploring the mechanisms involved in chronic rejection, because to its simplicity. In this model, a persistent perivascular inflammatory response occurred in allografts and was followed by the formation of a neointima. RCMV infection of the recipients accelerated this process and led to an enhanced smooth muscle cell proliferation and intimal thickening (19-22). Although the mechanism of CMV infection in the enhanced chronic rejection is not yet understood, it is clear that differences in major histocompatibility complex antigens between donor and recipient are essential, since in syngeneic grafts no CMV-induced effect was found. This leads to a hypothesis that CMV infection may modulate the allorecognition and reaction process, resulting in an enhanced immune response.

Up to now, in all experiments regarding the effects of RCMV infection, allografts were exchanged between rat strains that differed in both MHC class I and II antigens (19, 21, 22). Since it has been shown in a bone marrow transplantation model in mice that CMV infection enhanced graft-versus-host reaction, especially when there were MHC class I disparities $(23,24)$. The question was then asked whether a similar phenomenon could occur in the genesis of CMVenhanced chronic rejection (or immune reaction). To answer this question, we chose two rat strain combinations that were different in either MHC class I or class II antigens and used a previously described rat aortic transplant model with or without RCMV infection (25). The results of the present study show a more enhanced neointima formation in the MHC class Imismatched grafts by RCMV infection, which might be associated with $\mathrm{CMV}$-induced early increase in perivascular infiltration of monocytes/macrophages. 


\section{MATERIALS AND METHODS}

\section{Animals}

Inbred male RP (RTI $)$, Wag/Rij $\left(\mathrm{RT}^{4}\right)$ and Lewis (Lew/N; $\mathrm{RT}_{11}$ ) rats, weighing 250-300 g, were used in the study. The Lewis and RP rats were obtained from the Central Animal Facility of the Maastricht University, The Netherlands. The Wag/Rij rats were purchased from Harlan (Horst, The Netherlands B.V.). The RP strain is a natural MHC-recombinant strain. Originally the MHC loci of the RP strain were characterized using classical serological and cellular typing techniques (26). More recently our earlier findings on the class $\mathrm{I}^{\mathrm{U}}$ and $\mathrm{II}^{1}$ haplotype designation of the RP strain were confirmed using RT1 haplotype specific monoclonal antibodies for the various loci (Rozing et al., unpublished results), as well as using molecular DNA sequence analysis procedures in defining the distribution of Tap2 alleles among laboratory rat RT1 haplotypes (26). The RT1 ${ }^{p}$ haplotype of the RP strain shares MHC class $\mathrm{I}^{\mathrm{u}}$ antigens with the Wag/Rij strain and MHC class II $^{1}$ antigens with the Lewis strain (27). Transplantation with MHC class I difference between donor and recipient was achieved by implanting a segment of abdominal aorta of Lewis origin into an RP recipient rat. In the MHC class II-mismatched combination the aorta was obtained from a Wag/Rij rat and transplanted into an RP rat. The animals were housed under standardized conditions, fed with commercially available pellet diet and had free access to acidified ( $\mathrm{pH} 3$ ) demineralized water.

\section{Aortic transplantation}

Aortic grafting was performed as described previously (25). Briefly, rats were anaesthetized with ether for induction, then with phenobarbital $(5 \mathrm{mg} / 100 \mathrm{~g}$ body weight $)$ intraperitoneally for maintenance. The abdominal aorta between the left renal artery and the bifurcation was prepared in the donor rat. After intravenous administration of $50 \mathrm{U}$ of heparin, a segment of the abdominal aorta $(1.5-2 \mathrm{~cm})$ was removed. The aortic allograft was transplanted orthotopically (end-to-end anastomosis) into the recipient rat using 8-0 continuous nylon suture. Total ischemic time varied from 30 to 40 minutes, during which the graft was kept cold using $4^{\circ} \mathrm{C}$ phosphate buffered saline.

\section{Virus}

The Maastricht strain of RCMV (28) used in this study consisted of a pool of homogenated salivary glands of acutely infected rats (13). The rats in the virus-infected group were inoculated intraperitoneally with $10^{5}$ plaque forming units of salivary gland-derived RCMV. The inoculum was diluted in $1 \mathrm{ml}$ of Eagle's minimal essential medium containing $2 \%$ newborn calf serum.

\section{Experimental design}

All recipients received a sublethal total body irradiation ( $5 \mathrm{~Gy}$ ) on day 1 after transplantation, as described previously (28). This method of immune suppression is standardized for the animals used in our infection experiments and is routinely used in order to enhance the replication and spread of RCMV in adult rats $(13,28)$. The recipient rats were randomly allocated into several experimental groups, as summarized in Table 1. Each group contained at least 5 animals. The rats in the RCMV-infected groups were inoculated intraperitoneally with $10^{5}$ plaque forming units 
of RCMV at 6 hours after total body irradiation. The animals in the noninfected groups were left noninoculated with otherwise similar diets and conditions. The recipients were sacrificed on day 7,28 and 90 after transplantation. Aortic grafts and other organs were removed and processed for frozen and paraffin sections or for plaque assay.

\section{Virus detection by immunohistochemistry and plaque assay}

For detection of early and late RCMV antigens, immunohistochemical techniques were used with anti-RCMV monoclonal antibodies (mAbs) $(29,30)$. For this purpose $4 \mu \mathrm{m}$-thick paraffinembedded sections were used. After blocking endogenous peroxidase with $0.6 \% \mathrm{H}_{2} \mathrm{O}_{2}$, deparaffinized tissue sections were preincubated with $2 \%$ bovine serum albumin before incubation with a mixture of mouse mAbs 8 and 35 directed against nuclear and cytoplasmic RCMV antigens, repectively (30). A second incubation was performed with biotinylated affinitypurified sheep anti-mouse IgG antibodies (Amersham, Netherlands), followed by incubation with streptavidin-horseradish peroxidase complex (Amersham, Netherlands). Specific antibodyantigen binding was visualized with 3,3-diaminobenzidine substrate. As a control of specific positive staining, all sections were incubated with an irrelevant $\mathrm{mAb}$. Tissue sections were counterstained with haematoxylin and embedded in Entellan (Merck).

For detection of systemic infection, infectious virus in other organs, i.e., spleen, liver and salivary gland from recipient was tested using the plaque titration assay (13). The tissue samples of these organs were taken aseptically in culture medium when the animals were killed, homogenized in a tissue grinder and suspended in minimal essential medium with $2 \%$ fetal calf serum. For this, 10 -fold dilutions of $10 \%$ homogenates (wt/vol) were inoculated on confluent rat embryonal fibroblast monolayers. After 7 days of incubation, the number of plaques was monitored microscopically after fixation and methylene blue staining.

\section{Immunohistochemistry}

Immunohistochemical stainings were performed using the two-layer indirect immunoperoxidase staining technique. Dry acetone-fixed cryostat sections (four micron thick) were incubated with the primary mouse mAbs and, after washing, a rabbit anti-mouse peroxidase labeled secondary antibody (Amersham, Netherlands) was placed on the sections. The sections were then treated by the peroxidase substrate solution as described above (see Virus detection). The following mAbs used in the study were purchased from Sera-lab (Crawley Down, UK): W3/25, a mouse IgG1 mAb to rat $\mathrm{CD}^{+}$cells; $\mathrm{Ox}-8$, a mouse IgG1 mAb to rat $\mathrm{CD}^{+}$cells; $\mathrm{Ox}-39$, a mouse $\mathrm{mAb}$ to rat interleukin-2 receptor; Ox-6, a mouse IgG1 mAb to rat MHC class II antigen. ED1 (a mouse mAb to inflammatory monocytes/macrophages) and ED 2 (a mouse mAb to resident macrophages) were kindly supplied by Prof. Dr. C. Dijkstra (Department of Cell Biology and Immunology, Free University, Amsterdam, The Netherlands). The mAbs for detection of natural killer cells (3.2.3), rat lymphocyte function-associated antigen-1 and intercellular adhesion molecule-1 were kindly supplied by Dr. Masayuki (Department of Bioregulation, Biochemical research center, Osaka University, Medical School, Japan). To control the specificity of signals, the same procedures were performed with irrelevant antibodies. 


\section{Chapter 6}

\section{Quantification of immunohistochemistry}

Quantification of immunohistochemistry was performed semiquantitatively by scoring the staining from 0 to $5(0=$ no positive staining; $1=$ very weak, $2=$ weak, $3=$ moderate, $4=$ intense and $5=$ very intensive staining). The evaluation of intensity of positive staining was focused on vascular cells (smooth muscle cells and endothelial cells) and on infiltrating leukocytes in intima, media and adventitia. Scoring was done independently by two investigators.

\section{Morphometric analysis}

A segment of the graft, fixed in $3.7 \%$ buffered formalin, was embedded in paraffin. The aortas from nontransplanted rats were used as normal controls. Four $4-\mu \mathrm{m}$-thick sections were taken from different levels of each paraffin-embedded graft and evaluated by morphometry. The crosssectional areas of intima and media of the aortic grafts were measured with a computer-assisted morphometry system (Quantimet, 570; Leica). The results of the measurements are expressed as $\mu \mathrm{m}^{2}$. The cross-sectional area of the media was defined as the area between the external and internal elastic lamina. The neointima area was defined as the area between the internal elastic lamina and the arterial lumen as described previously (21). The unit of areas was $\mu \mathrm{m}^{2}$.

\section{Statistics}

Data from morphometric analysis and semiquantitative immunohistochemical evaluation are expressed as mean \pm SEM. One-way nonparametric analysis of variance was used to determine statistical significance between different groups. $\mathrm{P}$ values $<0.05$ were regarded as significant different.

\section{RESULTS}

\section{Systemic infection in allograft recipients}

The allograft recipients inoculated with RCMV did not show any clinical symptoms of CMV disease. All salivary glands of the infected rats contained infectious virus as shown by plaque assay and immunohistochemistry at day 28 and day 90 after inoculation. No significant differences in the amount of RCMV in the salivary glands between the animals of the MHC class I- and class II-disparate combinations were observed. In noninfected rats, no RCMV antigens or infectious virus was detectable in the salivary glands.

\section{RCMV infection in aortic allografts}

No RCMV-positive endothelial cells or smooth muscle cells were detected at any time point measured. At day 7, very weak RCMV-positive signals were observed in aortic allografts of all infected rats. While in the grafts of noninfected groups, no RCMV signal was detectable. At days 28 and 90, no RCMV-positive staining was found in the aortas of any of the animals studied. The sporadic RCMV-positive cells detected at day 7 after-inoculation were seen only in the perivascular area, which consisted mainly of mononuclear cells and occasionally of fibroblasts. There were no significant differences in intensity of RCMV signals between the animals of MHC class I- and II-mismatched groups. 

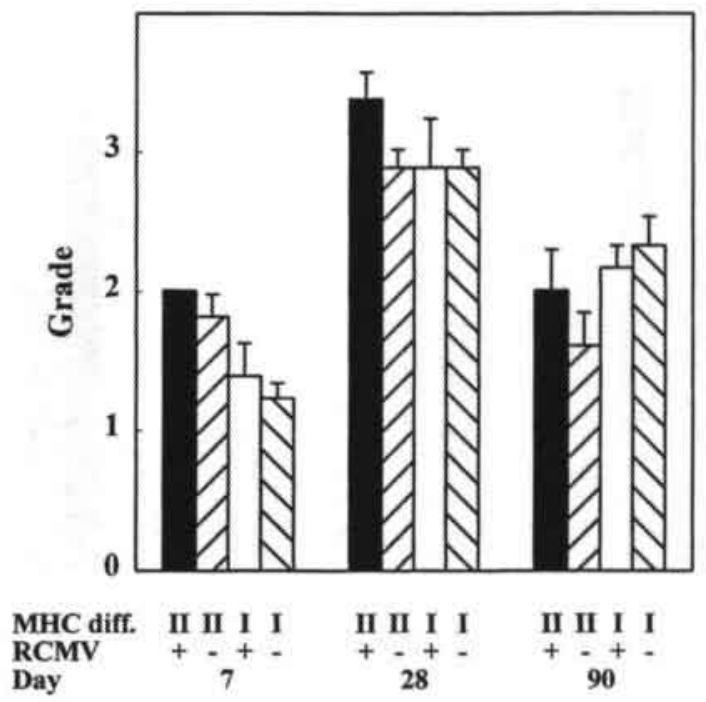

Fig. 1. Effect of CMV infection on influx of leukocytes in the perivascular areas of transplanted aortas with MHC class I or II mismatches. The semiquantitative evaluations were performed in H\&E stained cross sections of aortic allografts, as detailed in Materials and Methods. Data are expressed as mean $\pm S E M$.

\section{Effect of RCMV infection on the inflammatory response in grafts}

An influx of inflammatory cells was observed in the perivascular area (adventitia) of aortic allografts of all groups. Nearly no influx of inflammatory cells could be seen in intima and media of grafts and in autologous part of the aorta. Although the perivascular inflammation persisted throughout the experimental period ( 90 days), the extent of the inflammatory response was higher at day 28 compared with days 7 and 90 in both class I- and II-disparate strain combinations, regardless of wether there was CMV infection (Fig. 1).

The cellular influx in the adventitia consisted of $\mathrm{CD}^{+}$and $\mathrm{CD}^{+} \mathrm{T}$ cells and of monocytes/macrophages stained with anti-ED1 and anti-ED2 mAbs. On day 28, when the inflammatory response was the highest, a significant increased infiltration of $\mathrm{CD}^{+}$and $\mathrm{CD} 8^{+} \mathrm{T}$ cells in RCMV-infected rats was observed when MHC class II mismatches were present (Fig. 2). Effects of $\mathrm{CMV}$ infection on $\mathrm{ED}^{+}$and $\mathrm{ED} 2^{+}$monocytes/macrophages in the adventitia of grafts were shown in Figure 3. A significantly enhanced infiltration of monocytes/macrophages by CMV infection was seen in MHC class I-mismatched grafts at day 7 after transplantation, but not in class II mismatched grafts. No natural killer cells were detected in the allografts of any groups. The expression of intercellular adhesion molecule-1, lymphocyte function-associated antigen-1 and MHC class II antigen and the extent of interleukin-2 Receptor ${ }^{+}$cells in aortic allografts also peaked at day 28 . There were no significant differences between the CMV-infected and noninfected rats in either mismatched combinations. 
Nilling

Nllibio 


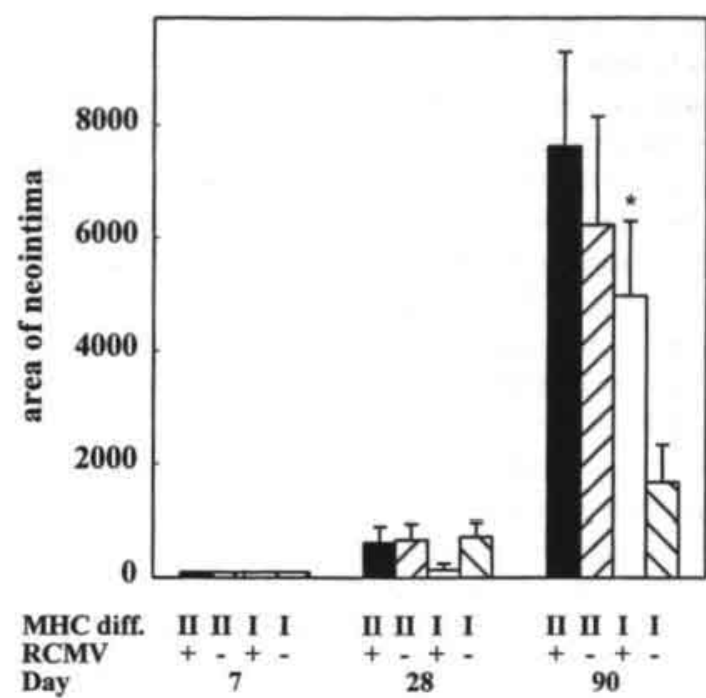

Fig. 4. Effect of CMV infection on neointima formation of aortic allografts. The neointima was measured by means of image analysis, as detailed in Materials and Methods. Data are expressed as mean $\pm S E M * P<0.05$ compared with the non-infected rats of the same strain combination on the same posttransplant day (one-way analysis of variance).

\section{Effect of RCMV infection on the neointima formation}

As shown in Figure 4, a thin neointima was seen in the allografts at 28 days after transplantation. The neointima formation became more obvious at day 90 . At this time point, the development of neointima formation in MHC class I mismatched grafts was significantly lower than that in class II-mismatched group. However, an enhanced intimal proliferation by CMV infection was only observed in MHC class I-mismatched allografts $(\mathrm{P}<0.05)$.

No significant differences were found in the medial area of the allografts studied at the different measure points.

\section{DISCUSSION}

Chronic rejection or transplant arteriosclerosis is a diseased process of multiple etiology that is influenced by a variety of risk factors. Histoincompatibilty is thought to be one of the most important risk factors (5), since in syngeneic transplants no or very minor lesions were seen. The role of CMV infection in the pathogenesis of chronic rejection was observed in humans (8-10) and animals $(17,19-21,31)$. In the rat experiments using DA to WF and BN to Lewis strain combinations, which differed in both MHC class I and II antigens and in non-MHC antigens, enhancements of smooth muscle cell proliferation, intimal thickening and perivascular inflammation were observed in aortic allografts of CMV-infected compared with noninfected recipients. The present study was designed to compare the detrimental effect of RCMV infection on the pathogenesis of chronic rejection of MHC class I-mismatched aortic allografts with that of MHC class II-mismatched grafts. A significantly increased intimal proliferation and thickening 


\section{Chapter 6}

by systemic CMV infection was observed in MHC class I-mismatched aortic allografts, but not in class II-mismatched transplants.

The common manifestation of chronic rejection is characterized by the formation of a neointima in the graft, a process that is preceded by perivascular inflammation. The precise mechanism underlying the association of CMV with enhanced neointima formation is unclear. In general, it is accepted that the perivascular inflammation occurring after allograft transplantation is the most important factor. In the present study, the enhanced neointima formation by $\mathrm{CMV}$ infection in the class I-mismatched grafts seems to be related to the CMV-induced elevation of perivascular infiltrate of monocytes/macrophages early after transplantation, suggesting an important role of early influx of monocytes/macrophages in the CMV-modulated process. The contribution of these cells on the development of the neointima is not clear. Several studies demonstrated that macrophages, cells known to be involved in transport and spread of the virus (32), play a role in the development of arteriosclerotic lesions $(33,34)$ and that the influx of especially monocytes/macrophages in grafts is upregulated in CMV-infected recipients (19). Recently, Steinmuller et al. (35) also showed that CMV infection in allografts resulted in an increased number of activated macrophages. Reduction of monocytes/macrophages by chemical compounds led to a decrease in the neointima formation (36), suggesting that these cells are important in the migration and proliferation of smooth muscle cells. Macrophages are known to be producers of several growth factors, such as platelet-derived growth factor, which are important mediators for smooth muscle cell proliferation. Enhanced mRNA expression of these growth factors was found in rat aortic allografts (37).

In this study, $\mathrm{CD}^{+}$and $\mathrm{CD} 8^{+} \mathrm{T}$ lymphocytes were also largely present in the perivascular area of all allografts, and CMV infection of the host leads to an increased influx of the T lymphocytes in class II-mismatched grafts on day 28. However, this CMV-enhanced infiltration of T cells did not lead to a significant enlargement of the neointima compared to the noninfected group. It is also interesting to note that the MHC class I-mismatched grafts developed relatively fewer vascular lesions than the class II-disparate combinations, suggesting that MHC class II disparity may contribute more to the development of this disease process. However, a deteriorate effect of CMV infection on neointima formation was observed only in the class I-disparate grafts, and not in the aortas of animals with class II disparity. Although we cannot exclude the possibility that the differential effect of CMV infection on the increase of neointima formation in the Lewis to RP combination as compared to the WAG to RP combination is restricted only to these specific strain combinations, in our view, these results are most likely due to the partial MHC disparities between these rat strains and therefore strongly suggest that CMV infection has an enhancing effect only when differences in MHC class I are present between donor and recipient. More experiments in other strain combinations are obviously needed to strengthen this point. These data, moreover, are in agreement with data obtained in mouse experiments suggesting that in the rat model as well as in the mouse (37), CMV infection stimulates the alloreaction where a MHC class I disparity between donor and recipient is present.

Injection of virus into rats leads to a generalized infection in the immunocompromised animal, as shown by the presence of active virus and viral antigens in the salivary glands for several months. The presence of viable infectious virus in the host might be a prerequisite for the CMV induced effect on chronic rejection, since injection of (ultraviolet-irradiated) noninfectious virus did not lead to enhancement of chronic rejection (22). A very low level of active virus in the 
vessel wall cells, such as endothelial cells and smooth muscle cells, was detected early after the viral inoculation (first week). Thereafter, no signs of active infection were detectable since no viral antigens were found in vessel wall cells. Although active virus infection does not persist in the aorta, it can not be completely excluded that the CMV genome persists in a latent state in cells of the vessel wall $(38,39)$. Preliminary data in our laboratory using the polymerase chain reaction (PCR) demonstrated that indeed viral DNA persisted in the aortas of infected rats for at least five weeks after infection (to be published). Virus infections and especially CMV infections are known to have stimulatory effects on the immune system, especially the stimulation of lymphocyte functions. It has been found that CMV infection led to polyclonal cytotoxic $\mathrm{T}$ lymphocyte stimulation (39) and that CMV acted synergistically with $\mathrm{T}$ cell responses in mouse transplant models $(40,41)$. Treatment of the recipients with anti-CMV drugs minimized the enhanced effect of the virus infection on allograft neointima thickness (21).

An upregulation of intercellular adhesion molecule-1 and lymphocyte function-associated antigen-1 in grafts of CMV-infected recipients has previously been reported $(15,42,44,45)$. However, in this experiment with the two different stain combinations, an upregulation of expression of intercellular adhesion molecule-1 is found only at day 7, while no CMV- induced effect on expression of lymphocyte function-associated antigen- was observed.

In conclusion, exchange of allografts between rat strains that are different in either MHC class I or class II antigens leads to intimal proliferation. CMV infection may stimulate this process only when there are MHC class I mismatches, which may be associated with CMV-enhanced perivascular influx of monocytes/macrophages early after transplantation. Further studies are needed to confirm the finding and address mechanism of action of CMV infection on transplant arteriosclerosis with different histocompatibility barriers.

\section{REFERENCES}

1. Billingham ME. Histopathology of graft coronary disease. J Heart Lung Transplant 1992: 11 (3 Pt 2): S38.

2. Hosenpud JD, Hershberger RE, Ratkovec RR, et al. Methotrexate for the treatment of patients with multiple episodes of acute cardiac allograft rejection. J Heart Lung Transplant 1992: 11 (4 Pt 1): 739.

3. Gao SZ, Hunt SA, Schroeder JS, Alderman EL, Hill IR, Stinson EB. Early development of accelerated graft coronary artery disease: risk factors and course. J Am Coll Cardiol 1996: 28: 673.

4. Sharples LD, Caine N, Mullins P, et al. Risk factor analysis for the major hazards following heart transplantation-rejection, infection, and coronary occlusive disease. Transplantation 1991: 52: 244.

5. Hayry P, Mennander A, Raisanen A, et al. Pathophysiology of vascular wall changes in chronic allograft rejection. Transplantation Reviews 1993: 7:1.

6. Hayry P, Myllarniemi M, Aavik E. Chronic allograft rejection. Transplant Proc 1996: 28: 2337.

7. Cramer DV, Qian SQ, Harnaha J, et al. Cardiac transplantation in the rat. I. The effect of histocompatibility differences on graft arteriosclerosis. Transplantation 1989: 47: 414.

8. Grattan MT, Moreno Cabral CE, Starnes VA, Oyer PE, Stinson EB, Shumway NE. Cytomegalovirus infection is associated with cardiac allograft rejection and atherosclerosis. JAMA 1989:261:3561.

9. Loebe M, Schuler S, Spiegelsberger S, Warnecke H, Fleck E, Hetzer R. Cytomegalovinus infection and coronary sclerosis after heart transplantation. Dtsch Med Wochenschr 1990: 115: 1266

10. McDonald K, Rector TS, Braulin EA, Kubo SH, Olivari MT. Association of coronary artery disease in cardiac transplant recipients with cytomegalovirus infection. Am J Cardiol 1989: 64: 359.

11. Weimar W, Balk AH, Metselaar HJ, Mochtar B, Rothbarth PH. On the relation between cytomegalovirus infection and rejection after heart transplantation. Transplantation 1991: 52: 162.

12. Scott CD, Colquhoun IW, Gould K, Au J, Dark JD. Determinants of graft arteriosclerosis after heart transplantation. Transplant International 1992: 5: S238. 


\section{Chapter 6}

13. Bruggeman CA, Meijer H, Bosman F, van Boven CP. Biology of rat cytomegalovirus infection. Intervirology 1985: $24: 1$.

14. Steinhoff G, You XM, Steinmuller C, et al. Enhancement of cytomegalovirus infection and acute rejection after allogeneic lung transplantation in the rat. Transplantation 1996: 61: 1250.

15. Steinhoff G, You XM, Steinmuller C, et al. Induction of endothelial adhesion molecules by rat cytomegalovirus in allogeneic lung transplantation in the rat. Scand J Infect Dis Suppl 1995: 99: 58.

16. Martelius T, Krogerus L, Hockerstedt K, Makisalo H, Bruggeman C, Lautenschlager I. CMV causes bile duct destruction and arterial lesions in rat liver allografts. Transplant Proceedings 1997: in press.

17. Lautenschlager $\mathrm{I}$, Soots $\mathrm{A}$, Krogerus $\mathrm{L}$, et al. CMV increases inflammation and accelerates chronic rejection in rat kidney allografts. Transplantation Proceedings 1997: 29: 802.

18. Mennander A, Tiisala S, Halttunen J, Yilmaz S, Paavonen T, Hayry P. Chronic rejection in rat aortic allografts. An experimental model for transplant arteriosclerosis. Arterioscler Thromb 1991: 11: 671.

19. Lemström KB, Bruning JH, Bruggeman CA, Lautenschlager IT, Hayry PJ. Cytomegalovirus infection enhance smooth muscle cell proliferation and intimal thickening of rat aortic allografts. J Clin Invest 1993: 92: 549.

20. Lemström KB, Bruning JH, Bruggeman CA, Lautenschlager IT, Hayry PJ. Triple drug immunosuppression significantly reduces immune activation and allograft arteriosclerosis in cytomegalovirus-infected rat aortic allografts and induces early latency of viral infection. Am J Pathol 1994: 144: 1334

21. Bruning JH, Persoons M, Lemstrơm K, Stals FS, Clerq de E, Bruggeman CA. Enhancement of transplantationassociated athererosclerosis by CMV, which can be prevented by anti viral therapy in the form of HPMPC. Transplant International 1994; 7 (Suppl): S365

22. Li F, Grauls G, Yin M, Bruggeman C. Correlation between the intensity of cytomegalovinus infection and the amount of perivasculitis in aortic allografts. Transpl. Int. 1996: 9(Suppl): S340.

23. Cray C, Levy RB. The ability of murine cytomegalovirus and class I major histocompatibility complextirspanate parentali cellis to induce atterations characteristic of severe graft-versus-host reactions. Transplantation 1989: 48: 1057.

24. Cray C, Levy RB. CD8 + and CD4+ T cells contribute to the exacerbation of class I MHC disparate graft-vshost reaction by concurrent murine cytomegalovirus infection. Clin Immunol Immunopathol 1993: 67: 84 .

25. Li F, Grauls G, Yin M, Bruggeman CA. Initial endothelial injury and cytomegalovirus infection accelerate the development of allograft arterioscierosis. Transplant Proc 1995: 27: 3552.

26. Joly E, Deverson EV, Coadwell JW, Gunther E, Howard JC, Butcher GW. The distribution of Tap2 alleles among laboratory rat RT1 haplotypes. Immunogenetics 1994: 40 (1): 45-53.

27. Vaessen LMB, Hameijer LDF, Carpenter CB, Cramer DV, Rozing J. The R1-rat: a new RT1 haplotype. Tranplant. Proc. 1979: 11: 1565.

28. Bruggeman CA, Debie WM, Grauls G, Majoor G, van Boven CP. Infection of laboratory rats with a new cytomegalo-like virus. Arch Virol 1983: 76: 189.

29. Stals FS, Bosman F, van Boven CP, Bruggeman CA. An animal model for therapeutic intervention studies of CMV infection in the immunocompromised host. Arch Virol 1990: 114:91.

30. Bruning JH, Debie WH, Dormans PH, Meijer H, Bruggeman CA. The development and characterization of monoclonal antibodies against rat cytomegalovirus induced antigens. Arch Virol 1987: 94: 55.

31. Li F, Grauls G, van Dam JG, Yin M, and Bruggeman CA. Cytomegalovirus infection enhances the perivascular inflammatory reaction in transplanted aortic allografts. Cardiovascular Engineering 1997: 2: 207.

32. Michelson S. Interaction of human cytomegalovirus with monocytes/macrophages: a love-hate relationship. Path. Biol. 1997: 45: 146.

33. Cramer D, Chapman F, Wu G, Harnaha J, Qian S, Makowka L. Cardiac transplantation in the rat . II Alteration of the severity of donor graft arteriosclerosis by modulation of the host immune response. Transplantation 1990: 50: 554 .

34. Akyurek L, Paul L, Funa C, Larsson E, Fellstrom B. Smooth muscle cell migration into intima and adventitia during development of transplant vasculopathy. Transplantation 1996: 62: 1526.

35. Steinmuller C, Steinhoff G, Bauer D, et al. Analysis of leukocyte activation during acute rejection of pulmonary allografts in noninfected and cytomegalovirus-infected rats. J Leukoc Biol 1997: 61: 40.

36. Azuma H, Nadeau KC, Ishibashi M, Tilney NL. Prevention of functional, structural, and molecular changes of chronic rejection of rat renal allografts by a specific macrophage inhibitor. Transplantation 1995: 60: 1577. 
37. Via CS, Shanley JD, Shearer GM. Synergistic effect of murine cytomegalovinus on the induction of acute graft-vs-host disease involving MHC class I differences only. Analysis of in vitro T cell function. J Immunol $1990 ; 145: 3283$.

38. Yamashiroya HM, Ghosh L, Yang R, Robertson AL, Jr. Herpesviridae in the coronary arteries and aorta of young trauma victims. Am J Pathol 1988: 130: 71.

39. Hendrix MG, Salimans MM, van Boven CP, Bruggeman CA. High prevalence of latently present cytomegalovirus in arterial walls of patients suffering from grade III atherosclerosis. Am J Pathol 1990: 136: 23.

40. Yang $\mathrm{H}$, Welsh RM. Induction of alloreactive cytotoxic $\mathrm{T}$ cells by acute virus infection of mice. J Immunol 1986: 136: 1186.

41. Shanley JD, Via CS, Sharrow SO, Shearer GM. Interstitial pneumonitis during murine cytomegalovirus infection and graft-versus-host reaction. Characterization of bronchoalveolar lavage cells. Transplantation 1987: 44: 658 .

42. Grundy JE, Shanley JD, Shearer GM. Augmentation of graft-versus-host reaction by cytomegalovirus infection resulting in interstitial pneumonitis. Transplantation 1985: 39: 548.

43. Lemström KB, Aho PT, Bruggeman CA, Hayry PJ. Cytomegalovirus infection enhances mRNA expression of platelet-derived growth factor-BB and transforming growth factor-beta 1 in rat aortic allografts. Possible mechanism for cytomegalovirus-enhanced graft arteriosclerosis. Arterioscler Thromb 1994: 14: 2043

44. Koskinen PK. The association of the induction of vascular cell adhesion molecule-1 with cytomegalovirus antigenemia in human heart allografts. Transplantation 1993: 56: 1103.

45. Lautenschlager I, Hockerstedt K. Induction of ICAM-1 on hepatocytes precedes the lymphoid activation of acute liver allograft rejection and cytomegalovirus infection. Transplant Proc 1993: 25(1Pt2): 1429. 



\section{7}

EFFECTS OF CYTOMEGALOVIRUS INFECTION AND PROLONGED COLD ISCHEMIA ON CHRONIC REJECTION OF RAT RENAL ALLOGRAFTS. I. FUNCTIONAL AND MORPHOLOGICAL CHANGES 


\section{ABSTRACT}

Chronic rejection has emerged as a major cause of late renal graft loss. Among others, cytomegalovirus (CMV) infection and ischemic-reperfusion injury have been implicated as risk factors for chronic rejection. The purpose of this study was to investigate whether CMV infection and prolonged cold ischemia ( $24 \mathrm{~h})$ act synergistically on the progression of chronic rejection. Lewis recipients of renal allografts (with or without prolonged ischemic insults) from MHCincompatible Brown Norway rats were inoculated with rat cytomegalovirus (RCMV) or left noninfected. It was observed that CMV infection alone increased neointima formation and glomerular sclerosis, as well as enhanced influx of $\mathrm{CD}^{+}$and $\mathrm{CD}^{+}$cells and monocytes/macrophages in renal grafts. Prolonged cold ischemia led to dramatic tissue destruction and inflammation, higher serum creatinine levels and increased infiltration of natural killer cells. Combination of CMV infection and prolonged cold ischemia resulted in high creatinin excretion and morphological damage. This was associated with increased infiltration of $\mathrm{CD}^{+}$cells, monocytes/macrophages and natural killer cells and upregulated expression of MHC class II antigens. In conclusion, CMV infection or prolonged cold ischemia alone leads to different histological alterations of kidney allograft, combination of both factors has an additive effect on the diseased process in terms of deterioration of graft function.
\end{abstract}




\section{INTRODUCTION}

With the current immunosuppressive regimen, the incidence of graft loss due to acute rejection has been dramatically reduced. However, the expected half-life of the allograft has remained the same. This late allograft loss is mainly due to transplant arteriosclersosis, or so called "chronic rejection" (1). In kidney allografts, chronic rejection has been defined as progressive functional deterioration occurring months or years after engraftment and has proved resistant to therapeutic attempts. Although the pathogenesis of chronic rejection still remains largely unknown, several risk factors have been implicated, e.g. repeated episodes of acute rejection, viral infection, ischemia/reperfusion injury and loss of functional mass $(2,3)$.

In immunocompromised transplant recipients, CMV infection is the most common and important viral infection (4-6). There is evidence of CMV infection in up to two thirds of all recipients, although clinical disease does not occur in all the infected patients (7). Unfortunately, CMV infection has been found to be associated with the development of chronic rejection both clinically and experimentally $(5,8,9)$.

Donor kidneys usually undergo a period of warm and cold ischemia followed by reperfusion. Ischemia/reperfusion injury has also been found to play a role in chronic rejection $(2,5,10)$. Accordingly, the purpose of this study was to determine whether CMV infection and prolonged cold ischemia (CI) have an additive effect on the development of chronic allograft rejection, using a rat renal transplant model.

\section{MATERIALS AND METHODS}

\section{Animals and surgery}

All experiments were performed in accordance with the law according the protection of animals. The 'principles of laboratory animal care' (NIH publication No.85-23, revised 1985) were followed.

Specified pathogen free (SPF, according to the recommendations of the Federation of European Laboratory Animal Science Association) (11) inbred male Lewis (LEW; RT 11 ) and Brown Norway (BN/M; $\mathrm{RT}_{1 \mathrm{n}}$ ) rats (weighing 240-260 g), obtained from the Centralised Experimental Animal Facilities of the University of Maastricht were used throughout the study. The animals were housed under standardized conditions, fed with commercially available pellet diet and had free access to acidified demineralized water $(\mathrm{pH} \pm 3)$. Kidneys from Brown Norway rats were orthotopically transplanted into the MHC-incompatible Lewis rats, using a technique described previously (12). The right native kidney of the recipient was removed at the time of engraftment and the left 10 days later. The allograft recipients were treated with cyclosporin $\mathrm{A}(15 \mathrm{mg} / \mathrm{kg} / \mathrm{day}$, subcutaneously, Novartis, Switzerland) for 10 days to suppress an initial acute rejection episode (13).

\section{Experiment protocol}

The recipient rats were randomly allocated into 4 groups ( $n=6$, per group). In the control group (CI-CMV-), the donor kidneys were transplanted immediately into recipients. The renal allograft recipient in the second group (CI-CMV+) received an intraperitoneal inoculation of $10^{5}$ plaque 
forming units (PFU) of Maastricht stain RCMV $(14,15)$ on the day of transplantation. In the third group (CI+CMV-), renal allografts were stored for 24 hours in the University of Wisconsin solution $\left(4^{\circ} \mathrm{C}\right)$ before transplantation. In the fourth group $(\mathrm{CI}+\mathrm{CMV}+)$, the recipients received kidney allografts with 24 hours of CI and were subsequently injected with RCMV. Rats were sacrificed on day 10 or 60 after transplantation. Tissue samples of the renal allografts and other organs (livers, spleens and salivary glands) were removed and processed either for frozen and paraffin sections, or for plaque assay.

\section{Virus detection}

For the detection of systemic virus infection, the salivary glands, spleen and liver of the recipient were examined for the presence of infectious virus. The organs were homogenized in a tissue grinder and suspended in MEM with $2 \%$ foetal calf serum (FCS). Quantitation of infectious virus was done by means of plaque assay (14). For this, 10 -fold dilution of $10 \%$ homogenates (wt/vol) were inoculated on a confluent rat embryonal fibroblast monolayer. After 7 days of incubation, the number of plaques was monitored microscopically following fixation and methylene blue staining. For detection of RCMV antigens, $4 \mu \mathrm{m}$ thick formalin-fixed paraffin-embedded tissue sections were stained with RCMV monoclonal antibodies (16).

\section{Determination of serum creatinine}

Blood samples were taken from the 60-day surviving rats at days 7 and 14 (after the nephrectomy of the left native kidney) post transplantation and at sacrifice. Serum creatinine was measured to determine the function of the transplant kidney. Normal levels of serum creatinine were obtained by measuring the blood samples taken a few days before transplantation.

\section{Histological examination}

Formalin-fixed and paraffin embedded kidney specimens were stained with hematoxylin and eosin for routine histology and with elastic van Giesen for evaluation of vascular changes. The general histological changes in renal allografts were assessed semi-quantitatively in each section. Different parameters were scored blindly from 0 to $3(0=$ normal, $1=$ mild, $2=$ moderate, $3=$ severe changes), without knowledge of group assignment. The intensity of chronic changes in the transplants was then expressed, as a single numerical figure, by the chronic allograft damage index (CADI) which is the sum of 6 parameters: interstitial inflammation and fibrosis, glomerular mesangial matrix increase and sclerosis, vascular intimal proliferation, and tubular atrophy (17).

\section{Immunohistochemistry and quantitation}

Four-micron thick sections of frozen grafts were used for immunohistochemistry and stained with the two-layer indirect immunoperoxidase technique using monoclonal antibodies (mAbs). MAbs against $\mathrm{CD}^{+}$lymphocytes (W3/25) and CD8 ${ }^{+}$lymphocytes (OX-8) were obtained from Sera-Lab (Crawley Down, UK); mAbs against major histocompatibility complex (MHC) class II (OX-6) were provided by Serotec (Wiesbaden, Gemany); mAbs against monocyte/macrophages and dendritic cells (ED-1) were kindly supplied by Dr. Dijkstra (Dept. of Immunology, Free University, Amsterdam, The Netherlands); natural killer cell markers (3.2.3) were supplied by the Department of Pathology of the University of Leiden, The Netherlands. The polyclonal rabbit anti-mouse Ig peroxidase conjugated was purchased from DAKO (Denmark). Quantitation of 
positive immunohistochemical staining was done semiquantitatively by scoring the intensity of staining from 0 to 3 ( 0 = no visible staining, $1=$ few cells with faint staining, $2=$ moderate intensity with multifocal staining, 3 = intense diffuse staining of cells analysed). The evaluation of intensity of positive stained infiltrating leukocytes was focused on perivascular and interstitial areas. The analysis of expression of MHC class II antigens was focused on endothelial cells of arterioles.

\section{Statistics}

All data were presented as mean \pm SEM. The significance of the differences within one staining group were determined using the Kruskal-Wallis 1-way Anova. If this test revealed a significance, the differences between the groups were determined using the Mann-Whitney UWilcoxon Rank Sum W test. P-values $\leq 0.05$ were taken to be statistically significant.

\section{RESULTS}

\section{Systemic CMV infection in allograft recipients}

The allograft recipients inoculated with RCMV did not show any clinical symptoms of CMV disease. Infectious RCMV was, using plaque assays, detected in salivary glands of all the CMVinoculated recipients (CI-CMV+ and $\mathrm{CI}+\mathrm{CMV}+$ ) at days 10 and 60 , indicating a systemic $\mathrm{CMV}$ infection. No RCMV could be detected in any organ of the non-infected animals (CI-CMV- and CI+CMV-).

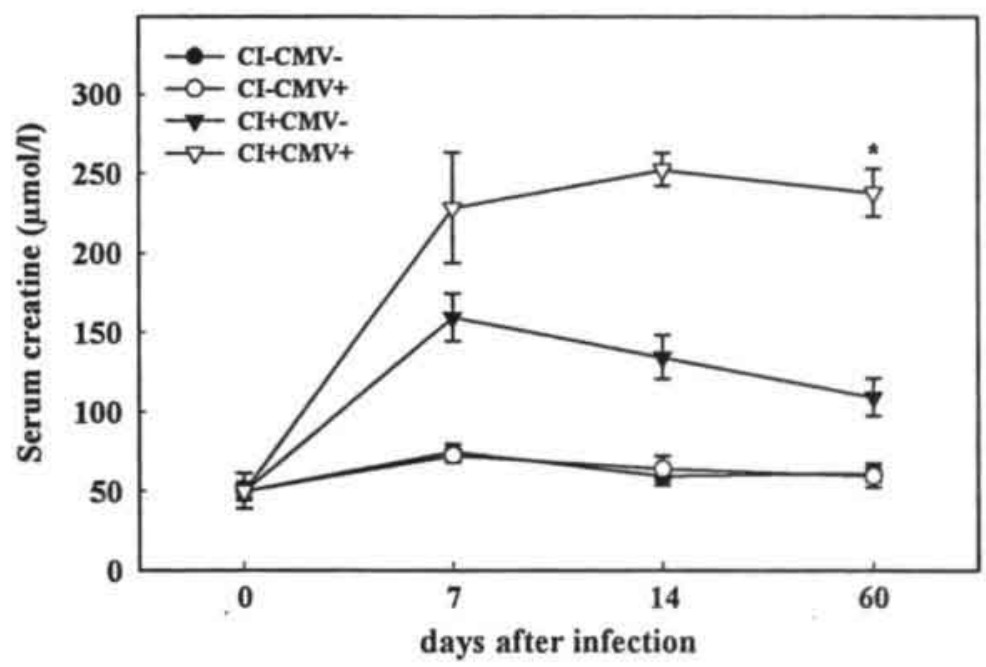

Fig. 1. Effect of $C M V$ infection and prolonged cold ischemia on levels of serum creatinine in renal graft recipients. Data are presented as mean \pm SEM. * $P<0.05$ compared to all other groups. 


\section{Function of renal allografts}

Figure 1 shows the effects of CMV infection, prolonged cold ischemia and their combination on the levels of serum creatinine. The creatinine levels in the non-ischemic groups (CI-CMV- and $\mathrm{CI}-\mathrm{CMV}+$ ) remained constantly low throughout the entire experimental period (60 days) compared to the normal (pre-operative) values. A moderate elevation of serum creatinine was observed in the recipients of renal allografts that were subjected to prolonged cold ischemia $(\mathrm{CI}+\mathrm{CMV}-)$. The $\mathrm{CMV}$ infected animals with ischemically injured renal grafts $(\mathrm{CI}+\mathrm{CMV}+)$ demonstrated over 3-fold higher values than the groups 1 and $2(\mathrm{P}<0.05)$.

\section{Morphological changes in allografts}

Effects of CMV infection and prolonged $\mathrm{CI}$ on the pathology scores of renal allografts 60 days after transplantation were shown in Table 1. When compared with the control group, CMV infection alone (CI-CMV+) caused marked vascular lesions, i.e. increased glomerular sclerosis and intimal proliferation in afferent and efferent glomerular arterioles. Prolonged cold ischemia alone (CI+CMV-) resulted in a significant augmentation of interstitial fibrosis, glomerular sclerosis and tubular atrophy, leading to a dramatic increase of the $\mathrm{CADI}$. The $\mathrm{CI}+\mathrm{CMV}+$ group exhibited significantly more interstitial fibrosis, glomerular sclerosis and tubular atrophy than the control (CI-CMV-) and $\mathrm{CMV}$ infected groups (CI-CMV+ and $\mathrm{CI}+\mathrm{CMV}+)$ and demonstrated significant enhancement of interstitial inflammation comparing to the prolonged cold ischemia group. As a result, the $\mathrm{CADI}$ of the $\mathrm{CI}+\mathrm{CMV}+$ group was increased approximately two-fold compared to the controls $(\mathrm{P}<0.05)$. The $\mathrm{CADI}$ scores of the $\mathrm{CI}+\mathrm{CMV}+$ group were also significantly higher than the scores of the $\mathrm{CI}-\mathrm{CMV}+$ and $\mathrm{CI}+\mathrm{CMV}$ - group.

\begin{tabular}{|c|c|c|c|c|}
\hline & $\mathrm{Cl}-\mathrm{CMV}$ - & $\mathrm{CI}-\mathrm{CMV}+$ & $\mathrm{Cl}+\mathrm{CMV}-$ & $\mathrm{CI}+\mathrm{CMV}+$ \\
\hline Interstitial inflammation & $1.7 " 0.2$ & $1.9 " 0.1$ & $1.7 " 0.1$ & $2.2 " 0.1^{\mathrm{c}}$ \\
\hline Interstitial fibrosis & 0.4 "0.2 & 0.4 " 0.1 & $1.8=0.1^{2, b}$ & $2.0^{n} 0.2^{2, b, c}$ \\
\hline Mesangial matrix increase & $1.5 " 0.1$ & $1.4 " 0.2$ & $1.3 " 0.1$ & $1.5 " 0.1$ \\
\hline Glomerular sclerosis & 0.1 "0.1 & $0.5{ }^{\prime \prime} 0.1^{*}$ & $1.0 " 0.1^{2, b}$ & $1.1^{\mathrm{n}} 0.1^{\mathrm{ab}}$ \\
\hline Intimal proliferation & $1.3 " 0.1$ & $1.9^{\prime \prime} 0.1^{2}$ & $1.3 " 0.2$ & $1.9 " 0.2^{2 e c}$ \\
\hline Tubular atrophy & $0.6 " 0.2$ & $0.5 " 0.1$ & $1.9^{n} 0.1^{a b}$ & $2.0 \mathrm{~m} 0.3^{\mathrm{ab}}$ \\
\hline CADI* & $5.6 " 0.5$ & $6.8 " 0.5$ & $8.9^{\prime \prime} 0.3^{2 . b}$ & $10.7^{" 0} 0.1^{2, b, c}$ \\
\hline
\end{tabular}

Table 1. The effects of CMV infection and prolonged cold ischemia on histological changes of renal allografts

\# represents chronic allograft damage index

a $P \leq 0.05$ compared to the $C I-C M V-$ group

$b_{P} \leq 0.05$ compared to the $\mathrm{Cl}-\mathrm{CMV}+$ group

${ }^{\circ} \mathrm{P} \leq 0.05$ compared to the $\mathrm{CI}+\mathrm{CMV}$ - group

\section{Infiltration patterns of inflammatory cells}

Lymphocytes, monocytes/macrophages, natural killer cells and B cells were observed in the renal allografts. The most prevalent infiltrating cell was the $\mathrm{CD} 4^{+}$cell, that was found predominantly 


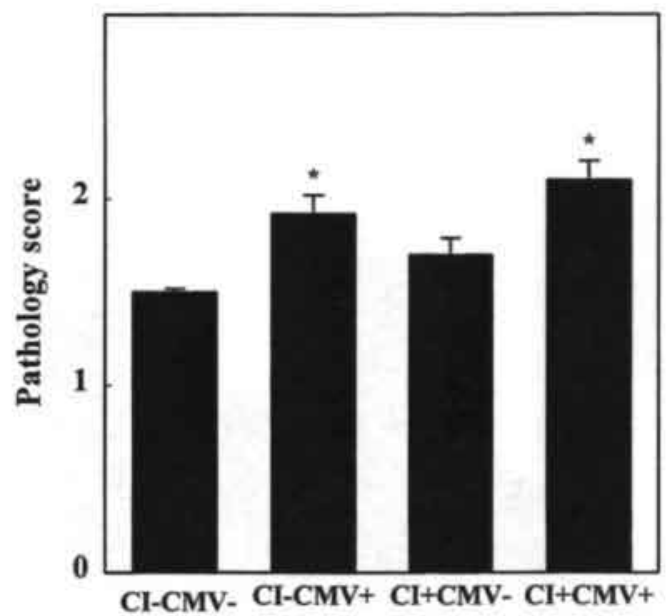

Fig. 2. Effect of CMV infection and prolonged cold ischemia on perivascular infiltration of CD4+ cells in renal allografts. Immunohistochemical staining and scoring techniques are described in Materials and Methods. Data are expressed as mean $\pm S E M$ * represents $P<0.05$ compared to the $C I$-CMV-group .

in perivascular areas. CMV infection increased the perivascular accumulation of $\mathrm{CD}^{*}$ cells on day 10 after transplantation compared to the controls (Figure 2), while prolonged cold ischemia alone did not influence the extravasation of $\mathrm{CD}^{+}$cells. Sixty days after transplantation, although the magnitude of perivascular invasion of $\mathrm{CD}^{+}$cells remained the same as on day 10 , there were no significant differences between the groups studied. Unlike the $\mathrm{CD}^{+}$cells, the perivascular accumulation of $\mathrm{CD}^{+}$cells was affected neither by CMV infection nor by prolonged cold ischemia.

$\mathrm{CMV}$ infection $(\mathrm{CI}-\mathrm{CMV}+$ and $\mathrm{CI}+\mathrm{CMV}+)$ significantly increased the interstitial accumulation of monocytes/macrophages (ED1+ cells) on day 10 after transplantation compared to the controls (Figure 3). This CMV-induced increase in interstitial ED1+ cells disappeared at day 60 (data not shown). Prolonged cold ischemia did not exhibit influence on the accumulation of ED1+ cells. Although there were relatively more infiltrating ED1+ cells in the perivascular regions than in the interstitial areas, no effect of CMV infection or prolonged cold ischemia on the perivascular infiltration was observed.

The intensity of perivascular and interstitial infiltration of natural killer cells at 10 days was increased significantly by prolonged cold ischemia and further exacerbated by the combination of $\mathrm{CMV}$ infection with prolonged cold ischemia $(\mathrm{CI}+\mathrm{CMV}+)$ compared to the controls (Figure 4). The differences between the groups were no longer detected at day 60 .

\section{Expression of MHC class II antigens}

Scores of MHC class II antigens in arteriolar endothelium at day 60 after transplantation is shown in Figure 5. $\mathrm{CMV}$ infection ( $\mathrm{CI}-\mathrm{CMV}+$ and $\mathrm{CI}+\mathrm{CMV}+$ ) significantly increased the expression 


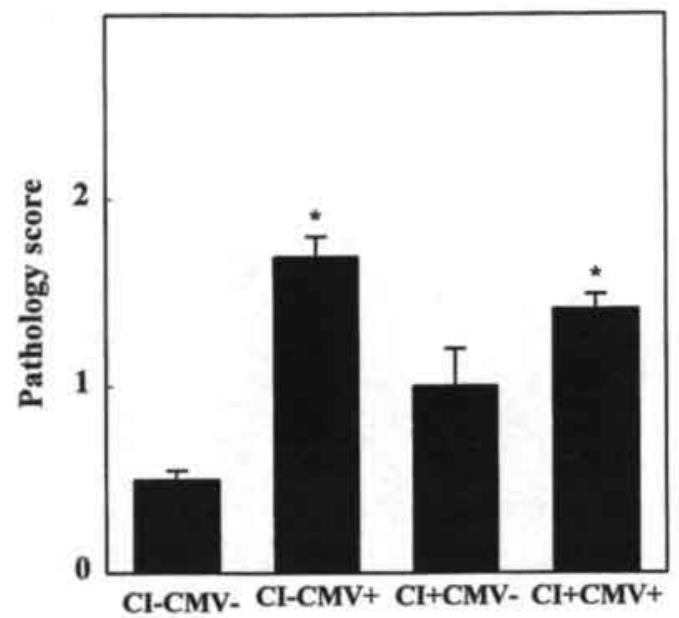

Fig. 3. Effect of CMV infection and prolonged cold ischemia on interstitial infiltration of EDI+ monocytes/macrophages in renal allografts 10 days after transplantation. Immunohistochemical staining and scoring techniques are described in Materials and Methods. Data are expressed as mean $\pm S E M$. * represents $P$ $<0.05$ compared to the $\mathrm{CI}-\mathrm{CMV}$ - group.

of MHC class II antigens. Interestingly, a down-regulated expression of the antigens was observed in the allografts with prolonged cold ischemia alone (CI+CMV-). There was no endothelial expression of MHC class II antigen in any experimental group at day 10 after transplantation.

\section{DISCUSSION}

The present study demonstrated that CMV infection and prolonged cold ischemia had additive effects on deterioration of the function of kidney allografts. However, these effects were not histologically synergistic, since CMV infection tended to induce vascular changes (intimal proliferation and glomerular sclerosis), while prolonged cold ischemia increased interstitial fibrosis, tubular atrophy and glomerular sclerosis. The increased transplant intimal proliferation or allograft arteriosclerosis by CMV infection has been found not only in kidney transplants, but also in cardiac, pulmonary and aortic allografts $(5,9,18)$, suggesting that the effect of CMV on the allograft vasculature is a general phenomenon. It has been well established that $\mathrm{T}$ cell mediated endothelialitis is the hallmark of vascular rejection (19) and that repeated episodes of acute rejection accelerate the development of chronic rejection (3). It is, therefore, postulated that the accelerated transplant arteriosclerosis in CMV-infected recipients may be a process mediated by $\mathrm{T}$ cells that have been activated specifically by the early CMV infection. This hypothesis is supported, at least partly, by the fact that the early infiltration of $\mathrm{CD}^{+}$cells and late influx of $\mathrm{CD}^{+}$cells were enhanced in the renal grafts of CMV-infected hosts. It is also possible that allograft endothelium harboring CMV has the potential to activate host $\mathrm{T}$ cells and that the consequent release of cytokines has the potential to raise surrounding endothelium to a fully 
activated, highly immunogenic state (20), which may promote the development of chronic rejection in allografts without active virus being present in the grafts as seen in this study (21).

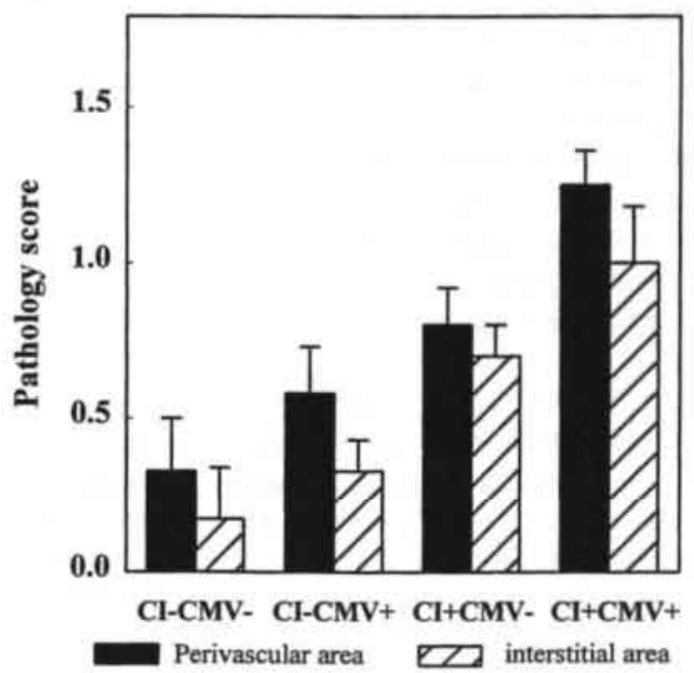

Fig. 4. Effect of CMV infection and prolonged cold ischemia on infiltration of natural killer cells in renal allografts 10 days after transplantation. Immunohistochemical staining and scoring techniques are described in Materials and Methods. Data are expressed as mean \pm SEM. represents $P<0.05$ compared to the CI-CMV-group; \# represents $P<0.05$ compared to the $\mathrm{Cl}-\mathrm{CMV}+$ group.

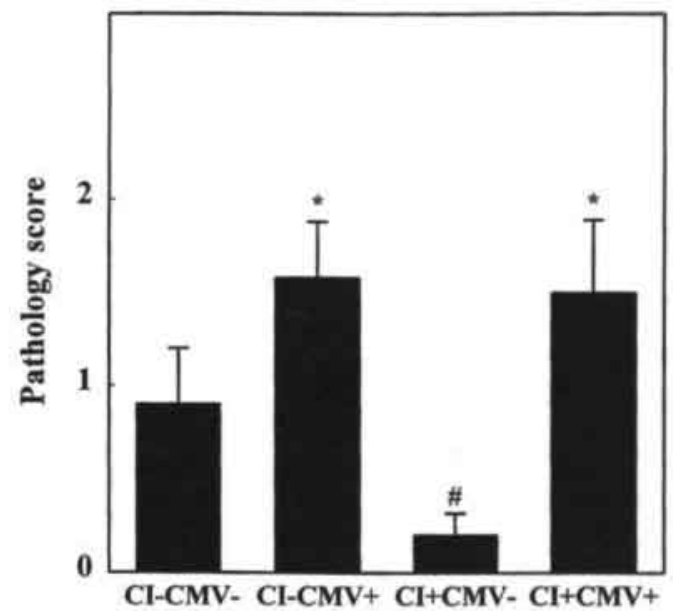

Fig. 5. Effect of CMV infection and prolonged cold ischemia on expression of MHC class II antigens in arteriolar endothelial cells of renal allografts 60 days after transplantation. Immunohistochemical staining and scoring techniques are described in Materials and Methods. Data are expressed as mean \pm SEM. * represents $P<0.05$ compared to the $\mathrm{Cl}-\mathrm{CMV}$ - group; \# represents $\mathrm{P}<0.05$ compared to all other groups. 


\section{Chapter 7}

Prolonged cold ischemia led to interstitial fibrosis, glomerular sclerosis and tubular atrophy, the histological alterations typically seen in biopsies of renal allografts undergoing chronic rejection $(2,3)$. It is known that the prolonged ischemia may cause the necrosis of tubular cells due to hypoxia and reperfusion injury early after transplantation (22). This may cause loss of functional mass, a factor held responsible for the development of chronic rejection (3). Endothelium represents the initial and perpetual interface between the host immune system and allograft tissue (23), and endothelial injury plays an important role in the development of arteriosclerosis (20). Endothelial injury caused by prolonged ischemia and subsequent reperfusion may result in upregulation of adhesion molecules. This may, in turn, activate circulating leukocytes to release cytokines, thereby initiating the cytokine-adhesion molecule cascade $(8,20,21)$ and leading to the influx of leukocytes and tissue destruction.

The upregulated expression of MHC class II antigens is one of the factors known to be important in the development of allograft rejection $(6,24,25)$. Moreover, ischemia/reperfusion injury was recently shown to involve components of an inflammatory reaction, which may increase graft immunogenicity via events such as upregulation of $\mathrm{MHC}$ as well as of the cytokine-adhesion molecule cascade, followed by subsequent extravasation (10). In the present study, CMV infection alone or in combination with prolonged cold ischemia caused a significant upregulation of MHC class II antigen expression on endothelial cells, a phenomenon previously found in in vitro models $(24,26)$. The enhanced expression of MHC class II may enable a direct presentation of foreign antigens to alloreactive $\mathrm{T}$ cells, and the local macrophages that were increased, as noted in the study, may process donor alloantigens for indirect $\mathrm{T}$ and $\mathrm{B}$ cell activation, leading to further recruitment of $\mathrm{CD}^{+}$and $\mathrm{CD}^{+}$cells and macrophages into the graft, which in turn may induce local cytokine and growth factor production and ultimately graft deterioration.

Prolonged cold ischemia increased and CMV infection exacerbated the influx of natural killer cells. The exact role of natural killer cells in the pathogenesis of chronic rejection is not clear, but it is known that they have cytotoxic capacity and are able to upregulate MHC class II expression via interferon gamma.

In summary, the results of the present study suggests that special attention should be paid to the CMV-infected recipient receiving an ischemically injured kidney graft, since an accelerated development of chronic rejection may occur in this situation. CMV infection accelerates the renal graft deterioration probably through pathways different from ischemia-reperfusion injury. Among others, the increased risk of chronic rejection in kidney allografts may be associated with an upregulated expression of MHC class II antigens by the viral infection and ischemic injury.

\section{REFERENCES}

1. Cecka JM (1994) Outcome statistics of renal transplants with an emphasis on long-term survival. Clin Transplantation 8:324-327

2. Almond PS, Matas A, Gillingham K, et al (1993) Risk factors for chronic rejection in renal allograft recipients. Transplantation 55:752-757

3. Tullius SG, Tilney NL (1995) Both alloantigen-dependent and independent factors influence chronic allograft rejection. Transplantation 59:313-318 
4. Gao SZ, Alderman EL, Schroeder JS, Silverman JF, Hunt SA (1988) Accelerates coronary vascular disease in the heart transplant patient: coronary arteriographic findings. J Am Coll Cardiol 12:334-340

5. Grattan MT, Moreno-Cabral CE, Starnes VA, Oyer PE, Stinson EB, Shumway NE (1989) Cytomegalovirus infection is associated with cardiac allograft rejection and atherosclerosis. JAMA 261:3561-3566

6. Häyry P, Mennander A, Răisänen-Sokolowski A, Ustinov J, Lemström K, Aho P, Yilmaz S, Lautenschlager I, Paavonen T (1993) Pathophysiology of vascular wall changes in chronic allograft rejection. Transplantation Reviews 7:1-5

7. Robin RH (1990) Impact of cytomegalovirus infection on organ transplant recipients. Rev Infect Dis 12(suppl 7):S754-S766

8. Hayry P, Lemstrom K, von Willebrand E, Tikkanen J, Koskinen P (1998) CMV infection and allograft rejection. Transplant Proc 30:916-917

9. Lemström KB, Bruning JH, Bruggeman CA, Lautenschlager IT, Hăyry PJ (1993) Cytomegalovirus infection enhances smooth muscle cell proliferation and intimal thickening of rat aortic allografts. J Clin Invest 92:549558

10. Land W (1994) The potential impact of the reperfusion injury on acute and chronic rejection events following organ transplantation. Transplant Proc 26:3169-3171

11. Rehbinder C, Baneux P, Forbes D, Van Herck H, Nicklas W, Rugaya Z, Winkler G (1996) FELASA recommendations for the health monitoring of mouse, rat, hamster, gerbil, guineapig and rabbit experimental units. Lab Anim 30: 193-208

12. Yin M, Booster MH, vd Bogaard AEJM, Kootstra G (1994) A simple technique to harvest two kidneys from one donor rat for transplantation. Laboratory Animals 28:387-390

13. Hancock WW, Whitley WD, Tullius SG, Wasowska B, Baldwin WM 3d, Tilney NL (1993) Cytokines, adhesion molecules and the pathogenesis of chronic rejection of rat renal allografts. Transplantation 56:643650

14. Bruggeman CA, Meijer H, Dormans PHJ, Debie WMH, Grauls GELM, and van Boven CPA (1982) Isolation of a cytomegalovirus-like agent from wild rats. Arch Virol 73: 231-241

15. Bruggeman CA, Meijer H, Bosman F, van Boven CPA (1985) Biology of rat cytomegalovirus infection. Intervirology 24: 1-9

16. Bruning JH, Debie WHM, Dormans PHJ, Meijer H, Bruggeman CA (1987) The development and characterisation of monoclonal antibodies against rat cytomegalovirus induced antigens. Arch Virol 94:55-70

17. Isoniemi HM, Krogerus L, von Willebrandt E, Taskinen E, Ahonen J, and Hayry P (1992) Histopathological findings in well-functioning, long-term renal allografts. Kidney Int 41:155-160

18. Steinhoff G, You X-M, Steinmuller C Brauer D, Lohmann-Matthes M-L, Bruggeman CA, Haverich A (1996) Enhancement of cytomegalovinus infection and acute rejection after allogeneic lung transplantation in the rat. Transplantation 61:1250-1260 20.

19. Salomon RN, Hughes CC, Schoen FJ, Payne DD, Pober JS, Libby P (1991) Human coronary transplantationassociated arteriosclerosis: Evidence for a chronic immune reaction to activated graft endothelial cells. Am J Pathol 138:791-798

20. Ross R (1993) The pathogenesis of atherosclerosis: a perspective for the 1990s. Nature 362:801-809

21. Waldman WJ and Knight DA (1996) Cytokine-mediated induction of endothelial adhesion molecule and histocompatibility leukocyte antigen expression by cytomegalovirus-activated T cells. Am J Pathol 148:105119

22. Southard JH, Marsh DC, McAnulty JF, Belzer FO (1987) The importance of $\mathrm{O}_{2}$-derived free radical injury in organ preservation and transplantation. Transplant Proc 19:1380-1381

23. Sedmak DD, Orosz CG (1991) The role of vascular endothelial cells in transplantation. Arch Pathol Lab Med 115:260-265

24. Ustinov JA, Loginov RJ, Bruggeman CA, van der Meide PH, Haryry P, and Lautenschlager IT (1993) Cytomegalovirus induces class II expression in rat heart endothelial cells. J Heart Lung Transpl 12:644-651

25. von Willebrand E, Petterson E, Ahonen J, Hăyry P (1986) CMV infection, class II antigen expression, and human kidney allograft rejection. Transplantation 42:364-367

26. Ustinov JA, Loginov RJ, Mattila PM, Nieminen VK, Suni J, Hăyry PA, and Lautenschlager IT (1991) Cytomegalovirus infection of human kidney cells in vitro. Kidney International 40:954-960 



\section{SUMMARY AND GENERAL DISCUSSION}




\section{SUMMARY AND GENERAL DISCUSSION}

Growing knowledge of transplant immunology and introduction of new immunosuppressive agents have dramatically improved the early results of organ transplantation. However, chronic rejection, or TAA, is still a major obstacle to long-term survival of transplanted organs. Although the exact mechanisms responsible for the initiation and progression of TAA are not completely understood, it has been postulated that TAA may be induced or accelerated by CMV infection. In this thesis, a series of experiments were designed to further characterize the role of CMV infection in the development of chronic rejection, using rat aortic and renal transplantation models.

In the first study of the thesis (chapter 3), a correlation between the intensity of CMV infection and the amount of perivasculitis, one of the pathological characteristics of TAA, was investigated in rat aortic allografts. For this purpose, recipients were inoculated with either active RCMV (living virus) or inactivated RCMV (dead virus) and were immunosuppressed by sublethal challenge of total body irradiation to enhance the generalized CMV infection in hosts, mimicking the clinical situation of immune-compromised transplant recipients with CMV infection. The subsequent general (transplant recipient) and local (transplanted organ or tissue) CMV infection in rats was evaluated by plaque titration assay for infectious virus and immunohistochemical staining for viral antigens. As expected, the amount of virus replication in the host was related to the dosages of total body irradiation, i.e. the viral replication was enhanced in animals receiving $5 \mathrm{~Gy}$ of total body irradiation than those given none or $3 \mathrm{~Gy}$ of total body irradiation. Although the number of inflammatory cells accumulating in the graft perivascular area was decreased after total body irradiation, CMV infection caused enhanced perivasculitis in rats that received $5 \mathrm{~Gy}$ of total body irradiation compared to the non-infected animals. Immunohistochemical study demonstrated that the CMV-induced effect was characterized predominantly by an increased $\mathrm{T}$ lymphocyte infiltration, including both $\mathrm{CD}^{+}$and $\mathrm{CD} 8^{+} \mathrm{T}$ cells. In summary, (1) higher degree total body irradiation ( $5 \mathrm{~Gy}$ ) enhanced the replication of RCMV, leading to CMV infection in almost all the organs of the animals; (2) the magnitude of inflammatory response (perivasculitis) in aortic allografts correlated with the amount of infectious virus in the hosts; (3) the increased perivasculitis related more to the enhanced systemic CMV infection in the host by strong immunosuppression than to the early immunosuppression per se.

Since no infectious virus nor viral antigens were detectable in the vessel wall we propose that or the level of virus and viral antigens is too low for the detection techniques used in this study or the virus remains in a latent, yet undetectable state in the vessel wall. Another mechanism involved in the persistent inflammation observed in this study is that the effect is probably the result of presence of virus in the host leading to stimulation of the alloreaction. Since we know from human studies that CMV is able to persist in the vessel wall, especially in the smooth muscle cell layer, we speculate that the same occurs in the ratmodel and that the virus is present at very low levels in a non infectious state in the aorta and that its presence is responsible for the effects observed in this study. 
Endothelial cells of allografts, which can be injured during preservation and/or early reperfusion, are the primary targets of host immune responses. The injured endothelial cells might release various growth factors, which in turn cause migration of smooth muscle cells into the intima and replication of smooth muscle cells in the neointima, thus leading to intimal thickening, a major feature of TAA. Moreover, it has been postulated that the immune inflammatory cells and factors they produce may also play an important role in the development of intimal proliferation. Therefore, in the second study of the thesis (chapter 4), the role of early endothelial cells injury in the progression of TAA was investigated with allogeneic (BN to Lewis combination, across both MHC class I and II barriers) and syngeneic (Lewis to Lewis) aortic transplantation model. In the longitudinal sections of aortic allografts, an endothelial denudation was observed as early as day 2 in both allografts and isografts. The anastomosis areas of aortic grafts exhibited more profound endothelial lesion than the mid-segments of grafts. There was more severe endothelial cells denudation in allografts compared to syngeneic grafts. Regeneration of endothelial cells in allografts was observed at day 7 , but was not completed until day 28 . In syngeneic grafts, however, the regeneration was quicker. Likewise, neointima formation occurred earlier at the anastomosis area than the middle sections of grafts and was only observed in the allografts. These tendency existed until day 28 . Unlike isografts, an infiltration of inflammatory cells (mainly monocytes and lymphocytes) in the adventitia of allografts (perivasculitis) was observed at day 7. The inflammation reached the peak at day 28 , declined slowly thereafter, but persisted at relative lower levels until day 60 . These results provided strong evidence that the initial endothelial injury is related to the accelerated development of the alloantigen-dependent arteriosclerotic lesions.

Effects of $\mathrm{CMV}$ infection on the components of perivascular infiltration of inflammatory cells and extents of neointima formation in aortic allografts were described in Chapter $\mathbf{5}$ of the thesis. As the above experiments, the immunosuppressed ( $5 \mathrm{~Gy}$ total body irradiation) aortic recipients were inoculated with RCMV or left uninfected. Compared with the minimum pathological changes in syngeneic grafts, an increased perivascular influx of inflammatory cells in allografts, which peaked at day 28 , was observed. Although there was only a slightly enhanced inflammation in the CMV-infected allografts than the non-infected group, a significant difference in number of infiltrating $T$ cells was observed in the infected allografts at day 28. Immunohistochemical study demonstrated that CMV infection caused increased influx of both $\mathrm{CD}^{+}$and $\mathrm{CD}^{+} \mathrm{T}$ lymphocytes and led to activation of these cells, as indicated by higher expression of interleukin- 2 receptors. This enhanced $\mathrm{T}$ cell influx was related to the presence of active replicating virus in the host. Further, a clear tendency for increased intimal thickening was found in the infected allografts. At later stage (day 90), CMV infection also resulted in augmented expression of MHC class II positive cells in allografts. Perivascular infiltration of monocytes and macrophages and expression of intercellular adhesion molecule-1 and lymphocyte function-associated antigen-1 were not influenced by the infection. It is, therefore, concluded that active $\mathrm{CMV}$ infection may cause increased perivascular influx of leucocytes resulting intimal thickening in the aortic allografts.

Since the above CMV-enhanced perivasculitis appeared to be a mainly $\mathrm{T}$ cell mediated process, in which $\mathrm{MHC}$ antigens played an important role, the effects of $\mathrm{CMV}$ infection on chronic 


\section{Chapter 8}

rejection seems to be related to its action on immune modulation. The next question raised in chapter 6 of the thesis was what role of MHC antigens (class I or II antigens) play in the CMVenhanced TAA, or in another words, which kind of MHC mismatched allografts was influenced more by CMV infection? Towards this end, we transplanted aortas across either MHC class I or class II different barriers in absence or presence of CMV infection. It was found that the exchange of allografts between rat strains that displayed histocompatibility differences in either class I or II led to neointima formation. However, CMV infection significantly accelerated this process more in the MHC class I different combination than class II disparity. Interestingly, this increased neointima formation in MHC class I mismatched combination was associated with the early (day 7) increased infiltration of monocytes/macrophages in the perivascular area of allografts. It seems that no direct correlation exists between the intensity of perivascular infiltration and the neointima formation, since in MHC class II-mismatched combination CMV infection upregulated $\mathrm{T}$ cell influx at day 28 , but intimal thickening was not significantly stimulated. The findings of this study suggest that CMV infection stimulates the effect of MHC class I mismatching.

Although the same observations are not described for other virus, there is a lot of evidence that similar effects are generated by other viral infections. For example infections with lymphocytic choriomeningitis virus lead to the generation of alloreactive $T$ lymphocytes. These alloreactive cells lyse allogeneic but not syngeneic cells. There are also indications that they are directed especially against allogeneic MHC class I antigens. Also in mice infected with CMV high levels of alloreactive T cells were found. MHC class I antigen serves as a target for these cells. In a setting with class II disparity no virus-induced effect was observed. In the mice it was shown that CMV infection enhances the severity of graft-versus-host-disease across a class I disparity. Taken together all these results indicate that virus and especially CMV infection stimulates the alloreaction especially when MHC class I disparity between donor and recipient are present. Wether presence of homologs of the virus and MHC class I are importance for this allostimulation is not known. This should be further analysed probably using deletion mutants of the virus.

Prior to transplantation, organs from cadaveric donors are unavoidably subjected to cold ischemia during organ procurement, transportation and preservation awaiting for tissue typing. Ischemia and the subsequent reperfusion may cause grafts injury, which has also been implicated as a risk factor for chronic rejection. This leads to a question whether CMV infection and prolonged ischemia $(24 \mathrm{~h})$ act synergistically on the progression of chronic rejection. To elucidate this question, a rat renal transplantation model was used in the chapter 7. Lewis recipients of BN renal allografts treated shortly with cyclosporin $A(15 \mathrm{mg} / \mathrm{kg})$ were killed on days 10 or 60 . The data showed that CMV infection alone increased inflammatory responses, neointima formation and glomerular sclerosis in renal allografts. Proceeding prolonged cold ischemia resulted in even profound injury and inflammation in the renal grafts of CMV infected recipients. Immunohistochemical staining of grafts removed on day 10 showed an increased perivascular infiltration of monocytes/macrophages and interstitial influx of CD8 ${ }^{+} \mathrm{T}$ cells in the $\mathrm{CMV}$ infected allografts. Long cold ischemia alone, however, led to enhanced perivascular and interstitial influx of natural killer cells. In grafts with both long cold ischemia and CMV infection, a higher intensity of infiltrating $\mathrm{CD}^{+}$and $\mathrm{CD} 8^{+} \mathrm{T}$ cells, natural killer cells and monocytes/macrophages 
was observed. At day 60, CMV infection resulted in enhanced expression of MHC class IIantigens on endothelium in the allograft. The result suggest a synergistic effect of prolonged cold ischemia and $\mathrm{CMV}$ infection in the development of chronic rejection.

TAA can be considered as the result of direct immunological injury to the vessel wall. It has been proposed that attachement of lymphocytes to the allogeneic endothelium and subsequent endothelial damage create an "activation" state than trigger intimal proliferation. Infections with CMV accelerates this process.

CMV is known for its potential to stimulate endothelial cells. Its effects include the induction of proliferation and also the upregulation of adhesion molecules, MHC class I and MHC class II. The expression of these molecules is important for allograft rejection. CMV is also able to stimulate the production of important compounds such as chemoattractants for leucoccytes, IL-1, IL-6, IFN- $\gamma$ and TNF. CMV not only activates endothelial cells but also activates monocytes/macrophages. These cells are important producers of growth factors. Most likely the effects of CMV infection on TAA are due by a combination of an increased infiltration of leucocytes and activation of endothelial cells and monocytes/macrophages.

Although the etiology of TAA is presumed to be alloantigen-dependent and immunologically derived also is clear that nonimmunologic factors such as ischemic have important roles in the induction and progression of the disease. The central hypothesis is that some form of damage of the endothelium of the graft results in dysfunction of the endothelium. The damage can as shown in our study be induced by the alloreaction, by $\mathrm{CMV}$ infection and by ischemia. The role of CMV in this process is dependent of active virus in the host (i.e. the rat) but is not dependent of active virus infection of the endothelial cells i.e. replication of CMV in endothelial cells. Although the activation of TAA by CMV is not completely understood two possible mechanisms could be involved:

- the first mechanism is that entry of the virus in cells leads into a activation of these cells resulting in (enhanced) expression of adhesion molecules, cytokines and chemokines leading to (enhanced) interaction with $\mathrm{T}$ lymphocytes and monocytes/macrophages resulting in production of active compounds such as TNF and $\mathrm{IL}-1$ and growth factors.

- The second mechanism is that CMV infection of the host leads to a stimulation of the immunereaction in general and of the alloreaction in particular.

- The finding that CMV infection failed to induce TAA in syngeneic grafts provides evidence for the hypothesis that TAA is an immunologic event and that the alloreaction is necessary for its occurance.

From data of atherosclerosis and restenosis experiments obtained in our and other laboratories together with the data in this thesis, it can be concluded that CMV infection of the host is involved directly or indirectly in upregulation of chronic inflammatory responses in the allograft and in proliferation of smooth muscle cells leading into (enhanced) neointima formation (Fig. 1). These effects are induced by very low, even undetectable levels of active virus in the host. Induction of "active" compounds such as cytokines an growth factors are involved in the indirect effects while interaction of viral gene products with cellular gene products (such as p53) are probably involved in the direct effects. 


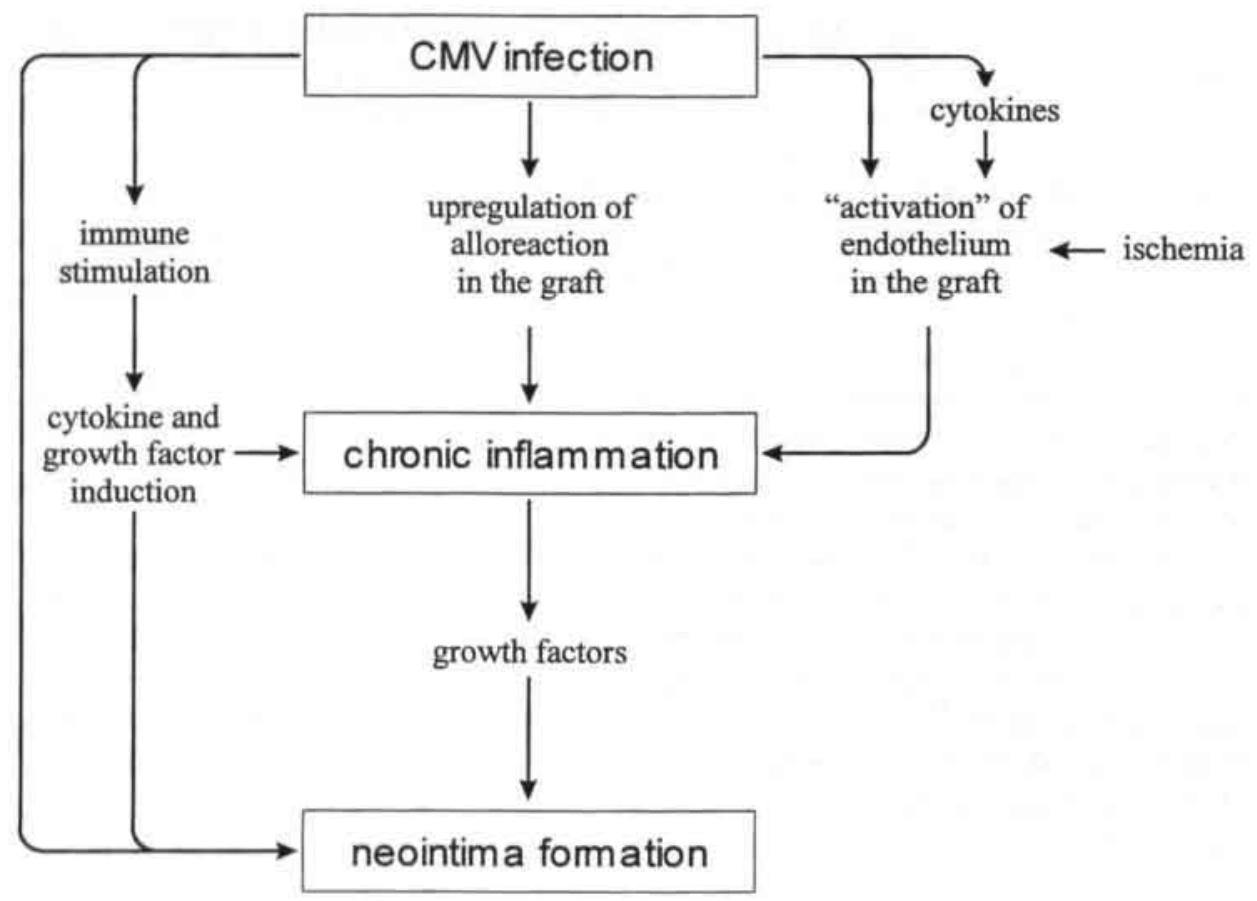

Fig. 1. Direct and indirect effects of CMV infection on chronic inflammation and neointima formation. 


\section{SAMENVATTING}

Alhoewel de resultaten van orgaantransplantaties -in het bijzonder van niertransplantaties- over het algemeen bijzonder goed zijn waardoor de overlevingskansen van patiënten die een getransplanteerd orgaan ontvangen hebben sterk toegenomen zijn, komen er op langere termijn veelvuldig complicaties voor. Deze langer(e) termijneffecten worden ook wel chronische afstoting genoemd. Deze worden gekenmerkt door een chronische ontsteking in het getransplanteerde orgaan welke op termijn het "normale" functioneren van het orgaan verstoort. Een van de belangrijkste kenmerken van dit proces is de voortdurende (persisterende) ontstekingsreactie, rondom de vaten van het getransplanteerde orgaan en een verdikking van de vaatwand (neointimavorming) waardoor de opening (lumen) van het vat verkleint en op termijn zelfs helemaal afgesloten wordt. Dit proces wordt ook wel transplantatie-geassocieerde arteriosclerose genoemd. Niet alle oorzaken van het optreden van dit arteriosclerose-proces zijn bekend. Van een aantal factoren weten we inmiddels wel dat ze een rol spelen in het optreden van deze transplantatie-geassocieerde arteriosclerose. Eén ervan is de afstotingsreactie die optreedt tengevolge van de verschillen in weefselantigenen, ook wel transplantatie-antigenen genoemd, op cellen van de donor van het orgaan en van de ontvanger van het orgaan.

Daarnaast zijn nog andere factoren bekend die een rol spelen, tot deze behoren wellicht ook de infecties met het cytomegalovirus (CMV).

De bijdrage van infecties met CMV aan de chronische afstoting na orgaantransplantatie werden voor het eerst aangetoond op het eind van de jaren tachtig in de Verenigde Staten van Amerika door Grattan en medewerkers. Sindsdien is dit, zij het met wisselend succes, aangetoond door diverse andere onderzoekers. Om de mogelijke bijdrage van CMV-infecties aan het arteriosclerose proces nader uit te zoeken, maar nu in "goed gedefinieerde" omstandigheden, werd het onderzoek dat in dit proefschrift beschreven wordt, ondernomen.

In dit proefschrift werd het onderzoek naar de bijdrage van CMV infecties aan het ontstaan van transplantatie-geassocieerde arteriosclerose onderzocht door gebruik te maken van diermodellen. Het rattenmodel is voor transplantatie onderzoek een frequent gebruikt diermodel dat door de beschikbaarheid van inteelt rattenstammen ook geschikt is om de afstotingsreactie nader te bestuderen. Door de beschikbaarheid van ratten-CMV (RCMV), dat sterkte verwantschap vertoont met het humane CMV, is ook virologisch onderzoek in een dergelijk diermodel mogelijk. Voor het transplantatie-onderzoek werden er twee modellen gebruikt: het eerste is het aortatransplantatiemodel. Dit model is een relatief ongecompliceerd transplantatiemodel dat eenvoudig uitvoerbaar is en het grote voordeel heeft dat er geen immuunsuppressie noodzakelijk is om het transplantaat in de ontvangerrat te laten overleven. Het tweede model is het niertransplantatiemodel dat eveneens uitvoerbaar is in ratten en dat sterke gelijkenis vertoont met de situatie in de mens. Het model is complexer van aard maar biedt het voordeel dat het sterke gelijkenis vertoont met de in vivo situatie bij de mens.

In het eerste deel van het onderzoek (hoofdstuk 3) is de bijdrage van een CMV-infectie aan het ontstaan en de ontwikkeling van transplantatie-geassocieerde arteriosclerose onderzocht.

$\mathrm{Er}$ is voornamelijk aandacht besteed aan het optreden van de ontsteking die in de perivasculaire zone van het getransplanteerde vat ontstaat. Om dit te onderzoeken is gebruik gemaakt van twee 


\section{Chapter 8}

veelvuldig in Maastricht gebruikte en in de Centrale Dienst voor Proefdier- voorzieningen gefokte rattenstammen: de Bruine Noorse rat $(\mathrm{BN})$ en de Lewis rat. De dieren werden geïnjecteerd met RCMV dat afkomstig was van speekselklieren van acuut geïnfecteerde dieren. Als controle werd geïnactiveerd virus gebruikt.

CMV infecties worden gekenmerkt door een relatief onschuldig (subklinisch) infectieverloop bij de normaal gezonde gastheer d.w.z. bij de gastheer die een "normaal" functionerend immuunsysteem heeft. Wanneer echter de gastheer een verminderde weerstand heeft zoals dit het geval is, door toediening van immuunsuppressieve middelen hetgeen in de regel het geval is bij orgaantransplantaties, dan verloopt de CMV infectie veel ernstiger en treedt er uitgebreide CMV replicatie op in vele organen. De mate van de immuunsuppressie bepaalt grotendeels de ernst van de infectie. Om dit te bestuderen zijn daarom ook in dit onderzoek diverse doseringen van immuunsuppressie meegenomen.

De vorm van immuunsuppressie waarvoor in deze studie gekozen is, is de totale lichaamsbestraling. De doseringen die gebruikt werden waren: 3 Gray en 5 Gray. Daarnaast werden er niet-bestraalde dieren meegenomen. De dieren werden telkens met RCMV geïnfecteerd door middel van een intraperitoneale injectie met $10^{5}$ plaque vormende eenheden virus op de dag van de transplantatie. De ratten werden geofferd op dag 7 en 28 na transplantatie en de getransplanteerde aorta werd onderzocht.

Naast de allogene aortatransplantaties (van BN naar Lewis ratten) werden er ook syngene controles (BN-BN combinaties) meegenomen.

De aorta's werden onderzocht op aanwezigheid van virus en op aanwezigheid van morfologische veranderingen in de vaatwand. In het bijzonder ontstekingsinfiltraten werden aangekleurd. Dit gebeurde door immunoperoxidase kleuringen van paraffine coupes met behulp van specifieke monoclonale antistoffen gericht tegen antigenen op bepaalde cellen (lymfocyten en macrofagen). Zoals verwacht, was de hoeveelheid virus en virus geïnfecteerde cellen afhankelijk van de mate van immuunsuppressie. In dieren die de hoogste dosis immuunsuppressie gekregen hadden (5 Gray) was de infectie ernstiger dan in de dieren die een mildere vorm of geen immuunsuppressie gekregen hadden. Alhoewel de ontsteking in de perivasculaire ruimte in de vroege fase (dag 3) was afgenomen na de bestraling, was het effect van de CMV infectie toch duidelijk zichtbaar en dan in het bijzonder op een later tijdstip (dag 28). Het aantal T-lymfocyten was in geïnfecteerde dieren die 5 Gray lichaamsbestraling gekregen hadden, significant hoger dan in de niet-bestraalde dieren. In de dieren die een mildere vorm van immuunsuppressie gekregen hadden -ofwel geen immuunsuppressie- werd er geen significant verschil gevonden.

Verder onderzoek naar het soort T-lymfocyt dat aanwezig was in de perivasculaire ruimte toonde aan dat de stijging zowel de $\mathrm{CD}_{4}{ }^{+} \mathrm{T}$-cellen als de $\mathrm{CD}_{8}$ T-cellen betrof. Wat de influx van de monocyten/macrofagen betreft: ook bij deze cellen werd op dag 7 na bestraling een daling in de influx van cellen in de adventitia vastgesteld, die op dag 28 tenietgedaan werd. Bij deze cellen echter werd er geen significant verschil gevonden in de mate van influx van cellen in de adventitia tussen de geïnfecteerde en de niet-geïnfecteerde dieren.

Deze experimenten laten dus zien dat na een allogene aortatransplantatie er een ontstekingsreactie plaats vindt. Deze bestaat voornamelijk uit T-lymfocyten en uit macrofagen. Infecties met $\mathrm{CMV}$ leiden tot een toename in de influx doch voornamelijk van T-lymfocyten. Het effect van de infectie op de influx van monocyten/macrofagen is eerder beperkt. Wanneer de ontvangers immuunsuppressie ondergaan hadden was het virus-effect toegenomen. Een verklaring hiervoor 
ligt waarschijnlijk in de toename in virusreplicatie tengevolge van de immuunsuppressie waardoor de virus geïnduceerde pathologie, in dit geval de perivasculaire ontsteking, toeneemt. Het effect van het virus op de ontsteking in de adventitia werd niet gevonden bij de syngene getransplanteerde aorta's en ook niet wanneer geïnactiveerd virus werd toegediend. Dit wijst erop dat actieve replicatie van het virus in de gastheer noodzakelijk is maar ook dat er een verschil tussen donor en ontvanger aanwezig moet zijn (allogene barrière) om een viruseffect te kunnen waarnemen. De hypothese is dan ook, dat het hier geen rechtstreeks virus effect betreft, maar eerder een onrechtstreeks effect van het virus op de afweerreactie op het transplantaat en dat dit leidt tot versterkte ontsteking. Het virus versterkt de alloreactie en is derhalve immuunmodulerend, in dit geval immuunstimulerend actief.

De binnenkant van de vaten is bekleed met endotheelcellen. Deze cellen zijn van groot belang in een aantal vitale processen zoals stolling en bloeddruk en beschermen de onderliggende weefsels en cellen tegen "vreemde indringers" zoals onder andere virussen. Beschadiging van het endotheel leidt tot "activatie" van deze cellen waardoor er adhesiemoleculen op deze cellen tot expressie komen, leidend tot verhoogde adherentie van leucocyten aan het endotheel. Ook vindt er een verhoogde productie van "immuunactieve" stoffen plaats zoals onder andere interleukines en chemotactische stoffen zoals bijvoorbeeld interleukine-8 dat een chemo-attractant is voor de polymorfonucleaire cellen. Ook groeifactoren kunnen ten gevolge van schade van het endotheel geïnduceerd worden. Activatie van het endotheel kan daarnaast ook gebeuren ten gevolge van infecties zoals met CMV, maar ook bij vele andere processen, zoals bijvoorbeeld ischemie. Om het effect van schade aan het endotheel op transplantatie-geassocieerde arteriosclerose te bestuderen is onderzoek verricht in het aortatransplantatiemodel (hoofdstuk 4). In dit model werd het effect van de schade van het endotheel die in de eerste dagen na de transplantatie optreedt onderzocht op ten eerste het ontstaan van de perivasculaire ontsteking en de tweede op neointimavorming. Om dit te analyseren werden er van de getransplanteerde vaten dwars- en lengte-doorsneden gemaakt en werd op diverse tijdstippen na transplantatie de neointimavorming gemeten. De influx van ontstekingscellen werd geanalyseerd door gebruik te maken van de immunoperoxidase kleuring met monoclonale antistoffen gericht tegen (oppervlakte) antigenen op de diverse ontstekingscellen.

In dit onderzoek werd wederom de combinatie BN-Lewis ratten gebruikt als allogeen transplantatiemodel. Als controles werden er syngene (Lew-Lew) transplantaties gebruikt. Sterke endotheelschade was voornamelijk aanwezig op de anastomose-plaatsen, terwijl dit veel minder het geval was in het midden van het getransplanteerde vat. Regeneratie van het endotheel werd waargenomen vanaf dag 7 maar was nog niet volledig hersteld op dag 28. De vorming van een neointima in de allogene getransplanteerde vaten was het eerst op de plaats van de anastomose terwijl dit veel langzamer optrad in het midden van het vat. Op dag 60 na transplantatie was de neointima nagenoeg overal even sterk aanwezig d.w.z. over de hele lengte van het vat. In de syngene vaten vond er veel minder neointimavorming plaats en was deze voornamelijk aanwezig op de anastomose-plaatsen. Ook wat betreft de ontstekingsreactie in de adventitia was er duidelijk een verschil waar te nemen tussen de allogene vaten en de syngene vaten. In deze laatste was de ontsteking minder sterk aanwezig dan in de allogene vaten. Ook was de perivasculaire ontsteking veel langer aanwezig in de allogene vaten dan in de syngene vaten. Dit 


\section{Chapter 8}

toont aan dat verschillen tussen donor en ontvanger van groot belang zijn voor het optreden van een persisterende ontsteking in de getransplanteerde aorta. Ook voor de vorming van een neointima is het verschil tussen donor en ontvanger voor wat betreft weefselantigenen, van groot belang. Daarnaast levert beschadiging van het endotheel eveneens een bijdrage aan het optreden van de ontstekingsreactie in de adventitia. Dit effect is echter voornamelijk aanwezig in de acute fase (eerste dagen na transplantatie), maar is op zichzelf niet voldoende om te leiden tot langdurige ontsteking. CMV heeft een effect op de ontstekingsreactie rondom deze allogene vaten. Het effect van de infectie op de ontsteking is voornamelijk toe te schrijven aan een toename in het aantal (geactiveerde) T-lymfocyten hetgeen er dus weer op wijst dat het virus op een wellicht indirecte manier het immuunsysteem stimuleert.

Verder onderzoek naar de perivasculaire ontsteking in de vaten werd beschreven in hoofdstuk 5. Door gebruik te maken van het allogene aortatransplantatie model kon worden aangetoond dat infectie met levend CMV leidde tot optreden van een ontstekingsreactie in de adventitia. Deze ontstekingsreactie was aanwezig op dag 7 maar was op dag 28 na transplantatie nog in sterkte toegenomen. Het effect was vooral aanwezig voor het aantal $\mathrm{CD}_{4}{ }^{+}$en $\mathrm{CD}_{8}{ }^{+} \mathrm{T}$-lymfocyten in de perivasculaire ruimte. Ook werden er in de CMV-geïnfecteerde groep significant meer cellen gevonden die interleukine- 2 receptor positief waren dan in de controle groep. Dit betekent dus dat er een activatie had plaats gevonden van de aanwezige T-lymphocyten. Onderzoek naar de aanwezigheid van MHC-II antigenen op het oppervlak van cellen toonde aan dat dit significant meer was in de getransplanteerde aorta's van geïnfecteerde dieren dan van de controle dieren. Ook werd er meer expressie van de adhesiemolecule ICAM-1 gevonden op de cellen van de CMV geïnfecteerde aorta's dan van de controle aorta's hetgeen ook weer aantoont dat CMV infectie leidt tot activatie van cellen, in dit geval endotheelcellen in het getransplanteerde orgaan. Voor al deze virus-geïnduceerde effecten is actieve infectie noodzakelijk. Injectie van geïnactiveerd virus immers leidde niet tot de opregulatie van de influx van ontstekingscellen en ook niet tot activatie van de aanwezige lymfocyten of endotheelcellen.

Uit de resultaten beschreven in voorgaande hoofdstukken is duidelijk naar voren gekomen dat verschillen in weefselantigenen tussen donor en ontvanger van belang zijn voor het optreden van een transplantatie-geassocieerd arterioscleroseproces. Om dit verder uit te zoeken is onderzoek verricht in rattenstam-combinaties waarbij er ofwel een verschil in de MHC-klasse I antigenen aanwezig was, ofwel een verschil in de MHC- klasse II antigenen (hoofdstuk 6). Voor het MHCklasse I verschil werd de ratten-combinatie: donor: Lewis en Rp rat als ontvanger gebruikt; voor het MHC-klasse II verschil werd de Wag/Rij rat als donor gebruikt en de Rp rat als ontvanger. De aortatransplantatie experimenten werden verder op dezelfde wijze uitgevoerd als bij de eerdere beschreven BN-Lewis experimenten. De ratten werden bestraald met 5 Gray totale lichaamsbestraling en infectieus RCMV werd via intraperitoneale route geïnjecteerd. Op diverse tijdstippen na transplantatie werden de getransplanteerde vaten onderzocht op aanwezigheid van een ontstekingsreactie en op de vorming van een neointima. Uit de resultaten van dit onderzoek blijkt dat de influx van monocyten/macrofagen versterkt is doch dat dit voornamelijk gebeurt in de ratten met een verschil in MHC-klasse I antigenen. Dit effect is echter slechts waarneembaar in de vroege fase (dag 7) na de transplantatie. In de rattencombinatie met een verschil in MHCklasse II leidt CMV infectie tot een toename in de influx van T-lymfocyten in de adventitia. Dit 
fenomeen is vooral op dag 28 na transplantatie waarneembaar. Alhoewel de totale ontstekingsreactie sterker aanwezig is in de rattencombinatie met een MHC-klasse II verschil is toch het CMV effect op de neointimavorming in de rattencombinatie met een MHC-klasse I verschil het meest prominent aanwezig. Dit zou er op kunnen wijzen dat voor het optreden van een CMV effect verschillen tussen donor en ontvanger in de MHC-klasse I van groter belang zijn dan verschillen in de MHC-klasse II. Dat CMV ook een invloed heeft op de influx van de monocyten/macrofagen in deze rattenstam-combinatie doet vermoeden dat er een correlatie bestaat tussen de aanwezigheid van monocyten/macrofagen in de perivasculaire ruimte en de vorming van een neointima. Of de productie van groeifactoren door deze monocyten/macrofagen ook verantwoordelijk zijn voor de proliferatie van de gladde spiercellen is vooralsnog onbekend maar zou een verklaring kunnen zijn voor de correlatie tussen deze beide effecten.

Tot slot is ook onderzoek verricht naar de bijdrage van een CMV infectie op de chronische afstoting in een niertransplantatiemodel. Omdat er aanwijzingen waren dat ischemie een rol kan spelen in de pathogenese is dit onderzoek toegespitst op enerzijds de bijdrage van CMV aan de pathogenese van de chronische afstoting en anderzijds de rol van ischemie op dit proces. Om dit uit te zoeken werden niertransplantaties verricht in 4 groepen ratten. De eerste groep bestond uit dieren die geen $\mathrm{CMV}$ infectie ondergingen en waarvan de nieren geen verlengde koude ischemie ondergaan hadden. De tweede groep werd met CMV geïnfecteerd. De derde groep werd niet geïnfecteerd maar hiervan werden de nieren aan een verlengde koude ischemie onderworpen. De vierde groep onderging beiden (CMV infectie en verlengde koude ischemie). De resultaten van dit onderzoek zijn beschreven in hoofdstuk 7. Hieruit blijkt dat CMV infectie leidde tot een toename van de ontstekingsreactie, van de neointimavorming en van de glomerulaire sclerose. Verlengde koude ischemie leidde tot een toename van de schade en van de ontstekingsreactie in de getransplanteerde nieren van de geïnfecteerde dieren. Immunohistochemische kleuringen van de nieren die verwijderd waren op dag 10 na transplantatie toonden aan dat er toegenomen perivasculaire infiltraten, hoofdzakelijk bestaande uit monocyten en macrofagen, evenals een toegenomen interstitiële influx van $\mathrm{CD}_{g}{ }^{+} \mathrm{T}$-lymfocyten aanwezig waren in de CMV geïnfecteerde dieren. Verlengde koude ischemie alleen leidde tot een versterkte perivasculaire en interstitiêle ontstekingsreactie terwijl in de nieren van dieren die zowel een CMV infectie ondergaan hadden als onderworpen waren aan een verlengde koude ischemie de intensiteit van de ontstekingsreactie veel sterker was. In deze groep was de influx van $\mathrm{CD}_{4}{ }^{+}$en $\mathrm{CD}_{8}{ }^{+}$T-cellen, NK-cellen en monocyten/macrofagen sterk toegenomen, hetgeen wijst op een synergisme tussen schade tengevolge van de CMV-infectie en de schade tengevolge van de verlengde koude ischemie. In deze zelfde ratten was ook activatie van het endotheel waarneembaar op dag 60 na transplantatie.

Samengevat kan men stellen dat in dit proefschrift bevestigd wordt wat door eerdere onderzoeken is vastgesteld, met name dat CMV-infectie leidt tot een versterking van de transplantatiegeassocieerde arteriosclerose.

Het effect van het virus is waarneembaar enerzijds door een toename in de influx van ontstekingscellen in de perivasculaire ruimte en anderzijds door een toename in de neointimavorming. De virusinfectie leidt niet alleen tot een toename in het aantal monocyten/macrofagen en T-lymfocyten $\left(\mathrm{CD}_{4}\right.$ en $\mathrm{CD}_{8} \mathrm{~T}$-lymfocyten) maar ook tot een activatie van aanwezige cellen (zoals aangetoond door (toegenomen) aanwezigheid van interleukine-2 receptor, MHC-klasse 
II antigenen en ICAM-1). Voor het effect van het virus is het noodzakelijk dat er voldaan wordt aan twee voorwaarden: ten eerste levend (actief) virus, ten tweede: allogene orgaantransplantatie. Het feit echter dat geen of nauwelijks virus aangetroffen kon worden in het getransplanteerde orgaan wijst er op dat ofwel minimale (ondetecteerbare) hoeveelheden virus verantwoordelijk zijn voor dit chronische effect ofwel dat een eenmalige actieve infectie, elders in de gastheer, in staat is om een chronisch proces op gang te brengen en dit in afwezigheid van (infectieus) virus in het getransplanteerde orgaan zelf. Diverse andere factoren, waaronder initiële endotheelschade en koude ischemie, spelen eveneens een rol in het proces en versterken dit proces. 


\section{LIST OF PUBLICATIONS FOR THIS THESIS}

Li F., Grauls G., Yin M. and Bruggeman C. A. Correlation between the intensity of cytomegalovirus infection and the amount of perivasculitis in aortic allografts. Transplant International 1996; 9:S340-S344

Li F., Grauls G., Yin M. and Bruggeman C. A. Initial endothelial injury and cytomegalovirus infection accelerate the development of allograft arteriosclerosis. Transplantation proceedings $1995 ; 27: 3552-3554$

Li F., Grauls G., Dam J. G. van, Yin M. and Bruggeman C. A. Cytomegalovirus infection enhances the perivascular inflammatory reaction in transplanted aortic allografts. Cardiovascular Engineering 1997; 2:207-214

Li F., Yin M., Dam J. G. van, Grauls G., Rozing J. and Bruggeman C. A. Cytomegalovirus infection enhances the neointima formation in rat aortic allografts. Effect of major histocompatibility complex class I and class II antigen differences. Transplantation 1998; 65:12981304

Bruggeman C. A., Li F. and Stals F. S. Pathogenicity of cytomegalovirus infection: animal models. Scandinavian Journal of Infectious Disease Suppl 1995; 99:43-50

Yin M., Li F., Dam J. G. van, Grauls G. and Bruggeman C. Effects of cytomegalovirus infection and prolonged cold ischemia on chronic rejection of rat renal allografts. I. Functional and morphological changes.Submitted. 


\section{ACKNOWLEDGMENTS}

This thesis would not have been possible without the help and support from many individuals. I would like to take this opportunity to express my sincere gratitude and appreciation to:

Professor Cathrien Bruggeman for offering me the opportunity to study in the Department of Medical Microbiology, for your continuous guidance, support and encouragement throughout this study, and for completing some of my unfinished work and ultimately this thesis after my leaving for the US. I am indebted also to you for providing help with many non-scientific matters.

Gert Grauls for your technical advice and support, for creating a pleasant working atmosphere, for introducing me to other laboratories or personnel when I needed, for your contribution to the studies and this thesis, and for your friendship.

Wil Mullers for your great technical help, especially for your expertise on computer graphing and layout of this thesis.

Joanne van Dam and Fia Claus for your nice collaboration and for all kinds of help on and off work.

I deeply thank Professor Gauke Kootstra and Mr. Ton van de Bogaard for your great support both in my work and in our family life in The Netherlands.

Last but not least, I wish to express my gratitude to my family members. My husband, Ming, for his love, continuous support and encouragement throughout the years to finish this thesis. My parents and parents-in-law for their encouragement. My daughter, Hannah, for giving me great joys in life during those meaningful days. 


\section{CURRICULUM VITAE}

Fengling $\mathrm{Li}$ was born in Heilongiiang, China on November 6, 1962. She attended the Harbin Medical University in 1979 and graduated in 1984. From 1984 to 1992, she worked as a resident and then an attending physician in the Department of Obstetrics and Gynecology, the Second Teaching Hospital of Harbin Medical University, Harbin, China. From August 1993 to July 1996, she was a PH.D student in the Department of Medical Microbiology (Chairman, Prof. C. A. Bruggeman), Maastricht University, Maastricht, the Netherlands. From 1996 to present, she is a research associate in the Department of Medicine, University of North Carolina at Chapel Hill, North Carolina, the United States of America. 
